\title{
CHRONOLOGY IN THE TIMELINE OF HISTORICAL KNOWLEDGE
}

Collective monograph

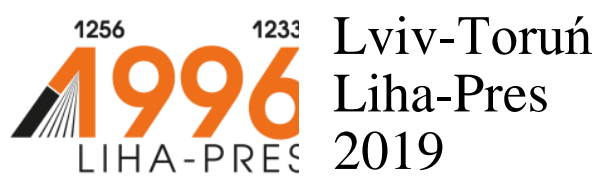




\section{Reviewers:}

Prof. nadzw., dr hab. Stanistaw Kunikowski, Rektor of Cuiavian University in Wloclawek (Republic of Poland);

Prof. dr hab. Joanna Marszałek-Kawa, Uniwersytet Mikołaja Kopernika w Toruniu / Nicolaus Copernicus University (Republic of Poland).

Chronology in the timeline of historical knowledge : collective monograph / V. M. Andryeyev, M. D. Haliv, H. Z. Hrytsenko, V. I. Ilnytskyi, etc. - Lviv-Toruń : Liha-Pres, 2019. - $160 \mathrm{p}$.

ISBN 978-966-397-138-4

Liha-Pres is an international publishing house which belongs to the category „C" according to the classification of Research School for Socio-Economic and Natural Sciences of the Environment (SENSE) [isn: 3943, 1705, 1704, 1703, 1702, 1701; prefixMetCode: 978966397]. Official website - www.sense.nl. 


\section{CONTENTS}

VIKTOR PETROV (1894-1969): THE SCYTHIAN ISSUE

IN THE SCIENTIFIC HERITAGE OF SCIENTIST

Andryeyev V. M.

.1

THE METHODOLOGY OF THE RESEARCH

OF EPISTEMOLOGICAL FOUNDATIONS OF UKRAINIAN

HISTORICAL AND PEDAGOGICAL NARATIVE

(MID-NINETEENTH - LATE TWENTIETH CENTURY)

Haliv M. D 22

THE CREATIVE INTERACTION OF BELARUSIAN

AND UKRAINIAN CULTURAL LEADERS AT THE AGE

OF NATIONAL REVIVAL

Hrytsenko H. Z

38

THE SOURCES TO THE HISTORY OF FUNCTIONING

OF THE UKRAINIAN LIBERATION MOVEMENT

IN THE CARPATHIAN REGION OF THE OUN (1945-1954)

Ilnytskyi V. I.

PEASANTRY AS THE MAIN MILITARY FORCE DURING

UKRAINIAN REVOLUTION PERIOD 1917-1921

Masnenko V. V. .88

THE POLICE OF THE SEVERAN DYNASTY

TOWARDS CHRISTIANITY

Petrechko O. M. 104 


\section{UKRAINIAN-POLISH POLITICAL RELATIONS \\ IN THE CONTEXT OF OPPOSING IMPERIAL \\ ENCROACHMENTS FROM RUSSIA}

Sytnyk O. M.

HOW IMPERIAL HISTORIANS BECAME NATIONAL:

THE EXAMPLE OF ONYKII MALYNOVSKYI

Yaremchuk V. P. 135 


\section{VIKTOR PETROV (1894-1969): THE SCYTHIAN ISSUE IN THE SCIENTIFIC HERITAGE OF SCIENTIST}

\section{Andryeyev V. M.}

\section{INTRODUCTION}

Viktor Platonovych Petrov was born on the $10^{\text {th }}\left(23^{\text {rd }}\right)$ day of October, 1894 in the city of Katerynoslav. He studied at gymnasiums in Odessa and Chełm. After graduating from Chełm Gymnasium in 1913, he entered Kyiv University named after Saint Volodymyr, Faculty of History and Philology (Department of Slavic-Russian Philology). After graduating from the university, with a silver medal, a capable young scientist stayed at the department of the Russian language and literature as a professor's fellow. (1917-1920). ${ }^{1}$

All his life, starting from 1919, not counting a forced break in 1942-1956, V. Petrov devoted himself to the Academy of Sciences of Ukraine. He was one of the first scientists of the All-Ukrainian Academy of Sciences, working actively and fruitfully in various academic establishments. Thus, in 1919-1920 he was a secretary of the Commission for the Compilation of the Historical Dictionary of the Ukrainian Language. In January 1920 he started working as a research assistant and later as a secretary (1923-1927) and as a head (1927-1933) of the Ethnographic Commission of Academy of Sciences of the USSR, and edited various editions of the commission. In 1930 he received a $\mathrm{PhD}$ in Philology for his monograph about Kulish ${ }^{2}$. From 1933 V. Petrov held a position of research assistant and from 1939 he was a head of the Prefeudal and Feudal Archeology of the Union of Institutions of Material Culture (since 1934 the Institute of History of Material Culture, which was subsequently reorganized into the Institute of Archeology of the Academy of Sciences of the Ukrainian Soviet Socialist Republic). In February 1941 the scientist became director of the newly established Institute of Ukrainian Folklore of the Academy of Sciences of the Ukrainian Soviet Socialist Republic. This period of his research activity is represented by quite considerable scientific work - about 100 works ${ }^{3}$.

\footnotetext{
${ }^{1}$ Автобіографія Віктора Платоновича Петрова / Вступне слово та примітки В. Корпусової. Слово $i$ час. 2002. № 10. Ст. 51-52.

${ }^{2}$ Петров В.П. Пантелеймон Куліш у 50-ті роки. Життя, ідеологія, творчість. Монографія. Збірник Історико-Філологічного Відділу Украӥнської Академї Наук. № 88. Київ, 1929. 572 ст.

3 Автобіографія Віктора Платоновича Петрова. Ст. 51-52; Петров В.П. Язык. Этнос. Фольклор. Автореферат по совокупности работ на соискание ученой степени кандидата филологических наук. К.,
} 
During The Eastern Front of World War II, Viktor Platonovych served in the ranks of the Red Army, was an intelligence operator in the enemy rear area. In 1945-1949 he worked in the sphere of Ukrainian emigration in Bavaria. He became one of the founders of the Ukrainian Art Movement (UAM), editor of literary periodicals, teacher at the higher educational establishments of Ukrainian emigration (Ukrainian Free University, The Theological Academy of Ukrainian Autocephalous Orthodox Church, Ukrainian Technical and Economic Institute), and worked extensively scientifically. Formally, until 1950, V. Petrov served in the Ministry of Foreign Trade of the USSR as a research assistant. In 1950-1956, after a mysterious return from Germany, this scientist worked as a researcher at the Institute of Material Culture History of the Academy of Sciences of the USSR in Moscow, and from December 1956 until his death (June $08^{\text {th }}$, 1969) he worked at the Institute of Archeology of the Academy of Sciences of the the Ukrainian Soviet Socialist Republic ${ }^{4}$.

Petrov's first archaeological research started in the pre-war years and was related to the Trypillian culture. The scientist discovered and interpreted the Late Trypillia monuments of the so-called Horodskyi type. At the same time, he was one of the first who drew attention to the culture of "burial fields", discovered by the prominent Ukrainian archaeologist V. Khvoyko, later known as Zarubinets culture (III century BC - II century AD) and Chernyakhov culture (III - V century AD). In general, V. Petrov made considerable efforts to study and introduce the heritage of his predecessors, first of all V. Khvoyko, into the scientific circulation. In the late 1930s, he initiated the creation of a group of researchers to study these cultures which were directly related to the issue of Slavic ethnogeny. According to the plan of the scientist the result of large-scale work was to become a collective work in several volumes, which was to be published by the Institute of Archeology. The war prevented the publishing of the materials worked out and prepared for printing by a team of scientists led by V. Petrov. But all the achievements of this group of researchers became the basis of a series of volumes published in the postwar years from the series "Materials and Studies in Archeology of the USSR". After the war, the scientist, while studying the Chernyakhov culture, carefully studied the settlements of the early Slavic period of VI - VIII centuries, as well as the monuments of Kyiv Rus ${ }^{5}$.

1966. 62 ст.; Віктор Платонович Петров. Украйнський історичний журнал. 1969. № 9. Ст. 158 ; Березовський I. Визначний дослідник. Народна творчість та етнографія. 1970. № 6. Ст. 57-58; Франко 3. Він не встиг написати мемуарів. Київ. 1984. № 12. Ст. 84-85; Франко З. Людина покликання та обов’язку. Літературна Україна. 1984. 1 листопада. № 44 (4089). С. 5 тощо.

4 Толочко П.П. Віктор Петров - дослідник українського етногенезу. Петров В. Походження українського народу. К.: МП «Фенікс», 1992. Ст. 3-4; Блокінь С. Довкола таємниці. Ibid. Ст. 165-192.

5 Толочко П.П. Віктор Петров - дослідник українського етногенезу. Ibid. Ст. 4; Його ж. Слово про В.П. Петрова - видатного українського археолога. Проблеми походження та історичного розвитку слов'ян. Збірник наукових статей присвячений 100-річчю з дня народження Віктора Платоновича Петрова. Київ-Львів: «РАС», 1997. Ст. 6. 
V. Petrov started studying the Scythology issues in the 1940s. The history of the Scythians was in the range of his scientific interests in connection with the study of the Ukrainian and Slavic ethnogeny. The Scythian plot was reflected both in the special works of the researcher and in the corresponding sections of his monographs devoted to the origin of the Ukrainian people and Slavs. He outlined the basic principles of his original concept of the history and ethnogeny of the Scythians in a lecture "The origin of the Ukrainian People" (1947), which was published only after his death in $1992^{6}$.

In the future, the researcher developed his views in a number of works, such as "Scythian Genealogical Legend", "From the Ethnonymy and Toponymy of the Northern Black Sea"8, "The Ancient Slavs and Their Origins (Before the Issue of Slavic Ethnogeny)"," "The Scythians. Language and Ethnicity" "Ethnogeny of the Slavs. Sources, state of development and problems" ", etc. Thus, it may be affirmed that the Scythian theme occupied a prominent place in the scientific work of V.Petrov, bit was not the main one. However, with rare exceptions, researchers of the scientist's life and work have bypassed this significant component of his intellectual biography ${ }^{12}$. So in this paper we will try to correct this omission of modern historiography.

The methodological basis of the scientist's research was the theory of academician M. Marr. In the 1930s, working at the Institute of Material Culture, V. Petrov, like many other scientists, stood for glotogonic theory that emphasized the autochthonous development of peoples and opposed the migrations concepts of the Western scholars. The basis of theory established a postulate that linguistic genesis proceeded by mixing and

\footnotetext{
${ }^{6}$ Петров В. Походження українського народу.

7 Петров В.П., Макаревич М.Л. Скифская генеалогическая легенда. Советская археология. 1963. № 1. Ст. 20-31.

${ }^{8}$ Петров В.П. Из этнонимики и топонимики Северного Причерноморья. Материалы по археологии Северного Причерноморья. Одесса, 1962. Вып. 4. Ст. 230-238.

9 Петров В. Давні слов'яни та їх походження (До проблеми слов'янського етногенезу). Украӥнський історичний журнал. 1963. № 4. Ст. 36-44.

${ }^{10}$ Петров В. Скіфи. Мова і етнос. К., 1968. 149 ст.

${ }^{11}$ Петров В. Етногенез слов'ян. Джерела, стан розвитку і проблематика. К., 1972. 214 ст.

12 Андрєєв В. Віктор Петров: Нариси інтелектуальної біографії вченого. Дніпропетровськ: Герда, 2012. Ст. 256-292; Його ж. Скіфська генеалогічна легенда в інтерпретаціях Віктора Петрова. Південний архів. Історичні науки. Херсон: Вид-во ХДУ, 2009. Вип. 31/32. Ст. 15-29; Його ж. Віктор Петров: «скіфський сюжет» інтелектуальної біографії. Украӥнський історичний журнал. 2010. № 2. Ст. 190-202; Його ж. Віктор Петров: вирішення проблеми скіфської мови у науковому спадку вченого. Гуманітарний журнал.

Дніпропетровськ, 2010. Вип. 3/4 (літо-осінь). Ст. 30-38; Його ж. Скіфська державність у працях В. Петрова: політичний та етнічний аспекти. Література та культура Полісся. Ніжин: Вид-во НДУ ім. М. Гоголя, 2011. Вип. 63. Ст. 92-98; Його ж. Антична доба в історії України в контексті «теорії епох» В. Петрова. Наукові праиі. Історія. Миколаїв: Вид-во ЧДУ ім. Петра Могили, 2012. Вип. 195 (Т. 207). Ст. 70-74; Andryeyev V., Karjaka O. Problems of the Baltic-Slavic Linguistic unity and Ancient Prussian language in the scientific heritage of Victor Petrov. Східноєвропейський історичний вісник. Вип. 10. 2019. Ст. 8-17.
} 
"crossing" languages. From this it turned out that all peoples were formed autochthonously. According to M. Marr's teachings, language, culture, race, religion, etc. are historical categories, and cultures and languages, including ancient ones, were not merely mixed but also class in nature ${ }^{13}$. In addition, Marr has strongly advocated interdisciplinary research that should combine the efforts of linguists, archaeologists and other humanitarians. The new complex science was called "Japhetic theory"14. V. Petrov also insisted on solving the issues of ethnogeny of any people, including the Scythians, applying a comprehensive approach with the use of data of linguistics, archeology, history and ethnography. As a versatile scientist, he successfully applied multidisciplinary approaches in his own research $^{15}$.

In the 1950s and 1960s, while studying the Scythians, V. Petrov applied Marr's approaches in his ethnogenetic studies, at the same time warning against the uniquely simplified and general interpretation of the theoretical works of M. Marr and his followers ${ }^{16}$. According to the scientist, the purpose of historical studies of ethnos is to reproduce the peculiarities of the condition of a certain humanity in the presence of all sources - language, culture, socio-economic system objectively and completely and to determine its position in the genetic sequence: "Preference should not be given to autochthonism and not migrations as such, but historicism above all"17.

\section{The Issue of the Scythian language in the research of V. Petrov}

First of all, addressing the issue of the origin of the Scythians, the scientist considered the issue of the Scythian language. For V. Petrov, as a linguist, the Scythian period was the starting point, because precisely at that time the written sources provided material of specific historical content for the first time, i.e. preserved language was defined in time and space. Linguistic analysis in his work covers categories of names referring to the names of the Scythian deities, tribes and hydronyms of Scythia according to ancient sources ${ }^{18}$. V. Petrov's researches are based on the wide involvement of Indo-European language material, which expands the range of etymological parallels for the names of the Scythian era and

13 Юсова Н. Становлення радянської етногенетики (в світлі глотогонічної теорії М. Марра). Проблеми історії України: факти, судження, пошуки. Міжвідомчий збірник наукових праџь. Вип. 15. К.: Інститут історії НАН України, 2007. Ст. 172-174.

${ }^{14}$ Ibid. Ст. 170-171.

15 Брайчевський М.Ю. В.П. Петров - учений-універсал. Археологія. 1990. № 3. Ст. 95-100.

${ }^{16}$ Юсова Н. Становлення радянської етногенетики. Ст. 176.

${ }^{17}$ Петров В. Етногенез слов'ян. Ст. 118.

${ }^{18}$ Петров В. Скіфи. Мова і етнос. Ст. 50-114. 
"breaks the monopoly of Scythian-Iranian correspondences", characteristic of the researches of the previous time ${ }^{19}$.

According to the scientist, modern Scythology went a wrong way categorically accepting the Iranian language of the Scythians. Thus, examining the historiography of issue, he analyzed the researches of his predecessors, beginning with K. Mullenhof and W. Miller (founders of the study of the Scythian language, who established the Iranian language of the Scythian world). The researcher believed that the Iranian-Ossetian concept of Mullenhof-Miller, which originated in the second half of the nineteenth century $^{20}$, was supported by the following generations of researchers (F. Justi, V. Tomaschek, I. Markvart, M. Vasmer, V. Abaev, J. Harmatta, L. Zgusta) and acquired the value of the historiographic norm, and the thesis of the Iranian language of the Scythians was transformed into a principle of methodology. Most archaeologists unconditionally accepted this position. But this approach was considered false by the scientist, because "it does not take into account the question of studying the preserved language whose ethnic is unknown." In his view, these researchers ignored this fact and considered the language of the ancient population of the Dnieper as a predetermined. Thus, "the unknown was proclaimed known," and the contingent assumption, "which was yet to be proved, transformed into an unbreakable dogma." Thus, in Scythology, a kind of "Pan-Iranism" was established. Thus, the famous Iranian scientist V. Abaev proclaimed: "Anything that is not explained from the Iranian, in most, is not explainable at all ${ }^{21} "$.

However, none of the following researchers dared to point out the incorrectness of similar statement of a question from Petrov's point of view. He also believed that the instructional technique, "based on the principle of monolingual convergence, explaining the preserved Scythian and Sarmatian language with the help of Iranian", was clearly unacceptable. The scientist insisted that the comparative-historical method requires "the attraction of all those languages that are part of the examined linguistic community", and with the help of monolingual Iranian-Ossetian analogies it is impossible to prove that "the Scythians are Iranians and that they are the direct historical ancestors of the Ossetians"22.

\footnotetext{
19 Петраускас О.В. Балто-слов'янські відносини за роботами Віктора Платоновича Петрова. Проблеми походження та історичного розвитку слов'ян. Збірник наукових статей присвячений 100-річчю з дня народження Віктора Платоновича Петрова. Київ-Львів: «РАС», 1997. Ст. $20-21$.

${ }^{20}$ Müllenhoff K. Uber die Herkunft und Sprache der pontischen Skithen und Sarmaten. Monatsberichte der K. Preussischen Akademie der Wissenschaften. 1866. S. 549-576; Міллер В. Осетинские этюды. Ч. 1-3. M., 1881-1887.

${ }^{21}$ Абаев В.И. Осетинский язык и фольклор. М.; Л., 1949. Т. І. Ст. 37.

22 Петров В. Скіфи. Мова і етнос. К., 1968. Ст. 6-33; Петров В. Етногенез слов'ян. Джерела, стан розвитку і проблематика. К., 1972. Ст. 207-208.
} 
In his works, the scientist consistently proved that the Scythian language is not Iranian and "especially not Pro-Ossetian". In his opinion, it was an independent language, one of the Eastern Indo-European languages, which shows "the closest affinity with the languages of the adjacent territories, according to its geographical location: in the East Indo-Iranian, in the North - with the Baltic and in the South-West - with the Thracian",23.

In the 1940s-1960s, as today, most scholars acknowledged the Iranian language of the Scythians, and similar attempts of V. Petrov to refute the points of view established in historiography, required a remarkable scientific courage and self-righteousness. After all, any attempts of individual scientists to violate the "Iranism" of the Scythians received a rather sharp response from the monolithic groups of Scythologists and Iranists. Thus, for example, only for doubts about the existence of "Iranian unity" 24 , the leading Ukrainian archaeologist E. Chernenko became the object of criticism of colleagues for the fact that he "without any motivation proclaims the existence of Iranian unity as "problematic". So, the majority of the scientific community remained at their former positions and did not share the views of V. Petrov.

However, the Ukrainian archaeologist, M. Brichevskyi, supported the findings of the researcher. Thus, he pointed out, referring to V. Petrov's research that the existing statement that the Scythians spoke the Iranian language was not confirmed; he affirmed that the Scythians were a separate Indo-European people with their own language, which had much in common with the languages of the Iranians, Thracians, Balts, Slavs and Indo-Aryans. Following V. Petrov, he noted that the proclamation of the Scythians as "Iranians" was based on the use of a false methodology: Accepting the Iranian hypothesis a priori, the researchers looked for comparative material for interpreting the Scythian glosses and onomastic names only in the languages of the the Iranian group ${ }^{25}$.

Therefore, V. Petrov became a harbinger of new searches in the language archaism of Prypontida ${ }^{26}$ in the native Scythology, as he raised doubts about the postulate of the Scythian' was the Iranian language ${ }^{27}$. The

\footnotetext{
${ }^{23}$ Петров В. Етногенез слов'ян. Ст. 207-209.

${ }^{24}$ Яценко И.В., Раевский Д.С. Некоторые аспекты состояния проблемы (обзорная статья). Круглый стол «Дискусионные проблемы отечественной скифологии». Народы Азии и Африки. 1980. № 5. Ст. 105).

25 Брайчевський М.Ю. «Русские» названия поргов у Константина Багрянородого. Земли Южной Руси в $I X-X I V$ вв. К., 1985. Ст. 22-23.

${ }^{26}$ Корпусова В.М. В.Петров (Домонтович): етногенетика як свобода самовиявлення. Слово $i$ час. 2002. № 10. Ст. 24.

${ }^{27}$ Петров В. Походження українського народу. К. МП: «Фенікс», 1992. 192 ст.; Петров В. Скіфи. Мова і етнос. К., 1968. 149 с.; Петров В. Етногенез слов'ян. Джерела, стан розвитку і проблематика. К., 1972. 214 ст.
} 
researches of the Indo-European linguistics later came to the conclusions similar to scientist's opinions.

With his new approaches to seemingly resolved issues, V. Petrov stimulated further development of the Scythology and creation of new approaches and theories. Thus, the Indo- Aryan hypothesis demonstrating the idea of resettlement of Indo-Aryan peoples in the East Pryasovia, had been developing in 1920s-1940s, but was finally stated and formulated in the works of the prominent Moscow linguist O. Trubachov in 1970s-1990s. The researcher, localizing the ancestral homeland of IndoIranian peoples in the Eastern Europe, considered that after the division of this community into Indo-Aryan and Iranian languages, a part of IndoAryan peoples continued to live on the south of the Eastern Europe and was assimilated with the Scythians spoke Iranian language. Despite of assimilation, the Indo-Aryan language layer, determined by O. Trubachov based on the materials of onomastics of the North region of the Black Sea, toponymics, etc., was sufficiently noticeable on the general Iranian background, showing language diversity of peoples living in Scythia ${ }^{28}$.

Moscow scientist-ironist L. Lelekov ${ }^{29}$ and Leningrad researcher L. Klein ${ }^{30}$ continued the work aimed at determination of Indo-Aryan component and its role in the formation of the world of Scythians and Sarmatians. They developed an idea about the presence of Indo-Aryan elements in the Scythian culture. Thus, researchers consider that a thesis that the Scythian cultural morphology is more similar with the Indo-Aryan and less similar with Iranian, causes no doubts ${ }^{31}$. Besides L. Klein insists on the special, "bypassing the Iranians", similarity of the Scythians with the Indo-Aryan people. In his opinion, the sources of similarity of the

28 Трубачов О.Н. О синдах и их языке. Вопросы языкознания. 1976. № 4. Ст. 39-63; Його ж. Лингвистическая переферия древнейшего славянства. Индоарийцы в Северном Причерноморье. Bonpocbl

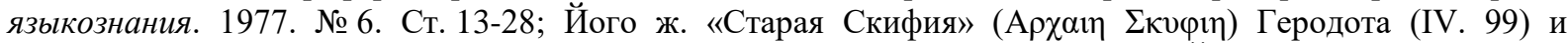
славяне. Лингвистический аспект. Bопросы языкознания. 1979. 4. Ст. 29-45; Його ж. Выступление на круглом столе «Дискусионные проблемы отечественной скифологии». Народы Азии и Африки. 1980. № 5. Ст. 117-118; Його ж. Indoarica в Северном Причерноморье: Источники. Интерпретация. Реконструкция. Bопросы языкознания. 1981. № 2. Ст. 3-21; Його ж. Indoarica в Скифии и Дакии. Этногенез народов Балкан и Северного Причерноморья. М., 1984. Ст. 148-152; Його ж. Этногенез и культура древнейших славян. Лингвистические исследования. М.: Наука, 2003. Ст. 74-75, 165-166 тощо.

${ }_{29}$ Лелеков Л.А. R. Girshman. L'Iran et la migration des Indo-Aryens et des Iranians. Народы Азии и Африки. 1978. № 5. Ст. 225; Його ж. Выступление на круглом столе «Дискусионные проблемы отечественной скифологии». Народы Азии и Африки. 1980. № 5. Ст. 125-128; Його ж. Проблемы индоиранских аналогий к явлениям скифской культуры. Скифо-сибирское культурно-историческое единство. Кемерово, 1980. Ст. 122-123 тощо.

${ }^{30}$ Клейн Л.С. Откуда арии пришли в Индию. Вестник Ленинградского университета. 1980. Вып. 4 (20). Ст. 35-40; Його ж. Третья гипотеза о происхождении скифов (Выступление на круглом столе «Дискусионные проблемы отечественной скифологии»). Народы Азии и Африки. 1980. № 6. Ст. 72-74; Його ж. Индоарии и скифский мир: общие истоки идеологии. Народы Азии и Африки. 1987. № 5. Ст. 63-82 тощо.

31 Лелеков Л.А. Выступление на круглом столе «Индоарии и скифский мир: общие истоки идеологии». Народьл Азии и Африки. 1987. № 5. Ст. 86. 
Scythians and Indo-Aryan people relate not to the first, as it had been considered before, but to the second millennium $\mathrm{BC}^{32}$.

Besides, investigating ethnogeny of Slavs and in this connection binding the Scythians, Slavs Ukrainians from the point of view of language and culture, V. Petrov expressed some opinions that in some degree conform with proofs of other scientists (linguists and anthropologists), that the population of Ukraine absorbed the Scythian understratum ${ }^{33}$.

\section{The Issue of Ethnogeny of the Scythians}

Certainly, the most important and at the same time controversial aspect of the Scythian issue was the issue of ethnogeny of the Scythians and Scythian culture. In 1940-1960 in his "Scythian Studios" V. Petrov insisted on the autochthony of the Scythian population in the territory of Ukraine. He wrote: "They (Scythian - A.B.) is a ethnogenetic product of development of previous (Post-Trypillian, Pre-Scythian) period, next, late period of deformation of aboriginal people, that had been formed in Ukraine in Usativsko-Horodske Post-Trypillia"34. Therefore, the scientist firmly stood for aboriginal-Ukrainian origin of Scythians, although, in his opinion, the imperial Scythian had been iranized due to a long-term staying in Iran. His point of view in this matter organically blended in with discussions of that time between supporters of two hypothesis, which could be called "migrational" and "autochthonous".

"Autochthonous" or "Timber-grave"/"Volga" hypothesis of the origin of the Scythians for the first time was proposed by the Finnish archaeologist A. Tallgren in $1926^{35}$ and developed by Leningrad scientist M. Artamonov (student and supporter of academician M. Marr). In the future this theory was supported by Moscow scythologists B. Grakov, G. Melyukova, O. Krivtsova-Grakova ${ }^{36}$ and others. Supporters of the "autochthonous" theory based their argument on the idea of the Scythians

\footnotetext{
${ }^{32}$ Клейн Л.С. Индоарии и скифский мир: общие истоки идеологии. Ст. 82.

${ }^{33}$ Кухаренко Ю.В. К вопросу о славяно-скифских и славяно-сарматских отношениях. Советская археология. 1954. Т. 19. Ст. 111-120; Зализняк А.А. Проблемы словяно-иранских языковых отношений в древнейший период. Вопросы славянского языкознания. 1962. Вып. 6. Ст. 28-45; Його ж. Контакты между славянами и скифосарматскими племенами. Краткие сообщения Института славяноведения. 1963. Вып. 28. Ст. 3-22; Алексеев Т.И. Этногенез восточных славян по данным антропологии. М., 1973. Ст. 256; Седов В.В. Происхождение и ранняя история славян. М., 1977. Ст. 78-100.

${ }^{34}$ Петров В. Походження українського народу. Ст. 47.

35 Tallgren A. M. La Pondide Prescythique après l'introduction des metaux. Eurasia Septentrionalis Antiqua. Helsinki, 1926. Vol. II. P. 223.

36 Артамонов М.И. К вопросу о происхождении скифов. Вестник древней истории. 1950. № 2. Ст. 44-46; Граков Б. Скіфи. К.: Видавництво АН УРСР, 1947. 93 ст.; Граков Б.Н., Мелюкова А.И. Об этнических и культурных различиях в степных и лесостепных областях европейской части СССР в скифское время. Вопросы скифо-сарматской археологии. М.: Издательство АН СССР, 1954. Ст. 39-93; Кривцова-Гракова О.А. Степное Поволжье и Причерноморье в эпоху поздней бронзы. Maтериаль и исследования по археологии СССР. Вип. 46. М., 1955. С. 155, 161-162; Яценко И.В. Скифия VII - V вв. до н. э. М., 1959. Ст. 17 тощо.
} 
consanguinity with Timber-grave culture bearers of Late Bronze Age. In their opinion timber-grave culture immediately proceeded Scythians one. But there was a difference in opinion among the supporters of "autochthonous" theory. Thus, M. Artamonov considered the timber-grave tribes to be ancestors of Scythians, but the formation of the triad (the concept "Scythian triad" was introduced into scientific parlance in the early 1950's. M. Artamonov, referring to the Scythians of Dnieper, Crimea and Transnistria, noted that they had in common only some types of weapon, trappings and personal outfit, in the decoration of which images of animals were used. For the first time this term was used by B. Grakov and G. Meliukova, after which it became quite widespread in the scientific and popular science literature. The Scythian Triad combines the most striking elements of the material culture of the Scythians - weapon, trappings and animal style in art. This term has become a convenient and understandable "business card" of the Scythians. The Triad during Scythian period existed on a large territory from the Northern Black Sea Region to Tuva and the Minusinsk Hollow). It provided the Scythian culture with a characteristic look. The formation of the triad, from the point of view of M. Artamonov, took place not on a local basis, but during the stay of the Scythians in Western Asia under the direct influence of the culture of the region ${ }^{37}$. According to B. Grakov, it was the Timber-grave culture that underwent significant changes during the transition from the Bronze Age to the Iron Age, and became the basis of a purely Scythian culture, the formation of which was reflected in the "transitional" monuments of the Montenegro and Novocherkassk type ${ }^{38}$.

A special place belongs to the hypothesis of L. Klein. The scientist reasonably believes that he proposed the "truly autochthonous" hypothesis back in 1951. Relying on a wide range of sources, including archeological sources, he insistently proved the thesis about the genetic connection of the Scythians of the king with the bearers of pre-Caucasus Catacomb culture ${ }^{39}$. Despite the fact that the point of view of this outstanding scientist was not recognized by most archaeologists, we mention it for the sake of

\footnotetext{
37 Артамонов М.И. Киммерийцы и скифы (от появления на исторической арене до конца IV в. до н. э.). Л., 1974. Ст. 7, 34.

${ }^{38}$ Граков Б.Н., Мелюкова А.И. Об этнических и культурных различиях в степных и лесостепных областях европейской части СССР в скифское время. Ст. 66, 93; Граков Б.Н. Скифы. М., 1971. Ст. 23.

39 Клейн Л. С. Территория и способ погребения кочевых скифских племен по Геродоту и археологическим данным. Археологический сборник Государственнго Эрмитажа. Вып. 2. Л.., 1961. Ст. 45-56; Його ж. Происхождение скифов царских по археологическим данным. Советская Археология. 1963. № 4. Ст. 27-35; Його ж. Легенда Геродота об азиатском происхождении скифов и нартский эпос. Вестник древней истории. 1975. № 4. Ст. 14-27; Його ж. Проблема «Х». Проблемы скифо-сибирского культурно-исторического единства. Кемерово, 1979. Ст. 18-22; Його ж. Третья гипотеза о происхождении скифов (Выступление на круглом столе «Дискусионные проблемы отечественной скифологии»). Народы Азии и Африки. 1980. № 6. Ст. 72-74; Його ж. Индоарии и скифский мир: общие истоки идеологии. Народь Азии и Африки. 1987. № 5. Ст. 63-82 та ін.
} 
completeness of coverage of the historiography of the issue and "scientific truth".

The "migration" concept was actively supported by the Kyiv archeologists V. Iliinska, O. Terenozhkin and their followers. According to Herodotus, the researchers linked the emergence of Scythian tribes in Eastern Europe with their advance from the deep regions of $\mathrm{Asia}^{40}$. According to O. Terenozhkin there was no succession, neither ethnic nor cultural, between the population of the Northern Black Sea of the preScythian and Scythian period - Scythians came to these territories in the VII century. BC. and they brought with them mostly already formed culture $^{41}$. So, it should be noted that from Herodotus and to modern researchers, the historical version of the emergence of the first Scythians in the Northern Black Sea (their arrival from Asia under the pressure of the Massagetae), traditionally enjoyed great confidence, at least with regard to one of the possible components of the formation of the Black Sea Scythian culture ${ }^{42}$.

However, despite all the incompatibility, at first glance, of the two concepts of ethnogeny of the Scythians, there are certain common features in the views of their adherents. After all, most Scythologists, no matter what concept they adhere to, believe that the formation of Scythians occurred as a result of interaction between local and foreign population. Thus, the differences between the "autochthonists" and the "migrationists" consisted only in a different assessment of the ratio of local and foreign components of the Scythian ethnic group and in determining the territory from which the migration from the East began ${ }^{43}$.

Through the lens of the fact that the Scythian population is autochthonous in the territory of Ukraine, V. Petrov considered the Scythian genealogical legend ${ }^{44}$. His interpretation of this legend was based on a wide range of written sources (writings by Herodotus, Diodorus Siculus, Valery Flack) and archeological sources (decorative art of the Northern Black Sea), analysis of the ethnonyms and toponyms of the Northern Black Sea, and was generally known. In Soviet literature of the 1920s and 1970s, economic-ethnic and ethnic interpretation of the legend

40 Тереножкин А.И. Киммерийцы. К.: Наукова думка, 1976. 220 ст.; Ильинская В.А. Скифы Днепровского лесостепного Левобережья. К.: Наукова думка, 1963; Ильинская В.А. Скифия VII - IV до н. е. К.: Наукова думка, 1983. 378 ст.

${ }^{41}$ Тереножкин А.И. Киммерийцы. Ст. 208.

42 Алексеев А.Ю. Хронография Европейской Скифии VII-IV веков до н.э. Санкт-Петербург: Издательство Государственного Эрмитажа, 2003. Ст. 63.

43 Мурзин В.Ю. Происхождение скифов: основные этапы формирования скифского этноса. К.: «Наукова думка», 1990. Ст. 5.

44 Петров В.П., Макаревич М.Л. Скифская генеалогическая легенда. Ст. 20-31; Петров В.П. Етногенез слов'ян. Ст. 153-159; Його ж. Из этнонимики и топонимики Северного Причерноморья. Ст. 230-238. 
became most widespread. Almost all researchers, although to different degrees and in different ways, argued their positions, asserted the thesis about the prevalence of local agricultural elements over foreign nomadic ones ${ }^{45}$.

Today, V. Petrov's views on the issue of the Scythians' origin appear somewhat outdated. However, according to many reputable Scythologists, the "autochthonous" hypothesis most logically combines archeology, written evidence, and concepts of related sciences without losing its scientific value ${ }^{46}$. Thus, it is safe to say that participation in the formation of the Scythian ethnic group of the autochthonous component is not denied by the majority of scientists, and therefore there is rational kernel in the research of V. Petrov.

\section{The issue of ethno-cultural and economic division of Scythia}

The scientist, arguing the autochthony of the Scythian population, also insisted on the recognition of their ethnic homogeneity throughout the territory of Scythia (Steppe and Forest-steppe). In this regard, he tried to refute the principle of "economic" and "ethnocultural" dismemberment of Scythian tribes - opposition of nomadic Scythians-pastoralists to settled agricultural tribes (forest-steppe - area of non-Iranian agricultural tribes, steppe - tribal zone of Iranian-speaking nomadic pastoralists) ${ }^{47}$. Analyzing the historiography of the issue, V. Petrov emphasizes that in this case we are talking about "historiographic standards" which are "repeated from work to work". Arguing his own point of view, the scientist refers to the new, at that time, research data of the Scythian mounds in the forest-steppe near Boryspil (excavation of V. Iliinska) and notes that the newly discovered monuments are quite identical to the steppe burial mounds of Lower Dnieper, according to signs of burial rite and material culture. Thus, the author concludes that the zonal dismemberment of the Scythian culture is archeologically unsubstantiated, and at that time the cultures of the Steppe and Forest-Steppe were the only ones. In his opinion, “... riders and horsemanship as a social stratum were inherent in the steppe and forest-

45 Варнеке Б.В. Легенди про походження скіфів. Записки Історико-філологічного відділу ВУАН. 1928. № 76; Семенов-Зуссер С.А. Скіфи-кочовники на території Північного Причорномор'я. Наукові записки Харківського Державного педагогічного інституту. Т. І. Харків, 1939. Ст. 170; Артамонов М.И. О землевладении и земледельческом празднике у скифов. Ученые записки ЛГУ. Серия историчеких наук. № 95. Вып. 15. Л., 1948. Ст. 4-5; Граков Б.Н. Скифский Геракл. Краткие сообщения Института истории материальной культуры. Вып. XXXIV. М. -Л., 1950. Ст. 8-9; Його ж. Скифы. М., 1971. Ст. 21-22; Штительман Ф.М. Поселения античного периода на побережье Бугского лимана. Maтериальь и исследования по археологии СССР. № 50. 1956. Ст. 266; Болтенко М.Ф. Herodoteanea. Материаль по археологии Северного Причерноморья. Вып. 3. Одесса, 1959. Ст. 38-55 тощо.

46 Яценко И.В., Раевский Д.С. Некоторые аспекты состояния проблемы (обзорная статья). Круглый стол «Дискусионные проблемы отечественной скифологии». Народы Азии и Африки. 1980. № 5. Ст. 111.

${ }^{47}$ Петров В. Етногенез слов'ян. Ст. 162-163. 
steppe Scythia. So is nomadic life and farming ${ }^{48}$."However, it should be noted here that in fact mounds near Boryspil are now defined by Scythian scholars as "steppe" in accordance with the landscape, because along the Dnieper River there is a steppe strip almost to the breadth of Kyiv, where the mound group referred to by V. Petrov was excavated. In modern Scythology, the infiltration of the steppe equestrian population within the limits of the forest-steppe is beyond doubt, but these monuments left by the steppes are significantly different from the local burial rites.

The researcher's next argument in refuting the concept of the zonalgeographical division of forest-steppe and steppe economic systems is Herodotus' writing of Scythian farmers and Scythian plowmen. According to Herodotus, V. Petrov believed that the Scythian steppe territory around Olbia in the lower reaches of the Dnieper and the Bug was inhabited by Scythian agricultural tribes (Herodotus geōrgoi and aroteres). However, localization of the Scythian farmers caused some difficulties for the researchers, because according to archaeological data in the specified territories in the times of Herodotus and somewhat earlier numerous settled populations were not fixed. This discrepancy between the data of the written source and archaeological realities was later explained by V. Abaiev. Researching the issues of the Scythians geōrgoi, he convincingly proved that the etymology of this ethnonym comes not from the ancient Greek, but from the range of Iranian languages. In his opinion, the term geōrgoi hides not the Greek word with the meaning of "plowmen" but the Greek transfer of the local Scythian name gau-varga. Such an ethnonym finds an exact analogy in the name of another Scythian (Saka) tribe hauma-varga, recorded in ancient Persian cuneiform texts. The researcher suggested to derive the word geōrgoi from Iranian and to consider it an outraged Scythian ethnonym gauvarga, which should be translated "breeders" ("breeders" - varga, "livestock" - gau) 49 or "worshipers (worship) cattle" ${ }^{50}$. Thus, V. Abaiev found out that when Herodotus "Scythians farmer" appeared near the "plowmen", to all questions of the Greek colonists and Herodotus to the locals, as the tribe is called, they received a single answer: gauvarga. In the Greek transmission, this Scythian word was supposed to turn into geōrgoi ${ }^{51}$. So, Herodotus geōrgoi are the same pastoralists and there is no relation to agriculture.

\footnotetext{
${ }^{48}$ Ibid. СТ. 163-164.

49 Абаев В.И. Выступление на круглом столе «Дискусионные проблемы отечественной скифологии». Народы Азии и Африки. 1980. № 5. Ст. 129-130.

${ }^{50}$ Абаев В.И. Геродотовские Skythai Geōrgoi. Избранныле труды. Религия, фольклор, литература. Владикавказ, 1990. Ст. 99-100.

51 Абаев В.И. Выступление на круглом столе «Дискусионные проблемы отечественной скифологии». Ст. 129-130; Його ж. Геродотовские Skythai Geōrgoi. Ст. 99-100.
} 
Trying to prove his own point of view and destroy the concept of zonal-geographical division of economic systems of forest-steppe and steppe, V. Petrov proposed to use ethnographic sources. Thus, in his opinion, in this case it is best to turn to the materials of Central Asia, because the peoples of this region have for a long time kept the remnants of an ancestral organization, which makes it possible to understand the individual messages left by Herodotus about the Scythians. In addition, the scientist also appeals to A. Skalkovskyi ${ }^{52}$ ethnographic studies of the North Black Sea Nogayans. The researcher wrote: "When talking about the Scythians, they usually talk about pastoral and agricultural tribes. They say, "the population of Scythia was divided into nomadic pastoralists and settled agricultural tribes". Such a concept could appear only because of insufficient attention to ethnographic data, which shows that the cattle and blood and economic-property ties have some kind of crossed (here V. Petrov disputes with the famous scytologist I. Yatsenko). Economic activity depended, within the family, on the property of the head of the family. Nomadism or sedimentation, shepherding or husbandry has been linked to this, but blood affinity, tribal affiliation, and family interdependence have not been violated. It is not the tribes-economy-zones that are separated but the property-economic groups and social strata in the middle of the same tribe" 53 . Thus, V. Petrov considers that wealthy members of society and all the owners of cattle roamed, and those of the members of the family who did not have enough livestock, the poor did not roam and engaged in farming. Thus, in his opinion, the opposite is formed between pastoralists and farmers, which was caused not by the geographical conditions of the landscape zones, but by the property difference between the two economic groups in common in clan or breeding affiliation. In the same way, the researcher also solved the "economic settlement problem"; in winter the Scythians were together (nomads and farmers) in one place adapted for a sustainable life with herds, and in the spring the wealthy cattle ranch rolled from place to winter, moving cattle from place to place, in autumn again the nomads drove the herds to wintering, "where the indescribable poor poverty remained" ".54 Such views of V. Petrov in no way contradict the conclusions of modern researchers of the history of nomadic peoples of Eurasia and, in particular, the Black Sea Nogayans ${ }^{55}$, and therefore retain their scientific value.

\footnotetext{
52 Петров В. Етногенез слов'ян. Ст. 165-169.

${ }^{53}$ Ibid. Ст. 166-167.

${ }^{54}$ Ibid. Ст. 168-169.

55 Грибовський В.В. Ногайські орди Північного Причорномор'я у XVIII - на початку XIX ст.: Дис. на здобуття наук. ступеня канд. іст. наук. Запоріжжя, 2006. Ст. 143-166.
} 
The significant expansion of the archaeological source base over the last decades confirmed V. Petrov's thesis about two socio-economic massifs within Scythia. However, in modern Scythology, the fact of zonalgeographical and at the same time ethnic, division of Scythia is widely accepted. Archaeology data testify to the traditional economic orientation of the steppe to nomadic farming, and to the forest-steppe to agriculture and grain production for sale. Instead, V. Petrov's thesis on the ethnic homogeneity of Scythia is unlikely to be agreed by most researchers today. The population of the forest-steppe Scythia was probably local and has continued its development since the previous era. Regarding the steppe Scythia, then here nomadic or royal Scythians predominately Iranianspeaking were the absolute masters in VII - III centuries $\mathrm{BC}^{56}$.

In opinion of modern Scythologists, the population of Scythia was ethnically diverse, and the Scythian ethnic group had heterogeneous character, in other words, formed on the basis of both a local component (the culture of the historic Cimmerians, formed on the basis of a convenient culture of the Late Bronze Age) and of the arrived ProtoScythian tribes. The process of formation of the Scythian ethnic group took place within the framework of a single ethno-social organism, formed as a result of the conquest of the Proto-Scythians / early Scythians of the Cimmerian tribes. The stability of this ethno-social structure, essentially, was ensured by the presence of a military-political organization, which was an instrument of domination of the ruling top of the Scythian society, which relied on "natural" subjects, over tributary groups of the nomadic population $^{57}$.

\section{CONCLUSIONS}

Although V. Petrov's unique approach to the issue of Scythian ethnos did not find support in a scientific community (except for M. Braichevskyi ${ }^{58}$ ), but was not refuted by someone (although some of the Iranians and Scythologists felt a certain hostility to the views of the researcher ${ }^{59}$ ). As a result, to a certain extent, this issue remains open in Scythology ${ }^{60}$.

V. Petrov's thesis of the existence of the Great Scythian Empire (Horse Riding) extended from the Alps to the Altai failed to stand the test

${ }^{56}$ Толочко П.П. Слово про В.П. Петрова - видатного українського археолога. Ст. 8.

${ }^{57}$ Мурзин В.Ю. Происхождение скифов: основные этапы формирования скифского этноса. Ст. 79.

${ }_{58}^{58}$ Брайчевський М.Ю. «Русские» названия поргов у Константина Багрянородого. Ст. 19-30.

59 Грантовский Э.А., Раевский Д.С. Об ираноязычном и «индоарийском» населении Северного Причерноморья в Античную эпоху. Этногенез народов Балкан и Северного Причерноморья. М.: Наука, 1984. Ст. 52.

${ }^{60}$ Кравченко Н., Павленко Ю. Коментар до праці «Походження українського народу». Петров В. Походження українського народу. К.: МП «Фенікс», 1992. Ст. 129. 
of time. At most, the Great Scythia, as a political union, since its rise in $\mathrm{V}$ century to the first half of IV century BC covered the borders of presentday steppe and forest-steppe Ukraine, Moldova and Dobruja. At the same time, the nomadic peoples of the Scythian cultural appearance actually occupied vast, mostly steppe areas of Eurasia, from the Danube to Mongolia and northern China.

In addition, according to modern Scythology, the development of Scythian statehood had a discrete character, because not only internal but also external objects of exploitation were required for the stable development of strong nomadic formations. The latter played a significant role in the nomads as a result of the limited economic opportunities of extensive livestock farming, as well as the military superiority of the settled peoples. Throughout their history, the Scythians have not neglected such sources of income as theft and the collection of tribute from the tributary population, as well as other similar means of obtaining the products of crafts and agriculture ${ }^{61}$. Modern researchers believe that the object of exploitation of the Scythian nomads was the population of the Transcaucasia and Western Asia (at the time of the "Kingdom of Ashkuz" in VII century to the first half of the VI century BC) and agricultural tribes of the Ukrainian forest steppe at the time of the existence of the Northern Black Sea Scythia (IV century BC). In addition, the consolidation of the nomadic population of Scythia was influenced by the confrontation between the nomads and the forest-steppe farmers.

In general, today Scythologists speak about the discreteness of the development of the culture of European Scythians, which is reflected in archaeological, political, economic, and geographical data. The gap in the history of European Scythia falls in the second half of VI century BC. Archaeological materials demonstrate the absence of a gradual transition from archaic pre-classical culture. Among the most probable reasons, the researchers call the forthcoming of a new population group that brought with it new traditions in all spheres of life, which led to the termination of Old Scythia's culture, or at least to its major transformation.

In general, we can say that although not all ideas, including in the field of Scythian studies, expressed by V. Petrov were "heard" by contemporaries or withstood the test of time. However, his works are distinguished by the breadth of their approach to ethnic issues, and they are not based on a thorough scientific analysis, not from the point of national prejudice. Thus, today and in the future the researcher of the ancient

${ }^{61}$ Хазанов А.М. Социальная история скифов. М.: Наука, 1975. 255 ст.; Тереножкін О.І. Класи і класові відносини у Скіфії. Археологія. 1975. Вип. 15. Ст. 10-11; Мурзин В.Ю. Происхождение скифов. Ст. 79. 
history of Ukraine, and in particular the history of the Scythians, can not do without the scientific works of a prominent Ukrainian scientist.

V. Petrov had a passion for nontrivial scientific hypotheses, which he put forward and developed in his various scientific studios. This trait could not affect the attitude of the scientific community to his work. Often it was very critical, and sometimes it was expressed in the direct rejection or ignoring of his ideas. However, today, from a certain point of view, it becomes clear what an important thing a person who constantly paid research attention to non-traditional concepts and approaches to solving scientific issues becomes aware of, because this is so often lacking in everyday scientific life.

\section{SUMMARY}

125 years since the birth and 50 years since the death of Viktor Platonovych Petrov marks in the year 2019. This Ukrainian intellectual, with extraordinary erudition and breadth of scientific interests and views, can certainly be called the outstanding figure of humanitarian thought of the XX century; he is historian, archaeologist, philologist, philosopher and talented writer among neoclassics (literary double Domontovych and Ber). However, he remains little known not only in the world scientific space, but also in its homeland. V. Petrov's multifaceted scientific heritage is covered by oblivion. The "Scythian component" of the scientist's work is not an exception, which is still out of the sight of most modern researchers. In this article the author analyses V. Petrov's views on various issues of the history of the Scythians.

\section{REFERENCES}

1. Абаев В.И. Осетинский язык и фольклор. М.; Л., 1949. Т. І. 607 ст.

2. Абаев В.И. Выступление на круглом столе “Дискусионные проблемы отечественной скифологии”. Народы Азии и Африки. 1980. № 5. Ст. 129-130.

3. Абаев В.И. Геродотовские Skythai Geōrgoi. Избранные труды. Религия, фольклор, литература. Владикавказ, 1990. Ст. 98-101.

4. Автобіографія Віктора Платоновича Петрова / Вступне слово та примітки В. Корпусової. Слово і час. 2002. № 10. Ст. 51-52.

5. Алексеев Т.И. Этногенез восточных славян по данным антропологии. М.: Наука, 1973. 332 ст.

6. Алексеев А.Ю. Хронография Европейской Скифии VII-IV веков до н. э. Санкт-Петербург: Издательство Государственного Эрмитажа, 2003. 416 ст. 
7. Андрєєв В. Віктор Петров: Нариси інтелектуальної біографії вченого. Дніпропетровськ: Герда, 2012. 476 ст. (серія "Dniproviana").

8. Андрєєв В. Скіфська генеалогічна легенда в інтерпретаціях Віктора Петрова. Південний архів. Історичні науки. Херсон: Вид-во ХДУ, 2009. Вип. 31/32. Ст. 15-29.

9. Андрєєв В. Віктор Петров: “скіфський сюжет” інтелектуальної біографії. Український історичний журнал. 2010. № 2. Ст. 190-202.

10. Андрєєв В. Віктор Петров: вирішення проблеми скіфської мови у науковому спадку вченого. Гуманітарний журнал. Дніпропетровськ, 2010. Вип. 3/4 (літо-осінь). Ст. 30-38.

11. Андрєєв В. Скіфська державність у працях В. Петрова: політичний та етнічний аспекти. Література та культура Полісся. Ніжин: Вид-во НДУ ім. М. Гоголя, 2011. Вип. 63. Ст. 92-98.

12. Андрєєв В. Антична доба в історії України в контексті “теорії епох" В. Петрова. Наукові праці. Історія. Миколаїв: Вид-во ЧДУ ім. Петра Могили, 2012. Вип. 195 (Т. 207). Ст. 70-74.

13. Артамонов М.И. О землевладении и земледельческом празднике у скифов. Ученые записки ЛГУ. Серия историчеких наук. № 95. Вып. 15. Л., 1948. Ст. 3-20.

14. Артамонов М.И. К вопросу о происхождении скифов. Вестник древней истории. 1950. № 2. Ст. 37-47.

15. Артамонов М.И. Киммерийцы и скифы (от появления на исторической арене до конца IV в. до н. э.). Л.: Изд-во ЛГУ, 1974. 156 ст.

16. Березовський I. Визначний дослідник. Народна творчість та етнографія. 1970. № 6. Ст. 57-62.

17. Білокінь С. Довкола таємниці. Петров В. Походження українського народу. К.: МП “Фенікс”, 1992. Ст. 165-192.

18. Болтенко М.Ф. Herodoteanea. Maтериаль по археологии Северного Причерноморья. Вып. 3. Одесса, 1959. Ст. 38-55.

19. Брайчевський М.Ю. "Русские" названия порогов у Константина Багрянородого. Земли Южной Руси в IX-XIV вв. К., 1985. Ст. 19-30.

20. Брайчевський М.Ю. В.П. Петров - учений-універсал. Археологія. 1990. № 3. Ст. 95-100.

21. Варнеке Б.В. Легенди про походження скіфів. Записки Історико-філологічного відділу ВУАН. 1928. № 76. Ст. 43-68.

22. Віктор Платонович Петров. Украӥнський історичний журнал. 1969. № 9. Ст. 158.

23. Граков Б. Скіфи. К.: Видавництво АН УРСР, 1947. 93 ст. 
24. Граков Б.Н., Мелюкова А.И. Об этнических и культурных различиях в степных и лесостепных областях европейской части СССР в скифское время. Вопросы скифо-сарматской археологии. М.: Издательство АН СССР, 1954. Ст. 39-93.

25. Граков Б.Н. Скифский Геракл. Краткие сообщения Института истории материальной культуры. Вып. XXXIV. М. -Л., 1950. Ст. 8-9.

26. Граков Б.Н. Скифы. М.: Изд-во Москов. ун-та, 1971. 202 ст.

27. Грантовский Э.А., Раевский Д.С. Об ираноязычном и “индоарийском" населении Северного Причерноморья в Античную эпоху. Этногенез народов Балкан и Северного Причерноморья. М.: Наука, 1984. Ст. 50-54.

28. Грибовський В.В. Ногайські орди Північного Причорномор'я у XVIII - на початку XIX ст.: Дис. на здобуття наук. ступеня канд. іст. наук. Запоріжжя, 2006. 200 ст.

29. Зализняк А.А. Проблемы словяно-иранских языковых отношений в древнейший период. Bопросы славянского языкознания. 1962. Вып. 6. Ст. 28-45.

30. Зализняк А.А. Контакты между славянами и скифосарматскими племенами. Краткие сообщения Института славяноведения. 1963. Вып. 28. Ст. 3-22.

31. Ильинская B.A. Скифы Днепровского лесостепного Левобережья. К.: Наукова думка, 1963. 267 ст.

32. Ильинская В.А. Скифия VII-IV до н. е. К.: Наукова думка, 1983.378 ст.

33. Клейн Л. С. Территория и способ погребения кочевых скифских племен по Геродоту и археологическим данным. Археологический сборник Государственнго Эрмитажа. Вып. 2. Л.., 1961. Ст. 45-56.

34. Клейн Л.С. Легенда Геродота об азиатском происхождении скифов и нартский эпос. Вестник древней истории. 1975. № 4. Ст. 14-27.

35. Клейн Л.С. Проблема “Х”. Проблемь скифо-сибирского культурно-исторического единства. Кемерово, 1979. Ст. 18-22.

36. Клейн Л.С. Откуда арии пришли в Индию. Вестник Ленинградского университета. 1980. Вып. 4 (20). Ст. 35-40.

37. Клейн Л.С. Происхождение скифов царских по археологическим данным. Советская Археология. 1963. № 4. Ст. 27-35.

38. Клейн Л.С. Третья гипотеза о происхождении скифов (Выступление на круглом столе “Дискусионные проблемы 
отечественной скифологии"). Народы Азии и Африки. 1980. № 6. Ст. 72-74.

39. Клейн Л.С. Индоарии и скифский мир: общие истоки идеологии. Народы Азии и Африки. 1987. № 5. Ст. 63-82.

40. Корпусова В.М. В. Петров (Домонтович): етногенетика як свобода самовиявлення. Слово і час. 2002. № 10. Ст. 17-25.

41. Кравченко Н., Павленко Ю. Коментар до праці "Походження українського народу”. Петров В. Походження украӥнського народу. К.: МП “Фенікс", 1992. Ст. 114-164.

42. Кривцова-Гракова О. А. Степное Поволжье и Причерноморье в эпоху поздней бронзы. Материаль и исследования по археологии СССР. 1955. № 46. 166 ст.

43. Кухаренко Ю.В. К вопросу о славяно-скифских и славяносарматских отношениях. Советская археология. 1954. Т. 19. Ст. 111-120.

44. Лелеков Л.А. R. Girshman. L'Iran et la migration des IndoAryens et des Iranians. Народы Азии и Африки. 1978. № 5. Ст. 220-226.

45. Лелеков Л.А. Выступление на круглом столе “Дискусионные проблемы отечественной скифологии”. Народы Азии и Африки. 1980. № 5. Ст. 125-128.

46. Лелеков Л.А. Проблемы индоиранских аналогий к явлениям скифской культуры. Скифо-сибирское культурно-историческое единство. Кемерово, 1980. Ст. 118-125.

47. Лелеков Л.А. Выступление на круглом столе "Индоарии и скифский мир: общие истоки идеологии". Народы Азии и Африки. 1987. № 5. Ст. 86-88.

48. Миллер В. Осетинские этюды. Ч. 1-3. М., 1881-1887.

49. Мурзин В.Ю. Происхождение скифов: основные этапы формирования скифского этноса. К.: “Наукова думка”, 1990. 88 ст.

50. Петраускас О.В. Балто-слов'янські відносини за роботами Віктора Платоновича Петрова. Проблеми походження та історичного розвитку слов'ян. Збірник наукових статей присвячений 100-річчю з дня народження Віктора Платоновича Петрова. Київ-Львів: "РАС”, 1997. Ст. 20-25.

51.Петров В.П. Пантелеймон Куліш у 50-ті роки. Життя, ідеологія, творчість. Монографія. Збірник Історико-Філологічного Відділу Української Академії Наук. № 88. Київ, 1929. 572 ст.

52. Петров В.П. Из этнонимики и топонимики Северного Причерноморья. Материаль по археологии Северного Причерноморья. Одесса, 1962. Вып. 4. Ст. 230-238. 
53. Петров В.П., Макаревич М.Л. Скифская генеалогическая легенда. Советская археология. 1963. № 1. Ст. 20-31.

54. Петров В. Давні слов'яни та їх походження (До проблеми слов'янського етногенезу). Український історичний журнал. 1963. № 4. Ст. 36-44.

55. Петров В.П. Язык. Этнос. Фольклор. Автореферат по совокупности работ на соискание ученой степени кандидата филологических наук. К., 1966. 62 с.

56. Петров В. Скіфи. Мова і етнос. К., 1968. 149 ст.

57. Петров В. Етногенез слов'ян. Джерела, стан розвитку i проблематика. К., 1972. 214 ст.

58. Петров В. Походження українського народу. К. МП: “Фенікс”, 1992. 192 ст.

59. Седов В.В. Происхождение и ранняя история славян. М.: Наука, 1977. 156 ст.

60. Семенов-Зуссер С.А. Скіфи-кочовники на території Північного Причорномор'я. Наукові записки Харківського Державного педагогічного інституту. Т. І. Харків, 1939. Ст. 168-173.

61. Тереножкин А.И. Киммерийцы. К.: Наукова думка, 1976. 220 ст.

62. Тереножкін О.І. Класи і класові відносини у Скіфії. Археологія. 1975. Вип. 15. Ст. 3-13.

63. Толочко П.П. Віктор Петров - дослідник українського етногенезу. Петров В. Походження украӥнського народу. К.: МП "Фенікс", 1992. С. 3-8.

64. Толочко П.П. Слово про $\quad$ В.П. Петрова - видатного українського археолога. Проблеми походження та історичного розвитку слов'ян. Збірник наукових статей присвячений 100-річчю з дня народження Віктора Платоновича Петрова. Київ-Львів: "РАС", 1997. Ст. 5-8.

65. Трубачов О.Н. О синдах и их языке. Bопросы языкознания. 1976. № 4. Ст. 39-63.

66. Трубачов О.Н. Лингвистическая переферия древнейшего славянства. Индоарийцы в Северном Причерноморье. Bonpocbl языкознания. 1977. № 6. Ст. 13-28.

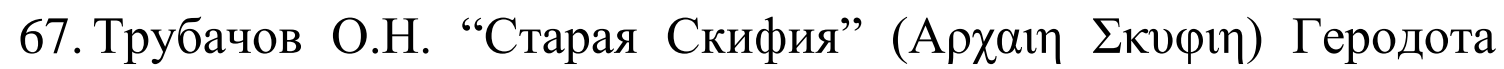
(IV. 99) и славяне. Лингвистический аспект. Bопросы языкознания. 1979. 4. Ст. 29-45.

68. Трубачов О.Н. Выступление на круглом столе “Дискусионные проблемы отечественной скифологии”. Народь Азии и Африки. 1980. № 5. Ст. 117-118. 
69. Трубачов О.Н. Indoarica в Северном Причерноморье: Источники. Интерпретация. Реконструкция. Вопросы языкознания. 1981. № 2. Ст. 3-21.

70. Трубачов О.Н. Indoarica в Скифии и Дакии. Этногенез народов Балкан и Северного Причерноморья. М., 1984. Ст. 148-152.

71. Трубачов О.Н. Этногенез и культура древнейших славян. Лингвистические исследования. М.: Наука, 2003. 489 ст.

72. Франко 3. Людина покликання та обов'язку. Літературна Україна. 1984. 1 листопада. № 44 (4089). С. 5.

73. Франко 3. Він не встиг написати мемуарів. Київ. 1984. № 12. C. 84-87.

74. Хазанов А.М. Социальная история скифов. М.: Наука, 1975. 255 ст.

75. Штительман Ф.М. Поселения античного периода на побережье Бугского лимана. Материаль и исследования по археологии СССР. № 50. 1956. Ст. 255-272.

76. Юсова Н. Становлення радянської етногенетики (в світлі глотогонічної теорії М. Марра). Проблеми історії Украӥни: факти, судження, пошуки. Міжвідомчий збірник наукових праць. Вип. 15. К.: Інститут історії НАН України, 2007. Ст. 168-189.

77. Яценко И.В. Скифия VII-V вв. до н. э. М.: Наука, 1959. 214 ст.

78. Яценко И.В., Раевский Д.С. Некоторые аспекты состояния проблемы (обзорная статья). Круглый стол “Дискусионные проблемы отечественной скифологии". Народь Азии и Африки. 1980. № 5. Ст. 102-117.

79. Andryeyev V., Karjaka O. Problems of the Baltic-Slavic Linguistic unity and Ancient Prussian language in the scientific heritage of Victor Petrov. Східноєвропейський історичний вісник. Вип. 10. 2019. Ст. 8-17.

80. Müllenhoff K. Uber die Herkunft und Sprache der pontischen Skithen und Sarmaten. Monatsberichte der K. Preussischen Akademie der Wissenschaften. 1866. S. 549-576.

81. Tallgren A. M. La Pondide Prescythique après l'introduction des metaux. Eurasia Septentrionalis Antiqua. Helsinki, 1926. Vol. II. P. 201-223.

\section{Information about the author: Andryeyev V. M.,}

PhD hab. (History), Professor,

Professor at the Department of Ukraine's History, Borys Grinchenko Kyiv University 18/2, Bulvarno-Kudriavska str., Kyiv, 04053, Ukraine 


\section{THE METHODOLOGY OF THE RESEARCH OF EPISTEMOLOGICAL FOUNDATIONS OF UKRAINIAN HISTORICAL AND PEDAGOGICAL NARATIVE (MID-NINETEENTH - LATE TWENTIETH CENTURY)}

\section{Haliv M. D.}

\section{INTRODUCTION}

In the course of the study of the epistemological foundations of the Ukrainian historical and pedagogical narrative of the mid-nineteenth - late twentieth centuries one must rely on the principles of methodological pluralism and, to some extent, methodological relativism. Methodological pluralism implies multiplicity, multivariance, the alternative use of methodological approaches to solving of the set tasks. Methodological relativism obliges to take into account constant variability, relativity, precariousness, arbitrariness of methodological approaches and the tools of cognition, its dependence on socio-cultural circumstances.

\section{Presenting the main material}

Characterizing the theoretical and methodological principles of the study, we distinguish three levels of methodology: general scientific, specific scientific and instrumental (applied).

The general scientific level of the research is to combine the foundations of the epistemological foundations of analytical and narrative philosophy of history and the defining theoretical and methodological approaches to the solution of scientific problems: axiological, synergetic, paradigmatic, hermeneutical, socio-cultural, civilizational and phenomenological.

The combination of the discourses of analytical and narrative philosophy of history, which are considered pole by their ontological and epistemological positions, may seem unjustified or at least eclectic. Notwithstanding the complex theoretical constructs of these paradigms, we consider it necessary to base our study on the views of those neo-positivists who declare epistemological optimism, rejecting extreme skepticism bordering on agnosticism. The representatives of the analytical philosophy of history, despite the influence of the postmodern tradition, express confidence in the historian's ability to grasp the past at least fragmentarily, reconstruct its event-factual components. In particular, A. Danto wrote in 
1965: historians sometimes manage to come to the true statements about what is past for them ${ }^{1}$. Thus, seeking the epistemological foundations of the Ukrainian historical and pedagogical narrative of the period, we express our confidence in the possibility of an adequate reflection of epistemic foundations in the works of historians of pedagogy.

At the same time, we accept the concepts of narrative philosophy of history, that narrative is inherent in all, without exception, historical and pedagogical works. However, we are strongly opposed to the radical direction of the narrative philosophy of history. As it is well known, the representatives of the latter claim that historical reality is reduced to the framework of a text outside of which, it wasn't, isn't and will not be. Radical narratives deny the objectivity of the knowledge about the past, the historian's ability to reproduce even small details of historical reality, and therefore reject the historical methodology. To adopt such a position would be to acknowledge the unscientific nature of any research that is equivalent to self-denial for a scientist. Instead, we share moderate narrativeconstructive ideas about the existence of opportunities for the historian through the scientific critique of historical sources to learn about historical reality. The proponents of moderate narrative discourse favor interpretation, calling it "construction" or "constructed realism". V. Lectorskyi, in particular, emphasized that any construction involves the presence of a multi-layer and multi-level reality in which it is realized and which it detects and tries to transform. Therefore, the constructiveness of anything is not the evidence of its unrealistic nature ${ }^{2}$. In this view, we interpret our research as a large-scale interpretation based on the "basic data", designed to reconstruct (at the same time and construct) the cognitive, ideological, conscious reality - the knowledge bases of the Ukrainian historical and pedagogical narrative.

The axiological approach is based on the principles of axiology - the doctrine of values, the philosophical theory of values, which clarifies the qualities and properties of objects, phenomena, processes that can satisfy the needs, interests and desires of people ${ }^{3}$. As A. Udod noted, the axiological approach in the scientific study of past human society focuses on the question of the scientist's attitude to the subject of the research. This attitude reflects the value approach to the object and is expressed in valuation judgments ${ }^{4}$. The results of the study depend directly on the

\footnotetext{
${ }^{1}$ Данто А. Аналитеческая философия истории. Москва: Идея-пресс, 2002. С. 34.

2 Лекторский В.А. Реализм, антиреализм, конструктивизм и конструктивный реализм в современной эпистемологии и науке. Конструктивистский подход в эпистемологии и науках о человеке: сб. науч. ст. Москва : Канон+РООИ «Реабилитация», 2009. С. 37.

${ }_{3}^{3}$ Філософський енциклопедичний словник. Київ: Абрис, 2002. С. 14.

${ }^{4}$ Удод О. А. Аксіологічний (ціннісний) підхід у методології та методиці історії. Наукові праці історичного факультету Запорізького державного університету. 2000. Вип. XI. С. 165.
} 
evaluation activity of a historian. The application of an axiological approach allows us to put interpretative and evaluative judgments in our study on a solid foundation of universal (Christian), national, civic, and personal values. In this context, it is appropriate to cite the opinion of the Polish researcher of historical methodology E. Domanska, who noted that at the present stage of the development of science, the reflections on history have more to do with ethics than with epistemology ${ }^{5}$. Considering the axiological approach, the intellectual production of domestic researchers of the history of pedagogy, regardless of its ideological direction, scientific novelty and logic-justifying representativeness, is evaluated only positively and interpreted as universal and at the same time creative. In addition, it is the axiological approach that makes it possible to separate the evaluative judgments of Ukrainian historians of pedagogy from the narrative and factual layer of their narrative, to see their moral, national, political, and personal values.

The chosen axiological position also makes us use the principles of the "national-existential methodology" developed by Drohobych scientists V. Ivanyshyn and P. Ivanyshyn. On this basis, the obligation arises for a researcher, who interprets historical sources and events, to regard the nation as an axial reality that determines both the existence of the individual and his hermeneutical capacity ${ }^{6}$. Recognizing our Ukrainian identity, we will not dissociate ourselves from Ukrainian-centric interpretations, and therefore the interpretation of the fundamental epistoms of the national historical and pedagogical narrative will be carried out on the basis of national values, which we consider to be quite natural phenomenon, justified both from the point of view of cognitive and social science.

The synergistic approach is to be understood as historical and pedagogical phenomenon, a self-organizing system, joined by linear and nonlinear connections, polyphonic, alternative and variational processes, undisclosed and underdeveloped states ${ }^{7}$. The use of the synergistic approach provides the consideration of Ukrainian historical and pedagogical science as a self-organized system, the components of which are manifested in institutional, personal, functional, historiographicalnarrative dimensions. At the same time, each individual work and the set of works of a particular historian of pedagogy can be interpreted as a complex

\footnotetext{
${ }^{5}$ Domańska E. Mikrohistorie. Spotkania w międzyświatach. Poznań : Wydawnictwo Poznańskie, 1999. S. 50.

${ }^{6}$ Іванишин П. Національно-екзистенціальна інтерпретація (основні теоретичні та прагматичні аспекти). Монографія. Дрогобич : «Відродження», 2005. С. 17. C. 37 .

${ }^{7}$ Богуславський М. Структура сучасного історико-педагогічного знання. Шлях освіти. 1999. № 1.
} 
organized intellectual system, saturated with logical and grammatical, persuasive, theoretical and ideological layers, coordinates of time and space (E. Topolskyi), theoretically loaded processes, facts, hidden and expressive cognitive procedures, values and emotional substrates, "narrative logic" (F. Ankersmith).

The paradigmatic approach is based on the theory of scientific revolutions by T. Kuhn, who actually proposed the concept of "a paradigm". Under paradigms, he understood recognized by all scientific achievements, which give the scientific community a model of problemsolving and their solutions over a period of time ${ }^{8}$. According to O. Ruptash, paradigms set the boundaries of the problematic field of a scientific discipline, possible ways of seeking the answers and solution of problems, acceptable stereotypes of the interpretation of scientific discoveries. Despite the understanding of the development of science through the prism of "paradigms" and "scientific communities" only in the field of natural sciences, the humanities have taken a pragmatic approach as well. The concept of paradigm in humanities, according to O. Ruptash, is becoming more meaningful - it is a worldview basis of knowledge and comprehension of the world, which accumulate life experience, value and meaning, beliefs and characteristic of a particular culture, history, social group; the way of thinking'.

The hermeneutical approach is based on hermeneutics - the theory of interpretation of texts, and therefore leads to the use of different mechanisms of interpretation of sources: individual-psychological, social, pedagogical, moral, etc. One of the leading specialists in the philosophical hermeneutics of science G.-G. Gadamer in his work "The truth in the Humanities" (1953) suggested the way to reach the truth through the prism of interpretation and understanding of source information. For this purpose, in his opinion, it is necessary for a researcher to listen to the interpretation and to be in interpretation ${ }^{10}$. The philosopher meant a special type of psychological penetration into the text, through which one understands certain meanings. The relevance of the hermeneutical approach in our study is dictated by the need for a certain empathic understanding of the sources of epistemological constructs used in the texts.

The sociocultural approach is based on understanding of the past, including the intellectual production of scientists - historians of pedagogy, through the lens of sociocultural identities (primarily civilizational, national, religious, social). The sociocultural approach relies on cultural

\footnotetext{
${ }^{8}$ Кун Т. Структура научных революций. Москва : Прогресс, 1977. С. 11. C. $23-24$.

9 Рупташ О. В. Парадигмальний підхід у гуманітарних науках. Нова парадигма. 2014. Вип. 122.

${ }^{10}$ Гадамер Г.-Г. Істина і метод. В 2 т. Київ : Юніверс, 2000. Т. 2. С. 41.
} 
concepts, in particular on understanding the phenomenon of culture. The latter, according to E. Kovalenko acts in three aspects: 1) culture as a program of activity and behavior, as a driving factor of action; 2) culture as a continuity, since culture is the experience of human activity, which is passed on from generation to generation (and culture is not only transmitted on the basis of succession, it is developing, enriching); 3 ) culture as accumulation of social and pedagogical experience. This aspect combines the two previous: socially approved and meaningful experience, which is a program of behavior, is not only transmitted on the basis of succession, but also accumulates, which then allows to present it as a socio-pedagogical historical phenomenon that appears as an object of knowledge ${ }^{11}$. It is important in the context of a sociocultural approach is the concept of "signifying practices" (from the Latin significatum meaningful). This concept refers to the ways and mechanisms by which identity is self-represented and recognized by others ${ }^{12}$. Revealing in the narratives of Ukrainian historians of the pedagogy "signifying practices" makes it possible to get closer to the understanding of their socio-cultural identity models.

It is close to the socio-cultural is the civilizational approach, which, according to G. Kornetov, makes it possible to comprehend the development of the historical-pedagogical process, taking fully into account the material-economic, socio-political and spiritual-moral foundations in history. The object of attention of the civilization approach is the totality of all forms of life of a society - material, ideological, cultural, religious, moral, etc. - in unity and gravity. Moreover, the anthropocentricity and cultural correspondence of the civilizational approach give such a view to the historical and pedagogical process, through which the problem of the essential forces of a man in the concrete and historical multifaceted forms of social being arises and solves ${ }^{13}$. In the study of the historical and pedagogical narrative of domestic scientists the civilizational approach serves as means of knowledge of civilizational visions and identities of authors.

The phenomenological approach, according to E. Kovalenko's definition, means that the elements of pedagogical knowledge are analyzed not simply as a historical constanta, but as the derived from the subjective world of a pedagogue, as a product of individual and social consciousness

${ }^{11}$ Коваленко Є.І. Методологічна функція історії педагогіки у становленні майбутнього педагога. Наукові записки Ніжинського державного університету ім. Миколи Гоголя. Серія : Психологопедагогічні науки. 2012. № 4. С. 29-30.

12 Нагорна Л.П. Соціокультурна ідентичність: пастки ціннісних розмежувань. Київ : ІПіЕНД ім. І. Ф. Кураса НАН України, 2011. С. 57.

${ }^{13}$ Корнетов Г. Б. Теория истории педагогики : монография. Москва : АСОУ, 2013. С. 178-179. 
and experience, and its different sides are revealed as indices of subjective understanding (subjectivity in dyads: knowledge - the personality of a scientist; knowledge - the scientific tradition; knowledge - the scientific community), the individual-historical trajectories of his formation are determined and developed ${ }^{14}$. In revealing the epistemological foundations of the Ukrainian historical and pedagogical narrative, the phenomenological approach is manifested in the explication of the subjective, spiritual, personal, and biographical factor. It directs to the discovery of the "inner world" of historians of pedagogy, their outlook, interests, life senses.

The specific scientific level of the methodology of the research is represented by narrative, imaginary, biographical and prosopographic, synchronous-diachronic, lymological (regional), systematic and complex approaches, as well as combining the principles of historicism, scientificity, objectivity and multifactoriality, priority of documentary factors.

The narrative approach firmly integrated in the methodology of Ukrainian historical and pedagogical science. O. Sukhomlynska noted the absolute narrative for all published scientific works of historical nature ${ }^{15}$. The use of the narrative approach is justified by the understanding that scientific knowledge is represented primarily by narrative - the textual form of presenting the research, its results. Of course, there is also a nonnarrative form of scientific knowledge - the intellectual-thinking rationalempirical activity of a scientist, which is much broader, more extensive and more thorough than its narrative embodiment. However, it is narrative that is a platform for the provision of scientific knowledge for the "republic of scientists". The use of a narrative approach makes it possible to view the heritage of national pedagogical historians as a "meta-narrative" - a large text that has cultural, intellectual traditions and is an imaginary entity characterized by gravity.

The imagiological approach is a concrete scientific manifestation of general scientific socio-cultural and civilizational approaches and relies on imagiology as a theory of interpretation of the images of "other" / "alien". According to I. Kutsym, an essential feature of any culture is the differentiation of its inner ("one's own") from the outer ("alien") space. By distinguishing the inner from the outer, an individual determines his / her belonging to a particular culture. In the process of cultural self-

\footnotetext{
${ }^{14}$ Коваленко Є.I. Методологічна функція історії педагогіки у становленні майбутнього педагога. Наукові записки Ніжинського державного університету ім. Миколи Гоголя. Серія: Психологопедагогічні науки. 2012. № 4. С. 30.

${ }^{15}$ Сухомлинська О. Історико-педагогічне дослідження та його «околиці». Шлях освіти. 2005. № 4. C. 45 .
} 
identification, the symbolic notion of the boundary of cultural space plays a key role. The inner space is designated as "our", "native", "safe", "cultural", etc. as opposed to "other", "alien", "hostile", "dangerous", which clearly distinguishes from "one's own". Scientists refer the image of "other" / "alien" as the most ancient archetypal ideas, and the binary opposition "native" / "alien" to the basic universals of human consciousness ${ }^{16}$. The imagiological approach makes it possible to identify the tactics of "otherness" used in the Ukrainian historical and pedagogical narrative of the time outlined.

The biographical approach is a comprehensive study of a personal life path (in this case, a national historian of pedagogy) against the background of the era. According to G. Belan, the scientific biography and creative work of a person is not only the interpretation of his scientific reflections, but also the evidence of worldviews, life concepts, which are the unique reflection of the social processes of the historical era ${ }^{17}$. O. Sukhomlynska actively uses the notion "pedagogical persona", which means something more than a scientific, educational or creative biography, rather a personalized process of formation of values, culture within the humanitarian tradition, and its specific model ${ }^{18}$. This understanding approaches such areas of historical research as historical prosopography and intellectual biography. Therefore, in the context of biographical and prosopographic approaches, the views of historians of pedagogy on the past are explored.

The synchronic-diachronic approach ensures the optimum of the temporal composition of our narrative. According to E. Topolskyi, all types of historical works can be placed on an axis that stretches between the composition that reflects the passage of time from the past to the future, and one that refers to a specific time-lapse, but does not show a chronological sequence of events. And the real narrations are the mixture of diachrony and synchrony ${ }^{19}$. Paying attention to the considerable time span (approximately one and a half century) that encompasses our study, the presentation of the material is built more on a diachronic type of composition, at the same time synchrony was manifested in comparing the ideas of Ukrainian historians of pedagogy of the Overdnipro and Western Ukrainian lands, as well as of the Ukrainian diaspora.

\footnotetext{
${ }^{16}$ Куций I. Цивілізаційні ідентичності в українській історіографії кінця XVIII - початку XX ст. : між Слов’янщиною та Європою. Тернопіль : Підручники і посібники, 2016. С. 33-34.

17 Бєлан Г. В. Біографічний метод в історико-педагогічній науці: провідні тенденції становлення. Педагогічний дискурс. Хмельницький, 2013. Вип. 15. С. 50.

${ }^{18}$ Сухомлинська О.В. Історико-педагогічний процес : нові підходи до загальних проблем. Київ : А.П.Н., 2003. С. 42.

19 Топольський С. Як ми пишемо і розуміємо історію : Таємниці історичної нарації. Київ : К.І.С., 2012. C. 126.
} 
The lemological (regional) approach is dictated by the need to take into account the political affiliation of different regions of Ukraine to foreign countries (Russian and Austro-Hungarian empires, Poland, Czechoslovakia, Romania, the USSR) in the studied era. Of course, a political factor is important, but not decisive, in shaping the content of the regional approach. According to Y. Vermenych, who develops the theory of historical regionalism, it is necessary to change the traditional sociopolitical component of this trend into a socio-cultural one ${ }^{20}$. According to O. Sukhomlynska, the regional approach is based on the understanding of the region as a social and geographical space, where human socialization, formation, preservation and translation of life forms take place ${ }^{21}$. Taking into account the socio-cultural identities of historians of pedagogy as the representatives of a particular region is necessary to understand the knowledge-based principles of their narrative.

We treat the systemic approach as a concrete and scientific embodiment of synergetics. According to E. Kovalenko, a systematic approach requires to explore any historical and pedagogical phenomenon as a systemic formation, highlighting the features of the system: the presence of aggregate elements, each of which is a minimal unit having a limit of division within this system; the presence of certain links and relationships between the system elements; the functioning of the system and its properties due to its structural specificity; the presence in the system of a certain level of integrity, that is, the internal integrative qualities that result from the interaction of its elements; the presence of a common structure that integrates all elements of the system and ensures the completeness of the named elements and coherence of all their functions; the availability of connections to other systems; the dedication of the system to solving some problem ${ }^{22}$. This approach makes it possible to consider all the "specific texts" and "great texts" of national historians within the framework of the imagined cultural and scientific phenomenon - the Ukrainian historical and pedagogical narrative. At the same time, it is the systematic approach that allows to systematize the epistemological foundations of the narrative, dividing them into worldphilosophical, political-ideological, socio-cultural, scientific-interdisciplinary, methodological-instrumental. Closely related to the systematic approach is the comprehensive approach that examines the

20 Верменич Я. Нова локальна історія та історична регіоналістика: експлікація термінів. Регіональна історія України. Вип. 1. С. 13-19.

${ }^{21}$ Сухомлинська О. Історико-педагогічний процес в Україні: регіональний вимір. Шлях освіти. 2007. № 2. С. 42

22 Коваленко С.I. Методологічна функція історії педагогіки у становленні майбутнього педагога. Наукові записки Ніжинського державного університету ім. Миколи Гоголя. Серія: Психологопедагогічні науки. 2012. № 4. С. 29. 
object and subject of the research, the scientific problem from the standpoint of integrity and the systematic nature itself.

The principle of historicism is to take into account the specific historical conditions of the formation of epistemological foundations of the Ukrainian historical and pedagogical narrative. The principle of scientificity captures the basic features of science and is associated with the way of verifying the truth for the subject in accordance with the canons of rationality: evidence, argumentation, validity, consistency, reproducibility, naturalness, causality, etc. The principle of objectivity requires the reconstruction of the views and ideas of historians of pedagogy impartially, avoiding distortions, exaggerations, and base on the criticism of the sources. The principle of multifactoriality is to involve and take into account the whole complex of information about the events, phenomena, processes and other factors that influenced the development of the epistemological foundations of the Ukrainian historical and pedagogical narrative of the mid-nineteenth and late twentieth centuries.

The applied level of methodological representation is represented by the application of the research methods - general scientific (abstraction, analysis and synthesis, induction, deduction, classification, generalization), interdisciplinary (context-interpretation, cognitive mapping, lexicosemantic and logical-semantic, critical, structural semantic) and special historical (historical-genetic, historical-comparative, historical-typological, historical-systemic, periodization, retrospective).

The contextual-interpretative method allows us to establish the contexts of the formation and reception of the epistemological foundations by Ukrainian historians of pedagogy and, based on the contextualization of the actual interpretation of the information contained in the narratives. The use of the method of cognitive mapping provides a certain reflection of the causal multilevel epistemological program of historical and pedagogical texts by predication (recognition and selection of the optimal hypothesis) and its cognitive modeling in the form of a simplified, schematized "map". Lexical and semantic methods are needed to clarify the semantic aspects of the metaphors and tropes of the language of historians of pedagogy. Critical and structural-systemic methods make it possible to avoid tendencies in the selection and interpretation of historical and pedagogical texts of Ukrainian scholars.

The use of historical-genetic method makes it possible to trace the genesis of the epistemological ideas on which the narratives of national pedagogy were based. Historical-comparative method provides an opportunity to identify common and different views of scientists on different issues of the past development of education and pedagogy on the 
basis of comparing the historical and pedagogical works of different authors at different times. The use of the historical-system method is the key to building the material in proper consistency, coherence and holicity. The historical-typological method should be used to determine the typological affiliation (civilizational, national, religious, etc.) of the basic concepts of the researchers of the historical and pedagogical past. In the analysis of the historiography of the problem, the method of retrospection was applied, which allows to outline the main achievements in the field of the study of the history of historical and pedagogical science.

The categorical thesaurus used in the research is also of methodological significance: epistemological foundations, narratives, Ukrainian historical and pedagogical narratives.

Epistemology is a branch of philosophy that explores historical knowledge evolving scientifically in its all socio-cultural dimensions. At the center of the problematic field of epistemology are the questions concerning the nature of cognition, its genesis, historical evolution, the conditions of reliability of its results, historical change of its structure, socio-cultural status, strategic goals, relationships with the life experience and all diversity of socio-cultural practices ${ }^{23}$. Many scientists outlined epistemology by comparing it with "gnoseology". Some of them believe that gnoseology and epistemology are identical in content, but in German philosophy the theory of knowledge is called "gnoseology", and in French and Anglo-American the expression "epistemology" is common. Therefore, these words can be used as synonyms.

In most western countries, according to V. Petrushenko, epistemology is mainly associated with the study of scientific knowledge only, while gnoseology traditionally studied the processes and forms of cognitive activity at all its levels and in all manifestations ${ }^{24}$. Recognizing the interaction of epistemology and gnoseology (as well as knowledge and cognition), V. Petrushenko himself, of course, separated them, emphasizing the connection of gnoseology with the traditions of classical science, and epistemology with the models of non-classical philosophy ${ }^{25}$. He expanded the subject of epistemology from the study of the scientific to the understanding of any knowledge as a phenomenon. However, a narrow understanding of the subject of epistemology is acceptable to us, since the object of the study is historical and pedagogical knowledge as the product of scientific thinking, that is, scientific knowledge itself.

\footnotetext{
${ }^{23}$ Філософський енциклопедичний словник. Київ : Абрис, 2002. С. 202.

24 Петрушенко В.Л. Епістемологія як філософська теорія знання. Львів : Вид-во ДУ «Львівська політехніка», 2000. С. 3.

${ }^{25}$ Петрушенко В.Л. Епістемологія...С. 27.
} 
Under epistemological principles we mean the defining epistemic constructs that underlie in the foundation of knowledge: ideologicalphilosophic, political-ideological, socio-cultural, scientificinterdisciplinary and disciplinary (historical and pedagogical). The concept of "epistemological foundations" can be compared with the concept of "episteme", proposed by M. Foucault. The philosopher understood by the "episteme" a set of relationships that can unite language practices in a particular era. An episteme is not a form of cognition or a type of rationality that, when intersecting with various sciences, would express the sovereign unity of the subject, spirit, or the epoch: it is the totality of relations that can be opened to a given era between the sciences when we analyze them in levels of language patterns. M. Foucault emphasized that the episteme is an infinitely moving figure, and its description can never be completed $^{26}$.

In the context of nomination of epistemological foundations, it is important to understand the structure of historical and pedagogical knowledge. One of the few publications on this issue is an article by Russian scientist M. Boguslavskyi ${ }^{27}$. It presents a four-part construct of the structure of historical and pedagogical knowledge: 1) worldview position in the interpretation of the phenomena of the past (materialistic-deterministic, transcendental (religious), synergistic worldview); 2) the scope of general approaches to the study of world history of education (formational, anthropological, civilizational approaches); 3) general research methods (historical-structural, structural-genetic, historical-comparative methods); 4) partial research methods (axiological, large innovation schemes, wave, modernization, monographic, paradigmatic).

Such way of structuring of scientific historical and pedagogical knowledge seems to us insufficiently substantiated, as it is very similar to the structure of the methodology of scientific research: firstly outlook, then philosophical approaches (and the latter can determine outlook), and finally, specific methods and techniques. In addition, such construction raises the questions about the lack of a specific scientific level of methodology, represented by regional, paradigmatic, biographical approaches, etc. in this scheme. Among the general (philosophical) approaches the scientist did not mention hermeneutical, phenomenological, ontological and others. Granting by Boguslavskyi the synergistic, generalscientific approach a world-view status seems doubtful. It is not quite clear the characteristic of the methods: special-historical methods (historical-

\footnotetext{
${ }^{26}$ Фуко М. Археологія знання. Київ : Вид-во Соломії Павличко «Основи», 2003. С. 298.

27 Богуславський М. Структура сучасного історико-педагогічного знання. Шлях освіти. 1999. № 1 (11). С. 37-40.
} 
structural, historical-genetic, historical-comparative) the scientist refers to the general methods of a research, but for some reason forgets about the analysis, synthesis, generalizations and other, actually general methods of any scientific research. After all, it is unclear why axiological, paradigmatic approaches are among the "partial methods" and in the status of "methods".

Of course, there is no denying that any methodological approach is the part of epistemology (as well as gnoseology). The knowledge of methods is also knowledge, so it is entirely within the field of epistemology, and the use of methods for obtaining certain knowledge puts the content of gnoseological procedures, which can be interpreted as a procedural and dynamic component of knowledge, and therefore again to be included in the field of the interests of epistemology.

However, M. Boguslavskyi's vision of the structure of knowledge in a predominantly dynamic plane is still inferior to the vision of the structure of knowledge largely in a static dimension. The actual isolation of the structure of a particular phenomenon requires fixing it as an established phenomenon. For this reason, we prefer the traditional division of knowledge into two structural components: 1) extracurricular knowledge a set of knowledge (ideological, professional and even household) and values (moral, national, civic, etc.) of a researcher which predetermine the scientific questions, the formulation of problems, selection of sources, and thus have a decisive influence on the construction of the historical and pedagogical past. The components (and thus the epistemological foundations) of this component are: ideologic-philosophical, politicalideological, socio-cultural, interdisciplinary and disciplinary, instrumental and methodological knowledge; 2) source knowledge - knowledge separated from historical (historical and pedagogical) sources by means of scientific and methodological tools and presented by historical and pedagogical facts. The very methodology of the source criticism belongs to the extra-original component of knowledge, but its application allows a researcher to form source knowledge, which is often nominated by the notion of "fact" and is certainly the epistemological basis of the narrative.

The notion of "narrative" ("narration") is one of the major terminological innovations of postmodern philosophy of science to modern humanities. In philosophical dictionaries, "narrative" is largely defined as the notion of philosophy of postmodernism, which captures the procedural process of self-realization as the way of text being ${ }^{28}$. As L. Vakhovskyi points out, narrative in the context of historiography interprets the meaning of a historical event not as a historical process conditioned by objective

\footnotetext{
${ }^{28}$ Новейший философский словарь. Минск : Книжный Дом, 2003. С. 656.
} 
regularity, but as narrative arising in the context of an event and inherently related to the interpretation. So, according to the concept of "narrative history", history is not what it really was in the past, but what we tell about the past is a story about the past ${ }^{29}$. Narrative, therefore, is a textual form of knowledge being.

The notion "Ukrainian historical and pedagogical narrative" is defined as the totality of historical and pedagogical heritage (metatext) of the researchers of the past of education and pedagogical thought who resided in the territory of Ukraine or abroad within the Ukrainian diaspora. Considering that the Ukrainian lands in the studied era belonged to the number of foreign states, the only possibility to outline the affiliation of pedagogical historians to the "Ukrainian historical and pedagogical narrative" is the vision of the Ukrainian historical and geographical space through the prism of modern political borders. In this case, the principle of territoriality is crucial, instead the notion of ethnicity and even national identity of the historian of pedagogy becomes less important. Therefore, the texts of not only ethnic Ukrainians, but also the scholars of other nations have to be included in the "Ukrainian historical and pedagogical narrative". Among them, two cohorts of pedagogical historians should be distinguished: 1) those who identified themselves with the Ukrainian people (eg, S. Rusov), 2) those who identified themselves with Russian, Polish, or any other people, but who lived in Ukraine for a long time also revealed certain regional (local-regional) identity (A. Vanchura, S. Golubjev, F. Titov, etc.). In the case of the representatives of the Ukrainian diaspora, the only way of referring the scientist's works to the "Ukrainian historical and pedagogical narrative" is precisely the Ukrainian national identity of the author of the texts. Therefore, the national historical and pedagogical narrative acts as an imagined cultural and scientific phenomenon, reconstructed on the basis of biographical, historiographical, historical facts, constructed on the basis of gravity, cumulativeness, paradigmality, holicity, coherence, functionality and distinguished territory and identity markers.

As the notion of "pedagogy" is interpreted in the broadest sense of the word, we also interpret the history of pedagogy as: a) the past not only of pedagogy-science, but also for pedagogy-sphere of social life, represented by the realization of pedagogical experience, education of the younger generations; b) presented in the scientific and popular science narratives of the study of the past. That is why we include the works on the history of education and schooling, the history of pedagogical thought, and

${ }^{29}$ Ваховський Л.Ц. Наратив у історико-педагогічному дослідженні: методологічний аналіз. Шлях освіти. 2007. № 1. С. 43. 
pedagogical personality into the "Ukrainian historical and pedagogical narrative".

\section{CONCLUSIONS}

Thus, the theoretical and methodological foundations of the study included general scientific (axiological, synergistic, paradigmatic, hermeneutic, sociocultural, civilizational and phenomenological), specifically scientific (narrative, imaginary, biographical and prosopographic, synchronic diachronic, limological, systemic, complex) approaches and applied mechanisms (general scientific, interdisciplinary and special historical methods). The definitions of "epistemological foundations", "narratives", "Ukrainian historical and pedagogical narratives" are given in the work.

\section{SUMMARY}

The section identifies the methodological foundations of the study of the epistemological foundations of the Ukrainian historical pedagogical narrative (mid-nineteenth and late twentieth centuries), which relied on general scientific, specific scientific, and instrumental and applied levels of methodology. The general scientific level is to combine the basic epistemological foundations of the analytical and narrative philosophy of history and axiological, synergistic, paradigmatic, hermeneutic, sociocultural, civilizational and phenomenological approaches. The specific scientific level is represented by narrative, imaginary, biographical and prosopographic, synchronic-diachronic, lymological (regional), systemic and complex approaches, as well as the combination of the principles of historicism, scientificity, objectivity and multifactoriality. The instrumental and applied level is represented by the application of general scientific (abstraction, analysis and synthesis, induction, deduction, classification, generalization), interdisciplinary (contextual-interpretative, cognitive mapping, lexico-semantic and logical-semantic, critic, structural-systemic) and specific historical (historical-genetic, historical-comparative, historical-typological, historical-systemic, periodization, retrospective) research methods. The section defines the notions "epistemological foundations" and "Ukrainian historical and pedagogical narrative".

\section{REFERENCES}

1. Бєлан Г.В. Біографічний метод в історико-педагогічній науці: провідні тенденції становлення. Педагогічний дискурс. 2013. Вип. 15. С. 50-54. 
2. Богуславський М. Структура сучасного історико-педагогічного знання. Шлях освіти. 1999. № 1. С. 37-40.

3. Ваховський Л.Ц. Наратив у історико-педагогічному дослідженні: методологічний аналіз. Шлях освіти. 2007. № 1. С. 42-45.

4. Верменич Я. Нова локальна історія та історична регіоналістика: експлікація термінів. Регіональна історія Украйни. 2010. Вип. 1. C. $13-19$.

5. Гадамер Г.-Г. Істина і метод. В 2 т. Київ: Юніверс, 2000. Т. 2. $500 \mathrm{c}$.

6. Данто А. Аналитеческая философия истории. Москва: Идеяпресс, 2002. 290 с.

7. Іванишин П. Національно-екзистенціальна інтерпретація (основні теоретичні та прагматичні аспекти). Монографія. Дрогобич: "Відродження", 2005. 308 с.

8. Коваленко Є.I. Методологічна функція історії педагогіки у становленні майбутнього педагога. Наукові записки Ніжинського державного університету ім. М. Гоголя. Серія: Психолого-педагогічні науки. 2012. № 4. С. 27-34.

9. Корнетов Г.Б. Теория истории педагогики: монография. Москва: АСОУ, 2013. 460 с.

10. Кун Т. Структура научных революций. Москва: Прогресс, 1977. $300 \mathrm{c.}$

11. Куций I. Цивілізаційні ідентичності в українській історіографії кінця XVIII - початку XX ст.: між Слов'янщиною та Європою. Тернопіль, 2016. 480 с.

12. Лекторский В.А. Реализм, антиреализм, конструктивизм и конструктивный реализм в современной эпистемологии и науке. Конструктивистский подход в эпистемологии и науках о человеке. Москва, 2009. С. 5-40.

13. Нагорна Л.П. Соціокультурна ідентичність: пастки ціннісних розмежувань. Київ, 2011.272 с.

14. Новейший философский словарь. Минск: Книжный Дом, 2003. $1280 \mathrm{c}$.

15. Петрушенко В.Л. Епістемологія як філософська теорія знання. Львів: Вид-во ДУ “Львівська політехніка”, 2000. 295 с.

16. Рупташ О.В. Парадигмальний підхід у гуманітарних науках. Нова парадигма. 2014. Вип. 122. С. 20-32.

17. Сухомлинська О. Історико-педагогічне дослідження та його “околиці”. Шлях освіти. 2005. № 4. С. 43-47.

18. Сухомлинська О. Історико-педагогічний процес в Україні: регіональний вимір. Шлях освіти. 2007. № 2. С. 42-49. 
19. Сухомлинська О.В. Історико-педагогічний процес: нові підходи до загальних проблем. Київ : А.П.Н., 2003. 68 с.

20. Топольський С. Як ми пишемо і розуміємо історію: Таємниці історичної нарації. Київ: К.І.С., 2012. 400 с.

21. Удод О. А. Аксіологічний (ціннісний) підхід у методології та методиці історії. Наукові праці історичного факультету Запорізького державного університету. 2000. Вип. XI. С. 164-173.

22. Філософський енциклопедичний словник. Київ: Абрис, 2002. $742 \mathrm{c}$.

23. Фуко М. Археологія знання. Київ: “Основи”, 2003. 326 с.

24. Domańska E. Mikrohistorie. Spotkania w międzyświatach. Poznań: Wydawnictwo Poznańskie, 1999. 337 s.

\section{Information about the author:}

Haliv M. D.

Candidate of Pedagogic Sciences, Associate Professor at the Department of History of Ukraine, Ivan Franko Drohobych State Pedagogical University 24, I. Franko str., Drohobych, Lviv region, 82100, Ukraine 


\section{THE CREATIVE INTERACTION OF BELARUSIAN AND UKRAINIAN CULTURAL LEADERS AT THE AGE OF NATIONAL REVIVAL}

\section{Hrytsenko H. Z.}

\section{INTRODUCTION}

The peculiarity of inter-Slavonic relations at that time consisted in the political position of the Slavonic peoples, deprived of statehood, gave rise to the idea of Slavonic reciprocity. The Slavonic idea branched off into many variants, but in all its manifestations was utopian: the historical conditions of the existence of each Slavonic people had always been stronger than that idea. However, it influenced the nature of inter-Slavonic cultural ties significantly. The culture that expressed a higher degree of national consciousness, the bearers of this culture generated patriotic sentiments in the neighbors, intensified the processes associated with the formation of national cultures. These interdependent processes were extremely intense and were at the heart of a peculiar phenomenon of Slavonic national revival.

Therefore, it is important to explore Belarusian-Ukrainian relations in the field of education and science of the second half of the XIXth - the beginning of XXth centuries. After all, an important area of cultural contact was education, which was combined with scientific researches, stimulated the interest of local scholars, mainly in the fields of history, literature, folklore, and language.

The creative interaction of Belarusian and Ukrainian cultural figures brought a significant result, which was constantly enriched. The process of education of many representatives of Belarusian culture on the territory of Ukraine was of great importance. Thus, in Belarus in the nineteenth and early twentieth centuries the number of higher education institutions did not meet the needs of the population. The Belarusian artists who studied in Ukraine not only received serious training but also worked in Ukraine, and subsequently initiated the organization of local art education.

The interaction of scientists was clearly manifested in the field of humanities - history, ethnography, folklore and linguistics, great attention was paid to the life, oral folk art of Ukrainians and Belarusians. Belarusian scientists were interested in the works of their Ukrainian colleagues and reviewed their scientific publications in the periodicals. Ukrainians, in their turn, used Belarusian materials and introduced them to scientific use. 
For scientific and cultural interactions between Belarusians and Ukrainians, the publications in which Ukrainian and Belarusian materials stood side by side were of great importance. All this contributed to a deeper knowledge of the two Slavonic peoples, their pressing national problems.

The contacts of Belarusian scientists with Ukrainians created great opportunities for searching and introducing various source materials to the scientific circulation, facilitated the preparation of summarizing works, especially in the Slavonic sphere, made it possible to expand book-sharing, influenced the development of scientific research, etc.

The importance of the study of the topic is reinforced by the formation of a modern system of Belarusian-Ukrainian international relations, the rapprochement of their cultures, which is of great socio-political importance. The absence of generalizations or special works in Belarus and Ukraine, as well as in other countries that would cover most aspects of bilateral cultural relations, reinforces the relevance of the study of the topic outlined. Therefore, the comprehensive research and creative use of the accumulated experience of cooperation and exchange of cultural values will contribute to the enrichment of modern science.

\section{Educational relationships}

According to the census in 1897, the literate population on Belarusian lands was only $25.7 \%$ of the total population. In addition, according to the census, a considerable part of Ukrainians lived on the territory of Belarus. In particular, in Grodno province, Ukrainians made up $22.6 \%$ of the total population, including Kobryn county $-79.6 \%$, Beresteiskyi $-64.4 \%$, and Bielskyi $-39.1 \%$.

Thus, in the second half of the nineteenth century a well-known Belarusian writer, one of the founders of new Belarusian literature, Frantisek Bogushevych (1840 - 1900) studied in Ukraine. An active participant of the Polish uprising of 1863, avoiding repression, he secretly moved to Chernihiv region, where he had been living in Nizhyn, Chernihiv, Konotop for 15 years. On May 29, 1865 F. Bogushevych became a student of Bezborodko Law Lyceum (in 1875 it was renamed into Nizhyn Historical and Philological Institute).

In 1868, F. Bogushevych graduated from the Lyceum as a 12th grade official and got a job in Chernihiv. On November 26 of the same year, he wrote to the Chernihiv vice-governor: "Until December 1, I am on the service in the local administration" $"$. He was appointed an ordinary clerical

\footnotetext{
${ }^{1}$ Народное образование и культура в БССР: Статистический сборник. - М., 1989. - С. 325-326.

${ }^{2}$ Державний архів Чернігівської області. - Ф. 140. - Оп. 1. - Спр. 141. - Арк. 46.
} 
officer, and therefore filed a note of appointment of the rank of provincial secretary, according to his education. This request was granted and F. Bogushevych was transferred to the Chernihiv Chamber of Criminal and Civil Court, appointing a candidate for the post of judicial investigator. $\mathrm{He}$ was recently appointed Acting Investigator of the First Precinct of Borzenskyi District. He was a conscious defender of the interests of Ukrainian peasants.

During 1874 and until 1883 F. Bogushevych served in the judicial bodies of Konotop. The young lawyer, in his practice with many people, always tried to protect their interests. The Ukrainian historian O. Lazarevskyi, the writer P. Kulish, the military writer and theorist M. Dragomyrov lived there. So the investigator F. Bogushevych had the opportunity to communicate with, to align himself. Fifteen years later he returned to his hometown Vilno ${ }^{3}$.

In 1881-1885 the student's life of Yukhim Karskyi (1860-1931), a native of Hrodno, began in Nizhyn. The son of a village clergyman, he graduated from the Minsk Seminary and, in pursuit of higher education, chose Nizhyn Historical and Philological Institute. At the Slavonic-Russian Department, under the supervision of professor R. Brandt, his journey into science began. The first student scientific work "The peculiarities of spelling and language of Suprasl manuscript" was highly appreciated, as was reported in the collection "The News of Nizhyn Bezborodko Historical and Philological Institute" ". Yu. Karskyi informed about the successful defense of his master's thesis at St. Vladimir's University in the letter to the ethnographer P. Shein (1893). "I was received in a friendly way in Kiev, probably because I met many of them at the congress in Vilno, in particular, Antonovych, Vladymyrov ... My dispute went well",5.

Yu. Karskyi was a researcher in Slovonic languages, ethnographer, folklorist, language historian, founder of Belarusian linguistics and literary studies. He is the author of over a thousand scientific papers, reviews, notes.

The well-known Belarusian historian, public figure Mytrofan DovnarZapolskyi (1867-1934) studied at the educational institutions of Kyiv. In 1885, when he studied at the First Kiev High School, he made his debut as a writer. Kyiv life only contributed to the development of the chosen direction and the formation of independence. His small notes on the life of

\footnotetext{
${ }^{3}$ Ильин А. Франтишек Богушевич и Конотопщина // Нёман. - 2000. - № 3. - С. 247-250.

4 Извлечение из протоколов Конференции Института за $1883 / 84$ учебный годъ // Известия историко-филологического института князя Безбородка в Нежине 1883 - 1884. - М. - К., 1885. - Т. 9. C. $126-129$.

${ }^{5}$ Карский А. Академик Карский. Страницы книги // Нёман. - 2011. - № 8. - С. 153.
} 
Kiev were printed in the newspapers "Zorya" (Kyiv) and "Vylenskyi Vesnik".

In February 1888, at the apartment of M. Dovnar-Zapolskyi, a high school inspector found the forbidden to distribute by tsarist government literature, namely the works of M. Drahomanov, M. Kostomarov's letter to A. Herzen, the poem of T. Shevchenko "Maria". This was the reason for his expulsion from the gymnasium two months before the final exams ${ }^{6}$.

The document on the completion of high school education was obtained the following year by M. Dovnar-Zapolskyi: during April - June 1889 he had been taking the exams in 10 subjects at the Fourth Kiev Gymnasium and received a certificate of maturity. His knowledge was assessed as "satisfactory" in 8 subjects, he had not passed the exam in German and received "good" in history".

The following year, he entered St. Vladimir's University, the Department of History and Philology, was studied by the renowned Ukrainian historian V. Antonovych, on the recommendation of which a young scientist was left at the university to prepare for the professorial title. In 1891 M. Dovnar-Zapolskyi published works on historical subjects. One of them concerned the history of Kryvychi and Dregovychi until the end of the XIth century ${ }^{8}$. The second work covered the history of the Grand Duchy of Lithuania and was already directly related to his master's work ${ }^{9}$.

Many immigrants from the territory of modern Belorussia sought spiritual education at Kyiv Theological Academy (KTA), which was considered a prestigious educational institution, and remained in Ukraine while continuing pastoral service. These include the famous historian, teacher, doctor of History, Professor Ivan Malyshevskyi (1828-1897). In 1870-1874 the famous historian Stepan Golubev was a student of KTA. It was I. Malyshevsky that interested him in the history of Church in Ukraine. The course of history of Church by Professor I. Malyshevskyi included general provisions on science and its sources and a systematic review of material from the time of the first Metropolitan Michail to the time of Catherine $\mathrm{II}^{10}$.

\footnotetext{
${ }^{6}$ Купченко В. Маловідомі сторінки біографії М. В. Довнар-Запольського // Ювілейна сесія до 40-річчя від дня народження М.В. Довнар-Запольського. [Збірник]. - Гомель, 2007. - С. 27-28.

${ }^{7}$ Купченко В. Архивные документы о гимназических годах М.В. Довнар-Запольского // Чацвёртыя Міжнародныя Доўнараўскія чытанні: Рэчыца, 18 - 19 вересня 2003 р. - Гомель, 2004. - С. 25.

8 Довнар-Запольский М.В. Очерк истории кривичской и дреговичской земель до конца XI столетия / М. Довнар-Запольский. - К., 1891. - 170 с.

9 Довнар-Запольский М.В. Государственное хазяйство Великого княжества Литовского при Ягеллонах. - К., 1901. - VIII, 807, CXII с.

10 Ульяновський B.I. Двічі професор: Степан Голубєв в університетському та академічному контекстах. - К., 2007. - С. 34.
} 
It should be noted that it was S. Golubev who responded with respect about I. Malyshevskyi, who remained for him almost the only authority in "real life""

I. Malyshevskyi was a valid and honorary member of many scientific organizations, the author of numerous scientific works and a supporter of Slavonic cultural unity. His life journey ended in Kiev, where he was buried $^{12}$.

In the early twentieth century the well-known Belarusian poet Yanka Zhurba (real name - Ivan Ivashyn, 1881-1964) studied in Ukraine. After graduating from the Polotsk Teacher's Seminary (1902) and several years of work in the primary schools of Vitebsk province, Ya. Zhurba, wishing to obtain higher education, entered Hlukhiv Teacher's Institute in 1906. During his studies he became a member of the Ukrainian illegal group, in which his students studied Ukrainian literature, and also discussed specific political issues. The participation in such unions aroused the feeling of national consciousness not only in Ya. Zhurba, but also in other Belarusian students ${ }^{13}$. Therefore, when the newspaper "Nasha Nyva" appeared in the walls of Hlukhiv Teachers' Institute, Belarusian students immediately created their own, also illegal, Belarusian union. This newspaper emphasized that "education must be inextricably linked with the soul of a Belarusian, it should develop and enrich him, not cripple, and for this it should be based on the national foundation"14. In one of the letters to the newspaper "Nasha Nyva", the poet Ya. Zhurba wrote: "In the case of the national school, we need to learn from our neighbors, Ukrainians, who have been extensively working for the nationalization of the school for a long time. But this work has grown most in recent years. Scientists from different schools, and vice versa, the simple rural Ukrainian people, have long been demanding their national school with requests, petitions, and needs" $"$.

In 1913, Ya. Zhurba entered Higher Commercial Courses in Kharkiv. However, the savings collected during his teaching years ended quickly and, after studying for over a year, the poet returned to a full-time job in Minsk province.

Taking the example of Ukrainians, Belarusian students created their own union, "the Belarusian National Hebra" (a union of students at Hluhiv Teachers' Institute), headed by Ya. Zhurba. The ideas of the union were self-education in the Belarusian spirit and spreading the idea of a national

\footnotetext{
${ }^{11}$ Там само. - С. 38.

12 Голубева Н. Беларусы Украины // Беларускае замежжа. - Мн., 2010. - С. 172-175.

${ }_{13}$ Максім Багдановіч. Энцыклапедыя / [под. рэд. М. В. Труса]. - Мн., 2011. - С. 219.

143 нашого жыцьця // Наша ніва. - 1910. - № 36. - С. 547-548.

15 Журба Я. Лісты з Украйны II. Клапоты аб національнай школе. - С. 211-212.
} 
Belarusian school. In order to achieve this goal, it was planned to support the Belarusian movement for the national school, read lectures on national affairs, seek Belarusianisation of the school and so on ${ }^{16}$.

Another Belarusian cultural figure who studied in Ukraine was a correspondent of the newspaper "Nasha Nyva", a writer and critic Serhyi Poluyan (1890-1910) ${ }^{17}$. He received his higher education at the University of Kiev in 1908. Together with Ya. Zhurba, he published materials on the cultural life of Ukraine in "Nasha Nyva" under the heading "Letters from Ukraine" (the total number 12) ${ }^{18}$. In one of the letters S. Poluyan wrote that "Kyiv can and should become (as long as we do not have higher schools in Belarus where our youth could study without leaving their native land) one of the centers of Belarusian national work"19. "Regarding that fact what our Ukrainian brothers have come to, one begins to believe that Belarusians and our mother tongue will not perish"20. S. Poluyan collaborated in Kyiv with the magazine "Ukrainska Hata" ("Ukrainian House"), around which young writers of the nationalist movement P. Bogatskyi, G. Chuprynka, M. Yevshan, M. Shapoval and others grouped.

The name of a well-known Belarusian bibliographer, literary critic, translator Romuald Zemkevych (1881-1944) is associated with Lviv ${ }^{21}$. During his studies at Lviv Polytechnics in the 1900's, he translated the novels of V. Stefanyk. Subsequently R. Zemkevych came to the city to work in libraries and archives. In 1909-1911 the works of V. Stefanyk "Death", "A Blue Book", "Evening Time", "A Dream" and others were published in "Nasha Nyva". In order to circumvent censorship, the translator R. Zemkevych and the newspaper's editors changed the titles of individual stories. The poet was subscribed to "Nasha Nyva", had close links with its editorial board and, since 1909, was regularly published in it. It is known that R. Zemkevych studied at Kiev Polytechnic Institute for some time. This is evidenced by his letter to an unknown addressee, written on March 21, 1909: "I am a student of Kiev Polytechnics, I work as a mentor in the family of Mykhailo Svyantsitskyi in Kazimirov. In addition to mentoring, I practice Belarusian ethnography here in my free time ..."22.

\footnotetext{
${ }^{16}$ Ільін А., Гарбачык М. Нацыянальнае адраджэньне пачатку XX ст. : беларуска-ўкраінскія повязі // Спадчына. - 2000. - № 2. - С. 50.

17250 асоб з Беларусі у дыялогах культур / [ред.: Т. Л. Пісарэнка, Л. У. Языковіч]. - Мн., 2008. C. $180-181$.

${ }^{18}$ Из истории школы Белорусии и Литвы / [под ред. Смирнова С. И.]. - М., 1964. - С. 124.

19 Журба Я. Лісты з Украйны VII. - С. 229-230.

${ }^{20}$ Полуян С. Лісты з Украйны IX. - С. 493.

${ }^{21}$ Из истории школы Белорусии и Литвы / [под ред. Смирнова С. И.]. - М., 1964. - С. 182.

22 Скрыжалі памяці: 3 творчай спадчыны пісьменнікаў Беларусі, якія загінулі ў гады Другой сусветнай вайны. У 3 кн. Кн. 2 / [уклад., біягр. давед. пра аўт. і камент. А. Бельскага]. - Мн., 2005. C. 396.
} 
Many Belarussians studied in Lviv educational institutions, including the poetess Tzotka, real name - Aloiza Pashkevych (1876-1916).

A. Pashkevych attended classes of the history of ancient Polish language and literature, read by Professor V. Bruhnalskyi for nine semesters, at Lviv University.

However, it is known that the Austrian Ministry of Education allowed A. Pashkevych to become a full-time student of Lviv University and on July 29, 1912, sent a corresponding document to Lviv. As noted by L. Arabai, a researcher of social and cultural activity, scientific work and artistic creativity of Tziotka, her student ID was preserved in one of the Lithuanian archives. In the form of a photograph, she placed this document in her book. It shows that the ID has registration number 4599, dated September 26, 1912, and signed by Professor V. Bruhalskyi ${ }^{23}$.

At this time Tzotka works a lot. She listens to lectures at the university and is also self-educated: she studies Ukrainian, German and Czech. In evenings, she works at the Ossolinskyi Library, studying history, ethnography, folklore of Poland, Ukraine, Belarus, Lithuania.

The permission to enroll as a full-time students came from the ministry on July 29, 1912, and the expected study began. When filling out a special student card in the dean's office, A. Pashkevych always indicated "Belarusian" in the "native language" column. A. Pashkevych studied at the university only for one semester of 1912/1913. After her graduation, she went to visit her native land and, for unknown reasons, never returned to Lviv $^{24}$.

In Belarus in the nineteenth and early twentieth centuries there were no special music and art schools. Therefore, the youth were forced to travel to other lands where there were conservatories and art schools. In particular, such educational institutions were in Ukraine. Since 1865 the art school was in Odessa, in which the Belarusian artist Lev Alperovych (1874-1913) received his professional education. In 1869 M. RayevskaIvanova opened the first art school in Kharkiv, which was later reorganized into a college. In $1875 \mathrm{M}$. Murashko founded Kyiv Art School, where many Belarusian artists studied ${ }^{25}$. In particular, there in 1883 studied the Belarusian artist Yakov Kruger (1869-1940). There his art education received the Belarusian landscape painter Vitold Bialynytskyi-Birulya (1872-1957), who later became a well-known artist and member of the Association of Mobile Exhibitions (1904). His most famous canvases, created in the early twentieth century: "Eternal snows",

\footnotetext{
${ }^{23}$ Арабей Л. Цётка (Алаіза Пашкевіч). - Мн., 1956. - С. 25.

${ }^{24}$ Ільін А., Гарбачык М. Нацыянальнае адраджэньне пачатку XX ст. : беларуска-ўкраінскія повязі // Спадчына. - 2000. - № 2. - С. 52.

${ }^{25}$ Дробаў Л. Н. Беларускія мастакі ХІХ стагодзя. - Мн., 1971. - С. 68.
} 
“A Spring Day", “Autumn", "Spring”. In 1908 he was awarded the title of Academician of $\mathrm{Art}^{26}$.

One of the first who attemped to open an art school in Minsk was V. $\mathrm{Maas}^{27}$, who worked at Odessa Engineering Department and at the same time at Odessa Art School. He took it as the example of the school that Maas decided to organize in Minsk. In order to collect money for the school, in $1891 \mathrm{~V}$. Maas organized the first local art exhibition in Minsk ${ }^{28}$. However, because of the lack of money, the Belarusian artist opened an art carpentry workshop, percentage of the proceeds of it was to be credited to a future institution's fund. After two years of work, the workshop was also closed.

Another attempt of a graduate of Kyiv Art School, Ya. Kruger turned to be more successful, who opened drawing and painting courses in Minsk in 1904, which were later reorganized into a private art school. At the end of the nineteenth century there were other private schools in Belarus, including Ya. Katsenbogen's in Minsk, and Yuri Pen's Painting School (1854-1937) in Vitebsk ${ }^{29}$.

An important field of educational relations was the pedagogical activity of Belarusians in educational institutions of Naddnipryanshchyna (the territory over the Dniper). The activity of M. Dovnar-Zapolskyi in Nestogor-Chronicler Society is evidenced by the statement of the trustee of Kyiv Educational District to the head of the Society dated back to November 8, 1902. "With the proposal to exclude historical lectures from the program of the public course, organized by the society, of Belarusian professor M. Dovnar-Zapolskyi in the period from November 1902 to March 1903"30.

In Kyiv, in 1906 M. Dovnar-Zapolskyi succeeded in establishing a private higher education institution of economics - Kyiv Higher Commercial Courses. M. Dovnar-Zapolskyi became the first rector of this institution and invariably headed it until March $1917^{31}$. Under the leadership of this scientist, Ukrainian scientist P. Klymenko also specialized in the history of the Lithuanian-Russian state ${ }^{32}$.

In 1899, having successfully passed the exams, he entered the classical gymnasium at Bezborodko Institute of History and Philology.

\footnotetext{
${ }^{26}$ Кацер М. Изобразительное искусство Белоруссии. - Мн., 1969. - С. 150.

27 Дробов Л.Н. Живопись Белорусии ХІХ - начала XX веков. - Мн., 1974. - С. 136.

28 Исторические корни дружбы и единения белорусского и украинского народов / [под ред. Кондуфор Ю.Ю.]. - К., 1978. - С. 227.

29 Дробаў Л.Н. Беларускія мастакі ХІХ стагодзя. - Мн., 1971. - С. 68.

30 Національна бібліотека України імені В. І. Вернадського. Інститут рукопису. - Ф. 8. - Оп. 1. Спр. 3097. - 1 арк.

${ }^{31}$ Державний архів міста Києва (далі - ДАК). - Ф. 153. - Оп. 8. - Спр. 809. - Арк 57.

32 ДАК. - Ф. 16. - Оп. 164. - Спр. 2304. - Арк. 6.
} 
Already in 1908, P. Klymenko - a student of the historical department of the Faculty of History and Philology of St. Vladimir University ${ }^{33}$. Historical and Ethnographic Union at the University became a real scientific school in 1911 for P. Klymenko. He came to it with a desire to study economic history. M. Dovnar-Zapolskyi invited his talented student, whose term of tenure to be a professor's fellowship expired in June 1918, to read a course of lectures on Western Russian history at Kiev Archeological Institute.

It is known about the activity of the Belarussian union "A Star", which active figures were the future Belarusian historians Todor Zabello (1896 - 1935) and Lev Akynshevych (1898 - 1980) in Kyiv (1910). They were also students of M. Dovnar-Zapolskyi. All this confirms that Kiev period was the longest and most fruitful in the life of the scientist.

After graduating from the Hluhiv Teachers' Institute (1911), he worked as a teacher in Poltava region for a while and at the same time continued his literary activity a Belarusian poet Ya. Zhurba. This indicates that there were many Belarusians who studied history, culture of their native land and spread their knowledge among Ukrainians.

The next step in the reform of the education system was the opening of women's educational institutions. On May 26, 1869, the regulations on women's gymnasiums and grammar schools in Belorussian Vitebsk and Mogilev provinces were approved ${ }^{34}$.

Many graduates of higher education institutions from the territory of Ukraine worked in Belarusian grammar schols. During the second half of the 1880s - early 1900s, they held prominent positions in Vitebsk and Mogilev Classical Grammar Schools ${ }^{35}$. In particular, at Vitebsk men's and women's classical gymnasiums a teacher Z. Oshpov, candidate of history and philology department of Kharkiv University; I. Nerush and M. Basangin, graduaters of Nizhyn Historical and Philological Institute taught history and geography. Notable figures in Mogilev gymnasium were the teachers of history and geography P. Savych, G. Gortynskyi, V. Lyubarskyi and others. They were the graduaters of Kiev St. Volodymyr University. This indicates that the graduaters of higher education institutions from the territory of Naddnipryanshchyna region facilitated the establishment of the educational process, spreading their knowledge among Belarusians.

\footnotetext{
${ }^{33}$ Там само. - Арк. 5.

${ }^{34}$ Антошко М. Розвиток освіти на Поділлі кінця XIX - першої половини XX століття // Теоретичні питання культури, освіти та виховання : збірник наукових праць. - К., 2008. - Вип. 36. - С. 8.

35 Памятные книжки белорусских губерній [Электронный ресурс] / Национальная библиотека Беларуси. - Мн., 2012.
} 
During 1877-1887 the Ukrainian teachers P. Sander and Ya. Danylov worked in Slutsk Classical Men's Gymnasium. According to the memoirs of Belarusian public figure Napoleon Charnotskyi, who studied in the third grade of the gymnasium, P. Sander and Ya. Danylov held secret meetings with the students, at which they read T. Shevchenko's "Kobzar" and M. Drahomanov's works ${ }^{36}$.

The Belarusian-Ukrainian relations in the field of education were, in fact, quite one-sided, due to the difficult situation in Belarusian schooling (there was no university) and the comparatively better developed system of education in the Ukrainian lands. Many immigrants from Belarus studied at Nizhyn Institute, Lviv, Kharkiv, Kyiv Universities. During their educational and scientific studies Belarusian students and scientists were able to get acquainted with the real life of Ukrainian people, to compare their situation with the situation of Ukrainians. All this gives reason to speak about the solid basis on which the relations in the field of education, science and literature subsequently developed.

\section{Scientific contacts}

Maxim Bogdanovych played a leading role in the development of scientific relations. He was born on December 9, 1891 in Minsk in the family of an ethnographer. He was educated at Nizhnyi Novgorod and Yaroslavl grammar schools (1902-1911) and Yaroslavl Law Lyceum $(1911-1916)^{37}$. As a student of Yaroslavl Lyceum, he joined the union, where he got acquainted with professor B. Kistyakivskiy, a Ukrainian. The union organized meetings, at which the reports on Slavonvic studies were proclaimed, literary works were read, and folk songs were sung ${ }^{38}$. M. Bogdanovych is the author of a number of works on the history and literature of Ukraine, the best of which occupy a leading place in Belarusian science and journalism. In addition, M. Bogdanovych was so good at Ukrainian that some of his works were written in Ukrainian.

M. Bogdanovych' attention to Ukraine, its history, culture at the beginning of the twentieth century is explained by the stateless position of the Ukrainians and Belarusians, their liberation competition. M. Bogdanovych began to deal with the problem of sub-Austrian Ukrainians under the influence of professor B. Kistyakivskyi. It was in his library where the writer found the necessary sources, on the basis of which he wrote his first historical, ethnographic and literary essays. Among them

\footnotetext{
${ }^{36}$ Czarnocki N. Wspomnienia (Nauczyciele Ukraińcy w Slucku) // Biuletyn Polsko-Ukraiński: tygodnik ilustrowany. - Warszawa, 1934. - № 6. - S. 2-3.

${ }^{37}$ Максім Багдановіч. Энцыклапедыя / [под. рэд. М. В. Труса]. - Мн., 2011. - С. 10.

38 Пігуляк М. Максим Богданович і Західна Україна // Радянське літературознавство. - 1964. № 5. - C. 124 .
} 
were "Ukrainian Cossacks", "Galician Rus", "Hungarian Rus", "Red Rus", "Lviv", "Austrian Ukrainians", and literary studies - "The Forgotten Way", "The Images of Galicia in Fiction", etc ${ }^{39}$. He made an attempt to acquaint the broader Belarusian public with different aspects of the historical-ethnographic, folk-poetic and literary life of Ukrainians in Austrian state with the help of these works. In this area, M. Bogdanovych acted as an active spokesman for the Belarusian-Ukrainian cultural union.

Based on specific material, M. Bogdanovych proved that Ukrainians have a full right for self-development, as they created a rich and glorious history, and glorified the heroic past of the Ukrainian people ${ }^{40}$. It should be noted that all articles were written at the beginning of the First World War, when the attention of the Russian public focused on Galicia as a bridgehead. In the condition of social and national oppression of the Slavonic peoples, he was concerned about the struggle for their selfdetermination. He never separated an ethnographic group into a separate nationality, constantly keeping in view the ethno-spiritual integrity of Ukrainianness $^{41}$.

In their turn, Ukrainian writers and literary critics, who spoke warmly about the personality and creativity of this famous Belarusian poet, did not remain in debt. According to the Ukrainian writer M. Dray-Khmara, he is an outstanding master of a word, who "heard all the manifestations of the national and social liberation of the Belarusian people; with extreme love he treated Ukrainian culture in general, spoke publicly in defense of the assaulted Galicia ... was published in our journals, studied our writing, language, wrote about our writers, translated their works, and even tried to write Ukrainian poetry" ${ }^{\prime 2}$. Similar views were expressed by I. Krypiakevych in the research "Belarusians". He stressed that M. Bogdanovych treated Ukrainians with great sympathy ${ }^{43}$.

It should be noted that the name of not only M. Bogdanovych, but also the famous researcher, Belarusian Arseniy Markevych (1855-1942), a native of Brest-Litovsk, is associated with the Crimea. He left the descendants the most complete study of the peninsula. From 1883 his life was connected with the Crimea, Simferopol, where he was not only engaged in teaching, but also carried out extensive research work, studying the ancient monuments of the peninsula. He was the author of the first scientific works devoted to the Crimea: "A trip to Old Crimea"

\footnotetext{
${ }^{39}$ Богданович М. Стратим-Лебідь. Збірник творів: поезія, проза, публіцистика, критика, листи [пер. 3 білорус. та рос. Р. М. Лубківський [та ін.]. - Л., 2002. - С. 191.

40 Богданович М. Угорська Русь. - Скрентон: 3 друкарнї “Народної волї”, 1916. - С. 11.

${ }^{41}$ Максім Багдановіч. Энцыклапедыя. - Мн., 2011. - С. 160.

${ }^{42}$ Національна бібліотека України імені В. І. Вернадського. Інститут рукопису. - Ф. 10. - Оп. 4. Спр. 17307. - Арк. 3.

${ }^{43}$ Крип'якевич І. Білоруси. - Л.: Накладом т-ва “Просвіта”, 1909. - С. 11.
} 
and "To the history of the Bakhchisarai Palace". The book for every Crimean researcher is his work "Taurika: the Experience of the Index of Works about the Crimea" (1894). On the initiative of A. Markevych, Tavriya University was created on the peninsula - the first higher educational institution of the Crimea, to which he handed over his rich library ${ }^{44}$.

The great Ukrainian writer Ivan Franko showed great interest in Belarusian literature. Some information about Ivan Franko's interest in Belarusian issues dates back to the 1880s. This is evident from his correspondence with the famous Polish writer E. Ozheshko ${ }^{45}$. In the letter dated March 20, 1886, Ozheshko asked I. Franko to provide her the information on a number of issues, the first of which was the issue of the territory of Belarus and Ukraine. On answering these questions, in the letter dated March 31, 1886, I. Franko pointed to some literature on Ukrainian studies, primarily on the works of M. Drahomanov. He stressed that "Drahomanov does not refer Belarus to Ukraine, but recognizes the right of Belarusians to independent national development ...". I. Franko, referring to the authority of $\mathrm{M}$. Drahomanov, shared his views on Belarusians as a separate people. Belarussians Kamenyar considered equal to Russians and Ukrainians ${ }^{46}$.

Honorary place was occupied by M. Dovnar-Zapolskyi in the galaxy of Slavists of the turn of the nineteenth - twentieth centuries. The Dnipropetrovsk researcher S. Abrosimova published two letters of M. Dovnar-Zapolskyi to the famous Ukrainian researcher of the history of Zaporizh Cossacks Dmitro Yavornitskyi (1855-1940) ${ }^{47}$. The first, dated 1902, referred to minor archival matters, and the second, dated October 3, 1905, to the 13th Archaeological Congress held the day before in Katerynoslav. M. Dovnar-Zapolskyi reported immediately the release of "The Book for Reading on Russian History" and suggested D. Yavornitskyi to write an article for the 2nd book about Zaporizh Sich and pointed to the main subjects that should be covered.

The number of Ukrainian correspondents of M. Dovnar-Zapolskyi is relatively small, but it includes the most authoritative representatives of Kiev School of History and Philology and Ukrainian Science. Among them are teachers of M. Dovnar Zapolskyi of Kyiv University and scientists -

\footnotetext{
${ }^{44}$ Голубева Н. Беларусы Украины // Беларускае замежжа. - Мн., 2010. - С. 173.

${ }^{45}$ Львівська національна наукова бібліотека України ім. В. Стефаника, відділ рукопис. - Ф. 82. Оп. 1. - Спр. 24. - Арк. 11-14.

${ }^{46}$ Мараш Я. История Белоруссии эпохи феодализма в интерпретиции Ивана Франко // I. Франко і світова культура: матеріали міжнародного симпозіуму. - К., 1990. - Кн. 1. - С. 120-122.

47 Епістолярна спадщина академіка Д.І. Яворницького. Листи вчених до Д. І. Яворнищького. Дніпропетровськ, 1998. - Вип. 1. - С. 265-269.
} 
V. Antonovych ${ }^{48}$, V. Ikonnikov ${ }^{49}$, P. Golubovskyi ${ }^{50}$. The correspondence with them is not only a valuable source for reconstruction of facts and events related to the scientific development of M. Dovnar-Zapolskyi, but also transferers the style of relations between teachers and students within Kiev school, as well as between representatives of different generations.

The contacts between M. Dovnar-Zapolskyi and M. Hrushevskyi were much stronger. This is due to various reasons, especially the same sociopolitical views, professional interests, and finally the peculiarities of the life path of both scientists. 18 letters of M. Dovnar-Zapolskyi to M. Hrushevskyi, written from Kiev, have been preserved. The largest in size and the most important are four dated back to 1895 and one 1896. M. Dovnar-Zapolskyi informs M. Hrushevsky about his painstaking work in the archives with the archaeographic publication "The Documents of the Moscow Archives of the Ministry of Justice" and, in particular, with the materials of the revision of Berest district 1566.

Five letters from M. Hrushevskyi to M. Dovnar-Zapolskyi and fifteen letters from M. Dovnar-Zapolskyi to M. Hrushevskyi during the period of cooperation with "Notes of NTS" were published in the collection "The correspondence of M. Dovnar-Zapolskyi with scientists of Ukraine (1893-1908)", was the result of the joint work of Belarusian and Ukrainian researchers ${ }^{51}$.

Among the researchers of this period, the first to mention is Ilarion Svyantsitskyi (1876-1956), a philologist, professor of Lviv University. I. Svyantsitskyi's ancestors came from Belarus, although he was born in Lviv region, he always considered himself a bit Belarusian. Perhaps this is one of the reasons for his continued interest in Belarusian history, language and literature.

During his visit to Belarus (1907), I. Svyantsitskyi personally met with Ya. Kupala and his poetry at the apartment of St. Petersburg professor of Belarusian studies B. Epimakha-Shypila. The following year, a Lviv scholar published a booklet entitled "The Revival of Belarusian Writing"52. It was not only the first work on Belarusian literature published abroad, but also the first in-depth study of Belarusian literature, beginning with the time of F. Skoryna's activity and ending with contemporary writings by I. Svyantsitskyi.

\footnotetext{
${ }^{48}$ Центральний державний історичний архів України, м. Київ (далі - ЦДІАК України). - Ф. 262. ОП. 1. - СПР. 159. - 5 арк.

${ }^{49}$ ЦДІАК. - СПР. 165. - 3 арк.

${ }^{50}$ ЦДІАК. - СПР. 162. - 41 арк.

51 Перапіска М. В. Доўнар-Запольскага з дзеячамі навукі Украіны (1893 - 1908 гг.). - Гомель, 2005. $-170 \mathrm{c}$.

${ }^{52}$ Свєнціцький І. Відродження білоруського письменства. - Л., 1908. - 62 с.
} 
As noted by the literary critic from Drohobych M. Shalata, there were several hundred editions in the library of Belarusian I. Svyantsitskyi ${ }^{53}$.

In the early twentieth century another Lviv scholar, a historian I. Krypiakevych, following I. Svyantsitskyi, began to become interested in Belarus. He has written many studies on the various issues of historical relations between Ukraine and Belarus. In 1909 in the printing house of Shevchenko Scientific Society was published his work "Belarusians",54, which he explored the issues of Ukrainian-Belarusian relations in the past.

The well-known popularizer of Belarusian literature was the famous Slavist V. Shchurat. In 1910 he published the article "Shevchenko Zheligovskyi - Chechot" in the journal "Dilo". In 1913 this text was published in his book "Literary Essays" " This indicates that the author was well acquainted with the Belarusian literary and folklore material.

Lviv scholars and writers have done much to familiarize Ukrainians with the history, culture and literature of the Belarusian people. It is quite reasonable to speak of the place of Lviv as a cultural center in the history of the Belarusian-Ukrainian unity.

The folklorist and ethnographer Volodymyr Hnatyuk (1871-1926) strongly opposed the humiliation of the Belarusian people. The researcher sharply criticized the well-known Belarusian writer-democrat and ethnographer M. Kosych for her writing about amorality of polischyks of Mozyr district and often called Belarusians "Lytvyns" in the writings "Lytvyns - Belarussians of Chernihiv province, their life and songs",56, "On the Belarussian Peasant's Buildings" (1906). The Ukrainian reviewer believes that the claim of M. Kosych is biased, that the folk name of the Belarusians "lytvyn" should not be introduced into scientific use without reservations, because it is mocking, offensive ${ }^{57}$.

V. Hnatyuk not only studied Belarusian folk art according to collections known at that time, but also dealt with its collection. He had close scientific ties with some Belarusian scientists ${ }^{58}$. This is evidenced by at least his letters to Y. Kars'kyi, discovered by M. Yatsenko in the Central State Historical Archives (Lviv) (F. 309, Op. 2, ed. 2274) ${ }^{59}$.

The mutual interest of the two peoples in the cultural life of each other was reflected in the Ukrainian and Belorussian periodicals of the early

\footnotetext{
${ }_{53}^{53}$ Шалата М. Два сонця білоруського письменства // Жовтень. - 1982. - № 11. - С. 98.

${ }^{54}$ Крип’якевич І. Білоруси. - Л.: Накладом т-ва “Просвіта”, 1909. - 16 с.

55 Щурат В. Шевченко - Желіговський - Чечот / Літературні начерки. - Л., 1913. - С. 94-99.

${ }^{56}$ Косич М. Литвины-белорусы Черніговской губернии: их быт и песни // Живая старина. - 1901. № 2. - С. 221-260; № 3-4. - С. 1-88.

57 Гнатюк В. [Рецензія]. М. Н. Косичь. Литвины-белорусы Черніговской губернии: их быт и песни // Записки Наукового товариства ім. Шевченка. - Л., 1903. - Т. 55. - Кн. 5. - С. $42-44$.

58 Яценко М. Володимир Гнатюк. - К., 1964. - С. 239-240.

${ }^{59}$ Там само. - C. 242.
} 
twentieth century. The constant interest in the Ukrainian theme was evidenced by "Nasha Nyva" - one of the first Belarusian-language weeklies $^{60}$. During the Shevchenko Anniversaries $(1911,1914)$, a number of literary-critical and non-fiction articles appeared in Belarusian writing that initiated pre-October Shevchenko studies in Belarus.

Therefore, a similar situation with education is also evident in the scientific relations between Ukrainians and Belarusians. In the beginning, the relations in this area were limited to those in the humanities. However, later relations in the scientific field began to take on the character of the interaction presented by the activity in Ukraine of Belarusians M. Bogdanovych, A. Pashkevych and others.

\section{CONCLUSIONS}

Despite the fact that the Belarusian-Ukrainian ties (educational and scientific) were rather "young", nevertheless, thanks to the relations of the two peoples, their cultures were enriched with new topics and images. In addition, the Ukrainian and Belarussian cultures have gained extensive experience in the interconnection process. A deep acquaintance with the spiritual achievements of neighboring peoples stimulated the development of one's own culture, showed what it lacked, kept it from repeating mistakes.

The stay of Belarusians in different educational establishments in Ukraine led to the establishment of personal contacts, which subsequently actively promoted scientific relations, dissemination of knowledge and culture in general.

Belarusian students participated in numerous unions and societies of diverse nature and orientation. In this regard, special attention deserves the creative activity on the territory of Ukraine of A. Pashkevych, M. DovnarZapolskyi, Ya. Zhurba, S. Poluyan, F. Bogushevych. Unlike their predecessors, who were interested in Ukraine and knew about it from the stories of eyewitnesses or from literary sources, these scientists and writers lived and worked for a long time among Ukrainians, knew their way of life, thoughts and aspirations.

Belarussian scientists were interested in the works of their Ukrainian colleagues and Ukrainians, in their turn, followed the achievements of researchers of Belarusian literature. Thus, M. Dovnar-Zapolskyi, Y. Karskyi, E. Romanov, and others wrote about Ukrainian writing, culture, and literature, and reviewed periodicals in various scientific publications, including articles pertaining to Ukraine. M. Drahomanov,

\footnotetext{
${ }^{60}$ Національна бібліотека України імені В. І. Вернадського. Інститут рукопису. - Ф. 274. - Оп. 1. Спр. 203.
} 
O. Potebnia, V. Hnatyuk, considering certain problems of history, philosophy, languages, always used Belarusian materials and introduced them to scientific use.

The bilateral cultural ties of the second half of the nineteenth and early twentieth centuries contributed to the revitalization of social and cultural life on the territory of the Belarussian and Ukrainian lands, the spread of innovative pedagogical thought, the development of scientific research, the setting up of publishing activities, etc.

\section{SUMMARY}

The article explores bilateral Belarusian-Ukrainian cultural, educational and scientific ties within the Russian and Austro-Hungarian monarchies. The basic tendencies of educational and cultural activity of individual persons, the role of their relations for national processes are analyzed. It is traced that pedagogical activity of Belarusians in educational establishments of Ukraine was an important area of educational relations, which explains the establishment of personal contacts. Contacts between scientists led to the expansion of research problems, contributed to the development of national science, especially the humanities. The place of Lviv as a cultural center in the history of the Belarusian-Ukrainian unity is explored.

The bibliographic data on a number of the personalities of Belarusian national-cultural movement were revealed, which made it possible to make significant clarifications to their biography.

\section{REFERENCES}

I. Державний архів Чернігівської області. - Ф. 140. - Оп. 1. Спр. 141. - 75 арк. 7 арк.

II. Державний архів міста Києва. - Ф. 16. - Оп. 164. - Спр. 2304. 57 арк.

III. Державний архів міста Києва. - Ф. 153. - Оп. 8. - Спр. 809. -

IV. Львівська національна наукова бібліотека України ім. В. Стефаника, відділ рукопису. - Ф. 82. - Оп. 1. - Спр. 24. - 14 арк.

V. Національна бібліотека України імені В.I. Вернадського. Інститут рукопису. - Ф. 8. - Оп. 1. - Спр. 3097. - 1 арк.

VI. Національна бібліотека України імені В.I. Вернадського. Інститут рукопису. - Ф. 10. - Оп. 4. - Спр. 17307. - 8 арк.

VII. Національна бібліотека України імені В.I. Вернадського. Інститут рукопису. - Ф. 274. - Оп. 1. - Спр. 203. - 10 арк. 
VIII. Центральний державний історичний архів України, м. Київ. - Ф. 262. - Оп. 1. - Спр. 159. - 5 арк.

IX. Центральний державний історичний архів України, м. Київ. Ф. 262. - Оп. 1. - Спр. 162. - 41 арк.

Х. Центральний державний історичний архів України, м. Київ. Ф. 262. - Оп. 1. - Спр. 165. - 3 арк.

1. Антошко М. Розвиток освіти на Поділлі кінця XIX - першої половини XX століття / Марина Антошко // Теоретичні питання культури, освіти та виховання : збірник наукових праць. - К. : Вид. центр КНЛУ, 2008. - Випуск 36. - С. 5-9.

2. Арабей Л. Цётка (Алаіза Пашкевіч) / Лидия Арабей. - Мн. : Мастацкая літаратура, 1956. - 126 с.

3. Богданович М. Стратим-Лебідь. Збірник творів: поезія, проза, публіцистика, критика, листи / [пер. 3 білорус. та рос. Романа Лубківський [та ін.]. - Л. : В-во Світ, 2002. - 406 с.

4. Богданович М. Угорська Русь / Максим Богданович. Скрентон: 3 друкарнї “Народної волї”, 1916. - 24 с.

5. Гнатюк В. [Рецензія]. М. Н. Косичь. Литвины-белорусы Черніговской губернии: их быт и песни / Володимир Гнатюк // Записки Наукового товариства ім. Шевченка. - Л., 1903. - Т. 55. Кн. 5. - С. 42-44.

6. Голубева Н. Беларусы Украины / Наталья Голубева // Беларускае замежжа. - Мн. : Медисонт, 2010. - С. 172-175.

7. Довнар-Запольский М.В. Очерк истории кривичской и дреговичской земель до конца XI столетия / Митрофан Викторович Довнар-Запольский. - К. : Б. в., 1891. - 170 с.

8. Довнар-Запольский М. В. Государственное хозяйство Великого княжества Литовского при Ягеллонах / Митрофан Викторович Довнар-Запольский. - К. : Б. в., 1901. - VIII, 807, CXII с.

9. Дробаў Л. Н. Беларускія мастакі XIX стагодзя / Леонид Никанорович Дробаў. - Мн. : Беларусь, 1971. - 109 с.

10. Дробов Л. Н. Живопись Белорусии XIX - начала XX веков / Леонид Никанорович Дробов. - Мн. : Высшая школа, 1974. - 334 с.

11. Епістолярна спадщина академіка Д. І. Яворницького. Листи вчених до Д. І. Яворницького. - Дніпропетровськ : Гамалія, 1998. Вип. 1. $-888 \mathrm{c.}$

12. Из истории школы Белорусии и Литвы / [под ред. Смирнова С. И.]. - М.: Просвещение, 1964. - 323 с.

13. Ильин А. Франтишек Богушевич и Конотопщина / Александр Ильин // Нёман. - 2000. - № 3. - С. 247-250. 
14. Извлечение из протоколов Конференции Института за 1883/84 учебный годь // Известия историко-филологического института князя Безбородка в Нежине 1883 - 1884. - М. - К., 1885. T. 9. - C. 126-129.

15.Исторические корни дружбы и единения белорусского и украинского народов / [под ред. Кондуфор Ю.Ю.]. - К. : Научная мысль, 1978. - 235 с.

16. Ільін А., Гарбачык М. Нацыянальнае адраджэньне пачатку XX ст. : беларуска-ўкраінскія повязі / Александр Ільін, Мыкола Гарбачык // Спадчына. - 2000. - № 2. - С. 37-57.

17. Журба Я. Лісты 3 Украйны II. Клапоты аб національнай школе / Янка Журба // Наша ніва. - 1909. - № 15. - С. 211-212.

18. Журба Я. Лісты з Украйны VII / Янка Журба // Наша ніва. 1909. - № 16. - С. 229-230.

19. Журба Я. Лісты з Украйны VIII / Янка Журба // Наша ніва. 1909. - № 33. - С. 480.

20. 3 нашага жыцьця // Наша ніва. - 1910. - № 36. - С. 547-548.

23. Карский А. Академик Карский. Страницы книги / Александр Карский // Нёман. - 2011. - № 8. - С. 152-153.

24. Кацер М. Изобразительное искусство Белорусии. Дооктябрский период / Михаил Кацер. - Мн. : Наука и техника, 1969. - 162 c.

25. Крип'якевич I. Білоруси / Іван Крип'якевич. - Л.: Накладом т-ва "Просвіта", 1909. - 16 с.

26. Косич М. Литвины-белорусы Черніговской губернии: их быт и песни / Марія Косич // Живая старина. - 1901. - № 2. - С. 221-260; № 3-4. - С. 1-88.

27. Купченко В. Архивные документы о гимназических годах М.В. Довнар-Запольского в фондах Государственного архива г. Киева / Віра Купченко // Чацвёртыя Міжнародныя Доўнараўскія чытанні: Рэчыца, 18-19 вересня 2003 р. у двох частках. - Гомель, 2004. - C. 22-27.

28. Купченко В. Маловідомі сторінки біографії М. В. ДовнарЗапольського / Віра Купченко // Ювілейна сесія до 140-річчя від дня народження М. В. Довнар-Запольського. [Збірник]. - Гомель, 2007. C. $17-34$.

29. Максім Багдановіч. Энцыклапедыя / [под. рэд. М.В. Труса]. Мн. : Беларус. Энцыкл. імя П. Броўкі, 2011. - 608 с.

30. Мараш Я. История Белоруссии эпохи феодализма в интерпретиции Ивана Франко / Яков Мараш // I. Франко і світова культура: матеріали міжнародного симпозіуму. - К.: Наукова думка, 1990. - Кн. 1. - C. 120-125. 
31. Народное образование и культура в БССР: Статистический сборник. - М. : Финансы и статистика, 1989. - 432 с.

32. Палуян С. Лісты з Украйны IX / Сергей Палуян // Наша ніва. 1909. - № 34. - С. 492-493.

33. Памятные книжки белорусских губерний [Электронный pecypc] / Национальная библиотека Беларуси. - Мн., 2012.

34. Перапіска М.В. Доўнар-Запольскага з дзеячамі навукі Украіны (1893-1908 гг.). - Гомель : Гомельск. дзярж. ун-т імя Ф. Скарыны, 2005. $-170 \mathrm{c}$.

35. Пігуляк М. Максим Богданович і Західна Україна / Микола Пігуляк // Радянське літературознавство. - 1964. - № 5. - С. 121-124.

36. Свєнціцький I. Відродження білоруського письменства / Іларіон Свєнціцький. - Л. : Наклад автора, 1908. - 62 с.

37. Скрыжалі памяці: 3 творчай спадчыны пісьменнікаў Беларусі, якія загінулі ў гады Другой сусветнай вайны. У 3 кн. Кн. 2 / [уклад., біягр. давед. пра аўт. і камент. А. Бельскага]. - Мн. : Бел. кнігазбор, 2005. $-656 \mathrm{c}$.

38. Czarnocki N. Wspomnienia (Nauczyciele Ukraińcy w Slucku) / N. Czarnocki // Biuletyn Polsko-Ukraiński: tygodnik ilustrowany. Warszawa, 1934. - № 6. - S. 2-3.

39. Ульяновський В. Двічі професор: Степан Голубєв в університетському та академічному контекстах / Василь Ульяновський. - К. : НКПІКЗ, “Фенікс”, 2007. - 360 с.

40. Шалата М. Два сонця білоруського письменства / Михайло Шалата // Жовтень. - 1982. - № 11. - С. 97-99.

42. Щурат В. Шевченко - Желіговський - Чечот / Василь Щурат / Літературні начерки. - Л. : Накладом авт.; 3 друк. Наук. Т-ва ім. Шевченка, 1913. - 105 с.

43. Яценко М. Володимир Гнатюк / Микола Яценко. - К. : Наукова думка, 1964. - 288 с.

44.250 асоб з Беларусі у дыялогах культур / [рэд.: Т. Л. Пісарэнка, Л.У. Языковіч]. - Мн. : Ін-т гісторыі, 2008. - 365 с.

\section{Information about the author: Hrytsenko H. Z.}

Candidate of Historical Sciences, Senior Lecturer at the Department of World History and Special Historical Disciplines,

Drohobych Ivan Franko State Pedagogical University 46, Lesya Ukrainka str., Drohobych, Lviv region, 82100, Ukraine 


\section{THE SOURCES TO THE HISTORY OF FUNCTIONING OF THE UKRAINIAN LIBERATION MOVEMENT IN THE CARPATHIAN REGION OF THE OUN (1945-1954) ${ }^{1}$}

\section{Ilnytskyi V. I.}

\section{INTRODUCTION}

The sources to the topic are characterized by the origin, storage, representativeness of historical facts, manning methods, degree of disclosure of certain aspects of the problem. The almost ten-year struggle of liberation movement in the Carpathian region of the OUN (Organization of Ukrainian Nationalists) has been reflected in a large number of different sources. We agree with Georgyi Papakin's opinion about the inappropriateness of "applying a scheme which provides a fundamental division into published and unpublished archival) sources [...] It is connected, first of all, with the peculiarities of historical sources of national liberation movement of the mid. XX th century, the necessity of the usage in their study all known classification features (origin, geography, authorship, publicity, circulation, storage, etc.). And just the publicity (the degree of actualization), the storage space does not play a significant role" ${ }^{2}$. In the process of the study of the OUN and URA (Ukrainian Rebel Army) struggle, a large number of sources were identified and divided into several main groups depending on their origin or authorship in the broad sense.

\section{The Documents of the OUN and URA}

The first, main, group is the OUN and URA documents. They are stored in central, sectoral, regional and private archives, museums, some are partially published. During the study, documents were mostly used. Because it was the PCIA-MIA and the PCSS-MSS-KGB that were fighting with the OUN and the URA, a considerable array of trophy - rebel documents were preserved in the Sectoral State Archives of the Security Service of Ukraine (SSA SSU). Most originals of clandestine documents (instructions, orders, reports, training programs for training, propaganda

\footnotetext{
${ }^{1}$ The article was published with the support of the Canadian Institute of Ukrainian Studies (with a grant from the Levko and Marika Babij Memorial Endowment Fund). Стаття побачила світ при підтримці Канадського інституту українських студій (з гранту Меморіяльного фонду ім. Левка і Марійки Бабіїв).

${ }^{2}$ Папакін Г. Українські визвольні змагання 1939-1956: джерельний контент. Вип. 1. Проблеми класифікації й змісту джерел повстанського та радянського походження / [відп. ред. Г. Боряк] / Інститут історії України НАН України. К., 2012. С. 105.
} 
literature) are stored in fund 13 ("The Collection of Printed Editions of the KGB of the USSR") of the State Security Service of Ukraine: case 376 (88 volumes), 398 (42 volumes) and, in part, case 372 (103 volumes). O. Ishchuk notes that the formation and staffing of these cases was carried out in the first half of the 1960s by order of the KGB head of the USSR Vitaliy Nikitchenko by the central office and the KGB in Volyn, Lviv, Ivano-Frankivsk, Rivne, Ternopil, Chernivtsi regions. The main organizing work was carried out by the Deputy Head of the Department of the 4th KGB Department of the USSR, Lieutenant Colonel Mykola Makhov. Sometimes, documents, even in single copies, were removed from the KGB regional offices without making copies. It is important to note that the documents of this fund are not systematized even by territorial and chronological principle. The mentioned cases contain instructions, orders, reports, correspondence, training programs, propaganda literature (brochures, leaflets, newspapers, appeals), and there are many underground reports. Of special importance for the study of propaganda activities is the collection of printed editions of OUN structures. Some of the documents are translated into Russian.

Both originals and translations into Russian are rather important and stored in the 2nd fund (Department of Combating Banditry of the Ministry of Internal Affairs, Office 2-N and 4th Department of the MSS-KGB of the USSR). It should be mentioned the diary notes of Peter Fedun-"Poltava" describing the situation in the Carpathian region in mid $-1949^{3}$ and the characteristics of the Carpathian region, compiled by Vasyl Sidor"Shelest". The rebel documents are also stored in f. 65 SSA SSA.

A large body of underground documentation, mainly for the years 1944 - 1946, concerning the problems of the functioning of the Ukrainian liberation movement in the Carpathian region of the OUN, is stored in the Central State Archives of Higher Authorities and Administration of Ukraine (CSAHA of Ukraine $)^{5}$. First of all, in the materials of the funds: 3833 "Crayovyi Provid" of the Organization of Ukrainian Nationalists in Western Ukraine in 1941-1947"; 3836 "The Union of Western Groups of the Ukrainian Rebel Army URA-Zahid". We should note the input and output documentation of the OUN Drohobych propaganda unit for May 1945 - January 1946, especially the district and supra-district level reports and instructions on the structure of the referral ${ }^{6}$.

${ }^{3}$ ГДА СБУ. Ф. 13. Спр. 398. Т. 13. Арк. 150-153.

${ }^{4}$ ГДА СБУ. Ф. 2-Н. Оп. 59 (1953). Спр. 6. Т. 4. Арк. 152-175; Ф. 13. Спр. 372. Т. 9. Арк. 16-59.

${ }^{5}$ ЦДАВО України. Ф. 3833. Оп. 1. Спр. 226. Арк. 123; Ф. 3836. Оп. 1. Спр. 67. Арк. 12, 34, 43-44, 46, 58, 68, 69, 111, 129, 184-184зв., 189, 196, 243, 259, 306; Спр. 70. Арк. 2; Ф. 3838. Оп. 1. Спр. 4а. Арк. 28, 29, 30-32.

${ }^{6}$ ЦДАВО України. Ф. 3836. Оп. 1. Спр. 67: пропагандистські матеріали референта пропаганди округа "Маківка" - “Тустань" - “Аркадія". 381 арк. 
A large number of underground documents (in originals, and partly in Russian copies) are stored in the Central State Archive of Public Associations of Ukraine (CSAPA of Ukraine). There is no separate fund in which all OUN and URA documents would be collected, but the main file is stored in the fund "The Central Committee of the Communist Party of Ukraine" (F. 1. - Op. 23), which contains mostly propaganda materials in copies. The rest of the materials is scattered in various cases of this and other funds (mostly copies).

OUN and URA documents as evidences are contained in archival criminal cases, in particular in funds 5 and 6 of the Branch State Archives of the Security Service of Ukraine and the regional offices of the Security Service of Ivano-Frankivsk, Transcarpathia, Lviv and Chernivtsi regions.

The part of the underground documents were kept in the state archives of the Transcarpathia, Ivano-Frankivsk, Lviv, Chernivtsi regions, as well as in the funds of regional committees of the Communist Party (Bolsheviks) of Ukraine $(\mathrm{CP}(\mathrm{b}) \mathrm{U})$ of Transcarpathia (f. P-1), IvanoFrankivsk (f. P-1), Lviv (P-5001), Chernivtsi (f. P-1) regions.

It is worth noting a certain feature of the State Archives of Lviv region (SALR), which contains a large array of individual cases of struggle of the authorities with the liberation movement, underground documents, special instructions. Apparently, under the pressure of the public and the reluctance of the archives to execute a criminal order, these documents are preserved. The large P-5001 fund - Drohobych Regional Committee of the Communist Party (Bolsheviks) of Ukraine $(\mathrm{CP}(\mathrm{b}) \mathrm{U})$ - is well preserved, with a number of underground documents found, most of them in copies and translations (orders, instructions, reports).

In the archive of the Center of the Study of the Liberation Movement, a significant source base was collected, based on the documents of the OUN and URA. A unique collection of documents is the so-called "Lebid's archive", formed on the basis of underground materials that were in emigration. A large array of OUN and URA documents found during Ukraine's independence is also in this archive of the institution.

The small P-9 fund contains only one description (16 cases) with educational and propaganda materials stored in the Central State Historical Archives of Ukraine in Lviv.

The array of propaganda literature was accumulated in fund 262 "The Organization of Ukrainian Nationalists and the Ukrainian Rebel Army" of the manuscripts department of the Lviv V. Stefanyk Scientific Library of the NAS of Ukraine. Thus, a large set of documents directly related to the functioning of the Ukrainian liberation movement in the OUN Carpathian region was kept in the home archive of Hryhoriy Demian, 
which was deposited to fund 262. It should be noted also the value of documents from the private archive of Zinovyi Boychuk.

It is also necessary to separate the documents of private archives, ascertain the presence of a whole layer of underground documents (mainly propaganda and reporting, sometimes instructive) and, importantly, photo illustrations accumulated in museums at different levels (regional, district, city, rural) of Transcarpathia, Ivano-Frankivsk, Lviv, Chernivtsi regions.

The searchers continue to find underground archives. For example, in 2002 in the village Tysiv Ivano-Frankivsk region they found an underground archive that was contained in two cans and consisted mostly of propaganda literature, leaflets, brochures, orders among them. In 2014, several cans of materials from the archives of the Sambir sub-district OUN provid were found in the Staryi Sambir region (in the neutral lane of the Ukrainian-Polish border), a large part of which is the materials of the Security System of of Nyzhnyi Ustryts OUN regional provid (1945-1947) and Strilky regional provid OUN. We consider it especially effective the founding of 2015, when was managed to find a collection of underground documents in the village Pistyn' of Kosiv district, as well as the archive of the OUN Kalush district provid.

The greater part of OUN and URA documents is published. The first such publications began to be published in OUN's foreign parts in the series "The Library of the Ukrainian Underground" (16 books), started in the 1950s. The mentioned collections contained leaflets and articles from underground members, and various programmatic and propaganda materials ${ }^{7}$.

A considerable array of the documents has been published in the fundamental documentary "The Chronicle of the Ukrainian Rebel Army". Today, two editions are published - the main one in 1975 in Canada (53 volumes were published till 2018) and the new one, which has been in print since 1995 in Kiev (28 volumes till 2018). Today, the URA Chronicle is the largest array of printed sources in the history of the Ukrainian liberation movement, joined in one edition. The main series of "The Chronicles of the URA" contain underground reports, official documents, as well as articles, memoirs and publications of historical and

\footnotetext{
${ }^{7}$ ОУН в світлі постанов Великих Зборів, Конференцій та інших документів з боротьби 1929-1955. [Б.м.]: Видання Закордонних частин ОУН, 1955. 372 с. (“Бібліотека українського підпільника” Ч. 1); УПА в світлі документів 3 боротьби за Українську Самостійну Соборну Державу 1942-1950 pp. [Б.м.]: Видання Закордонних частин ОУН, 1957. Ч. 1. 452 с. (Серія "Бібліотека українського підпільника" Ч. 6); УПА в світлі документів з боротьби за Українську Самостійну Соборну Державу 1942-1950 pр. Бойові дії УПА за 1943-1950 рр. [Б.м.]: Видання Закордонних частин ОУН, 1960. Ч. 2. 444 с. (Серія “Бібліотека українського підпільника" Ч. 7); УГВР в світлі постанов Великого Збору та інших документів 3 діяльности 1944-1951 pр. [Б.м.]: Видання Закордонних частин ОУН, 1956. 356 с. (Серія "Бібліотека українського підпільника" Ч. 3); АБН в світлі постанов Конференцій та інших матеріялів 3 діяльности 1941-1956 рр. [Б. м.]: Вид. ЗЧ ОУН, 1956. 368 с.
} 
memoir nature that are stored abroad. Of particular importance are the reports of individual administrative structures of the Ukrainian underground. In the context of the study of the topic identified, volumes 3, 4 "Chornyi Lis" ("The Black Forest") and 18, 19, entitled "Group URA "Hoverlia"8 are important. These volumes include reports and publications containing information on OUN and URA activities in the OUN Carpathian region. In the work the volumes devoted to the creation and activity of the Ukrainian General Liberation Council (UGLC) ${ }^{9}$, medical service ${ }^{10}$, construction and operation of hoods (bunkers) ${ }^{11}$ were used directly.

Unlike the main one, the new series of "The URA Chronicle" was printed in Ukraine is based on the documents of archival institutions of Ukraine. Among them are the collections of documents and materials of Bukovyna (compiled by Dmytro Prodanyk), Stanislav (compiled by D. Prodanyk ${ }^{12}$ and S. Lesiv) ${ }^{13}$ and Kolomyia district (compiled by D. Prodanyk, V. Humeniuk) $)^{14}$.

The specialist archeographic work is performed by Volodymir Serhiychuk for a long time. His compilations contain a large array of

8 Літопис Української Повстанської Армії. Т. 3: Чорний ліс: видання команди Станиславівського тактичного відтинка УПА 1947-1948 роки. Передрук підпільного журналу УПА (1947-1948) / [відп. ред. Є. Штендера, співред. П. Потічний]. Торонто: Літопис УПА, 1978. Кн. 1. 272 с.; Літопис Української Повстанської Армії. Т. 4: Чорний ліс: видання команди Станиславівського тактичного відтинка УПА 1947-1950 роки. (1948-1950) / [відп. ред. Є. Штендера, співред. П. Потічний]. Торонто: Літопис УПА, 1979. Кн. 2. 288 с.; Літопис Української Повстанської Армії. Т. 18: Група УПА “Говерля". Документи, звіти та офіційні публікації / [упоряд. Петро Содоль]. Торонто: Літопис УПА, 1990. Кн. 1. 328 с.; Літопис Української Повстанської Армії. Т. 19: Група УПА “Говерля". Спомини, статті та видання історично-мемуарного характеру / [упоряд. Петро Содоль]. Торонто; Львів: Літопис УПА, 1992. Кн. 2. 360 с.

9 Літопис Української Повстанської Армії. Т. 8: Українська Головна Визвольна Рада; документи, офіційні публікації, матеріали / [ред.-кол. Свген Штендера, Петро Потічний]. - Торонто: Літопис УПА, 1980. Кн. 1: 1944-1945. 320 с.; Літопис Української Повстанської Армії. Т. 9: Українська Головна Визвольна Рада. Документи, офіційні публікації, матеріяли / [ред.-кол. Свген Штендера, Петро Потічний]. Торонто: Літопис УПА, 1982. Кн. 2: 1946-1948. 520 с.; Літопис Української Повстанської Армії. Т. 10: Українська Головна Визвольна Рада. Документи, офіційні публікації, матеріяли / [ред.-кол. Свген Штендера, Петро Потічний]. Торонто: Літопис УПА, 1984. Кн. 3: 1949-1952. 424 с.; Літопис Української Повстанської Армії. Т. 24: Ідея і чин: Орган Проводу ОУН, 1942-1946 / [ред.кол. Юрій Маївський, Свген Штендера]. Торонто; Львів: Літопис УПА, 1996. 342 с.; Літопис Української Повстанської Армії. Т. 26: Українська Головна Визвольна Рада / [ред. Петро Потічний]. Торонто; Львів: Літопис УПА, 2001. Кн. 4: Документи і спогади. 658 с.

10 Літопис Української Повстанської Армії. Т. 23: Медична опіка в УПА [упоряд. Петро Содоль]. Торонто; Львів: Літопис УПА, 1992. 480 с.; Літопис Української Повстанської Армії. Т. 32: Медична опіка в УПА: документи, матеріяли і спогади / [ред. Модест Ріпецький]. Торонто; Львів: Літопис УПА, 2001. Кн. 2. 581 с.

${ }^{11}$ Літопис Української Повстанської Армії. Т. 38: Архітектура резистансу: криївки і бункери УПА в світлі радянських документів / [ред. Петро Потічний]. Торонто; Львів: Літопис УПА, 2002. 430 с.

12 Літопис Української Повстанської Армії. Нова серія. Т. 19: Підпілля ОУН на Буковині: Документи і матеріали. 1943-1951 / [упоряд. Дмитро Проданик]. К.; Торонто: Літопис УПА, 2012.840 с.

13 Літопис Української Повстанської Армії. Нова серія. Т. 22: Станиславівська округа ОУН: документи і матеріали 1945-1951 / [упоряд. Дмитро Проданик, Степан Лесів]. К.; Торонто: Літопис УПА, 2013. $1376 \mathrm{c}$.

14 Літопис Української Повстанської Армії. Нова серія. Т. 25: Коломийська округа ОУН: документи і матеріали 1945-1952 / [упоряд. Дмитро Проданик, Василь Гуменюк]. К.; Торонто: Літопис УПА, 2015. 1104 с. 
underground documents ${ }^{15}$. Some underground materials - program documents, orders, instructions, reports on the work done, appeals to the population - were published in the collection "Ukrainian National Liberation Movement in the Carpathian region in the XX century"16. Volodymyr Moroz published several important letters to the leaders of the nationalist movement concerning the creation of the Carpathian region ${ }^{17}$.

In the context of the study the official ethno-national policy of nationalists in the relation to representatives of other nationalities, the collection compiled by V. Panibudlaska matters ${ }^{18}$.

The collections of documents and materials on the Ukrainian-Polish confrontation are also very important that have been published over the last few years and edited by Volodymyr Viatrovych. The book includes littleknown documents that, in addition to a value of factual material about the persecution, make it possible to take a fresh approach to the study of the problems of the Polish-Ukrainian conflict ${ }^{19}$. The work of Vasyl Ilnytskyi and Mykola Haliv is dedicated to the activities of the Security Service in Drohobych region $^{20}$.

15 Сергійчук В. ОУН-УПА в роки війни. Нові документи і матеріали. К.: Дніпро, 1996. 496 с.; Сергійчук В. Сергійчук В. Десять буремних літ. Західноукраїнські землі у 1944-1953 рр. Нові документи і матеріали. К.: Дніпро, 1998. 944 с.; Сергійчук В. Український здвиг: Волинь. 1939-1955 рр. К.: Українська Видавнича Спілка, 2005. 840 с.; Сергійчук В. Український здвиг: Закерзоння. 1939-1947 рр. К.: Українська Видавнича Спілка, 2004. 836 с.; Сергійчук В. Український здвиг: Наддніпрянщина. 1941-1955 pр. К.: Українська Видавнича Спілка, 2005. 836 с.; Сергійчук В. Український здвиг: Поділля. 1939-1955 pр. К.: Українська Видавнича Спілка, 2005. 840 с.; Сергійчук В. Український здвиг: Прикарпаття. 1939-1955 рр. К.: Українська Видавнича Спілка, 2005. 840 с.; Роман Шухевич у документах радянських органів державної безпеки (1940-1950). К.: ПП Сергійчук М. І., 2007. Т. 1. 640 с.; Роман Шухевич у документах радянських органів державної безпеки (1940-1950). К.: ПП Сергійчук M. I., 2007. T. 2. 584 c.

16 Український національно-визвольний рух на Прикарпатті в XX столітті. Документи i матеріали / [відп. ред. проф. Микола Кугутяк]. Т. 2. Івано-Франківськ: КПФ “ЛІК”, 2009. Кн. 1: 1939-1945. 600 с.; Український національно-визвольний рух на Прикарпатті в ХХ столітті. Документи і матеріали / [відп. ред. проф. Микола Кугутяк]. Т. 2. Івано-Франківськ: КПФ “ЛІК”, 2010. Кн. 2: 1945-1946. 696 с.; Український національно-визвольний рух на Прикарпатті в ХХ столітті. Документи і матеріали / [відп. ред. проф. Микола Кугутяк]. Т. 2. Івано-Франківськ: КПФ “ЛІК”, 2011. Кн. 3 : 1947-1957. $768 \mathrm{c}$.

17 Мороз В. 3 листування членів Проводу ОУН (листопад 1944 - травень 1945) // Украӥнський визвольний рух. Львів, 2007. Збірник 10: До 100-річчя від дня народження Романа Шухевича. С. 34-52.

${ }^{18}$ Національні процеси в Україні: історія і сучасність. Документи і матеріали. Довідник: В 2 ч. / [упоряд. І. О. Кресіна (керівник), О.В.Кресів, В. П. Ляхоцький, В. П. Панібудьласка]. К.: Вища школа, 1997. Ч. 1. 583 с.; Національні процеси в Україні: історія і сучасність. Документи і матеріали. Довідник: В 2 ч. / [упоряд. І. О. Кресіна (керівник), О. В. Кресів, В. П. Ляхоцький, В. П. Панібудьласка]. К.: Вища школа, 1997. Ч. 2. 704 с.

19 Польсько-українські стосунки в 1942-1947 роках у документах ОУН та УПА: у 2 т./ [відп. ред. та упоряд. В. В’ятрович]. Львів: Центр досліджень визвольного руху, 2011. Т. 1: Війна під час війни (1942-1945). 792 с.; Польсько-українські стосунки в 1942-1947 роках у документах ОУН та УПА: у 2 т. / [відп. ред. та упоряд. В. В’ятрович]. Львів: Центр досліджень визвольного руху, 2011. Т. 2: Війна після війни (1945-1947). 576 с.

20 Діяльність Служби безпеки ОУН на Дрогобиччині: документи і матеріали (1944-1951) / [упоряд. Василь Ільницький, Микола Галів; передмова - Василь Ільницький, примітки - Микола Галів]. Кн. 1. Дрогобич: Швидкодрук, 2009. 264 с. 


\section{The documents of the repressive and punitive bodies of the USSR}

The second group of sources consists of documents of the repressivepunitive bodies of the USSR, which reflect the struggle of the special services against the structures of the OUN and URA, as well as the activities of nationalists against the approval of the authorities. Most of these documents, despite repeated large-scale destruction, are stored in the Sectoral State Archives of the Security Service of Ukraine. According to researchers and archivists, the Sectoral State Archives of the Security Service of Ukraine and its regional offices have "survived" at least three major "cleanups". The beginning was ordered (№ 00511, 1954) by the KGB head of the USSR, whose essence consisted in the necessity, during 1954-1955, to clear operational archives of "compromising" materials on "honest Soviet citizens, obtained through falsification and use of illegal methods of evidences". In fact, due to this order the documents that contained information about the extent of the repressive policy of the authorities against the national liberation movement were destroyed. Repeated "revision and ordering", as well as the destruction took place at the regular instruction of the center in 1960-1962. The last destruction was by the same order (№ 00150, 1990) of the KGB of the USSR. This time, archival materials that "do not represent operational value" were subject to destruction.

By the decree of the President of Ukraine of January 23, 2009, it was ordered the authorities to declassify archival documents related to the Ukrainian liberation movement, political repressions and famines in Ukraine. As a result, a number of archival funds were opened to the general public, shedding light on the struggle of the Soviet special services against the liberation movement, and scientists were given access to the documents of the fund 2 of the SSA SSU (fundraisers - control of the Banditry of the PCSS of the USSR in 1943-1946., department 2-N MSS of the USSR in 1947-1953 and the 4th KGB department of the USSR in 1953-1960). The bulk of the materials of the 2-N foundation are the documents of the Soviet state security bodies - reports, daily reports, search materials, orders, correspondence, agent reports ${ }^{21}$. The similar review documents of the Soviet punitive bodies are also contained in the

${ }^{21}$ ГДА СБУ. Ф. 2-Н. Оп. 54 (1953). Спр. 3. Т. 1. Арк. 260; Оп. 55 (1953). Спр. 5. Т. 1. Арк. 123-124, 190, 266, 347; Оп. 59 (1953). Спр. 7. Т. 2. Арк. 147-148; Оп. 60 (1953). Спр. 3. Т. 5. Арк. 186, 195-196; Оп. 67 (1953). Спр. 11. Арк. 33; Оп. 93 (1954). Спр. 1. Арк. 35, 47, 189, 238, 365, 377; Спр. 2. Арк. 35, 36; Оп. 98 (1954). Спр. 1. Т. 2. Арк. 47; Оп. 110 (1954). Спр. 2. Т. 5. Арк. 8, 24, 146-153, 154, 264-266, 269, 270; Т. 6. Арк. 214, 215; Т. 7. Арк. 8, 215-216, 221-225, 250; Т. 8. Арк. 243-244, 378; Оп. 28 (1960). Спр. 16. Арк. 136-138, 247; Т. 17. Арк. 14-15; Т. 20. Арк. 95-96, 98-99; Ф. 65. Спр. 7443. Арк. 232, 233, 267; Спр. 9079. Т. 52. Арк. 217-219; Ф. 71. Оп. 6. Спр. 203. Арк. 205; ЦДАГО України. Ф. 1. Оп. 23. Спр. 2968. Арк. 6-8. 
volumes of the already mentioned 372nd case of the 13th fund (extracts from reports, operative-search materials, orders, correspondence) ${ }^{22}$.

The most valuable are those documents of fund 2, which store daily records on the fight against underground in Ivano-Frankivsk, Transcarpathia, Drohobych, Chernivtsi regions, special messages, memos, notes. These reports were made by district and regional departments of 2-N immediately after the operation and contain detailed data of time, place, names of divisions, their heads, biographical data about the dead. The desire to report as soon as possible about the successful operation led to mistakes and inaccurate identification of the dead. In the fund, "Verkhovyntsi" multi-volume agency case (№ 304), instituted in December 1945 by the participants of the Carpathian Regional Leadership of the OUN, is of great importance. The case was implemented by the department of PCSS-MSS of Stanislav region, where it was stored until 1990, but due to the above-mentioned purges by the order of the KGB of the USSR (№ 00150 of 1990) it was completely destroyed. But in fund 2 of the SSA SSU a supervisory case on the work of the department of the Security Service of Ivano-Frankivsk region is remained. ${ }^{23}$ It contains documentation of UMSS of the Ivano-Frankivsk region of the MSS USSR for 1945-1954 the excerpts from investigative cases on the heads of the underground of the Carpathian regional provid, Kalush, Kolomyia, Stanislaviv district of OUN wires, instructions, orders, and a considerable array of important documents. In general, these documents reveal the stages and principles of organizing the liquidation of the governing structures of the underground of the Carpathian region.

The materials of the KGB department of Lviv region (f. 71), which contain documents from that part of the Carpathian region, are important.

The part of the documents of the punitive and repressive bodies of the USSR contains the analysis of the activities of the underground and measures to combat it. They make it possible today to reveal the mechanisms of real activity of the punitive bodies. It is also necessary to mention the documents f. 1 (2nd department of the MSS-KGB of the USSR), f. 3 (5th department of the MSS-KGB of the USSR) and f. 16 (the Secretariat of the SPU-KGB of the USSR). They contain supervisory cases on the fight against foreign intelligence agents, operational reporting by area (f. 1), various correspondence, control and surveillance cases on terrorist acts, briefing notes on agency and operative work (f. 3-5 department of the MSS-KGB of the USSR), copies of the summary

${ }^{22}$ ГДА СБУ. Ф. 13. Спр. 372. Т. 1. Арк. 227; Т. 2. Арк. 5-7; Т. 4. Арк. 245; Т. 5. Арк. 165-167; Т. 6. Арк. 38, 78; Т. 16. Арк. 273-275; Т. 18. Арк. 157-158; Т. 23. Арк. 400-422; Т. 26. Арк. 166-167; Т. 53. Арк. 232; Т. 56. Арк. 9-14, 131, 133, 169-170, 431-432; Т. 77. Арк. 131, 133, 371-376.

${ }^{23}$ ГДА СБУ. Ф. 2-Н. Оп. 110 (1954). Спр. 2. 
special messages, memos and submissions, the results of the fight against the OUN underground (f. 16).

The importance of the study of the functioning of the Ukrainian liberation movement in the Carpathian region of the OUN (1945 - 1954) contains f. 65 (cases of operational accounting of the KGB of the USSR), which contains the investigation and search cases on Petro Fedun ${ }^{24}$, Vasyl Sydor $^{25}$, Roman Tuchak ${ }^{26}$, as well as on the agent development of the Drohobych district of the OUN "Berloga"27. The materials of fund 65 are extremely important for the reconstruction of the circumstances of the death of the underground, as well as give an opportunity to highlight the methods and forms of work of special services. Among other things, it also contains the so-called case files for individual heads of the underground, to their cases agent data, extracts from underground documents and letters, excerpts from interrogation records, which mentioned the name of the person involved in the case and plans for his search and liquidation were primarily included.

The important information required for the reconstruction of the personnel of the region and district divisions of the PCHA-MHA and the PCSS-MSS, their quantitative and qualitative characteristics is contained in the personnel department of the KGB of the USSR (f. 8). The documents that reflect the functioning of the penitentiary system at the republican and regional levels (f. 20 - the KGB detention center of the USSR) are valuable. However, most cases with directives of prison departments of the PCHA of the USSR and the PCSS of the USSR to the heads of prison departments of the regional departments of the PCHA, correspondence of organs, memos, internal arrangements of prisons in the regions were destroyed.

The documents in the archives of the SSU departments of the Transcarpathia, Ivano-Frankivsk, Chernivtsi regions, which should have kept the materials of the PCSS-MSS with underground, were destroyed in the late 1980s and early 1990s. A somewhat different situation with the archival department of the SSU of Lviv region, in which materials from the PCSS-MSS-KGB of the Drohobych region were stored, was deposited in the SSA SSU in the late 1980s. Already there, some of the cases were destroyed. These are, first of all, the materials of all the regional divisions of the PCSS-MSS-KGB for the years 1939-1980, as well as the cases of

\footnotetext{
${ }^{24}$ ГДА СБУ. Ф. 65. Спр. 9112. Т. 17.

${ }^{25}$ ГДА СБУ. Ф. 65. Спр. 7443.

${ }^{26}$ ГДА СБУ. Ф. 65. Спр. 8707. Т. 1.

${ }^{27}$ ГДА СБУ. Ф. 65. Спр. С-9159; Спр. С-9186. Т. 1-2.
} 
the so-called activity of special groups ${ }^{28}$. Now the documents of the KGB directorate of Lviv region have been merged into 71 .

The documents of the punitive bodies contain considerable inaccuracies, during their drafting they were first guided by the desire to identify and prove the guilt of a person, to show the so-called "criminal" nature of their activity, and not to present the national liberation movement objectively. It should be emphasized that the criminal authorities reported what they knew what was needed first and foremost to eliminate the underground.

Obviously, the documents and materials of the Archival Directorates of the Ministry of Internal Affairs in the Transcarpathia, Ivano-Frankivsk, Lviv, Chernivtsi regions, in which thousands of cases of persons who were evicted to "remote areas of the USSR" can be found, are of great scientific and cognitive importance. Today, however, the funds of this archive remain to be classified as secret and are not accessible to researchers.

Archival-criminal cases (ACC), which make it possible not only to fill in the gaps in the structure of personal siege (fullness), but also to write in these biographies in the context of national liberation struggle simultaneously, to trace the forms and methods of combating the repressive and punitive system. When dealing with interrogation protocols, one should remember that this is a subjective source of information. It should be understood that the investigator tried to justify the accusations (confessions of the arrested was often enough to be justified), arrested - to hide as much as possible about himself, his activities and relatives, thereby protecting them from repression. In addition, all this happened under moral, psychological and physical constraints, which could only be resisted by one. In later years, the investigation was much more thoroughly conducted with the respect to the nationalists of the leading persons, the physical torture took a secondary or even a last place, instead a broader evidence base was gathered.

In SSA SSU in the Transcarpathia, Ivano-Frankivsk, Lviv and Chernivtsi regions, tens of thousands of archival criminal cases of convicted participants of liberation competitions have been accumulated. Of particular interest are the cases concerning the management of regional, district and sub-district provids, since their representatives were informed more than ordinary undergrounds. The cases of $\mathrm{f}$. 5 (criminal cases against non-rehabilitated persons) and f. 6 (criminal cases against rehabilitated persons) of SSA SSU, cases of the Department of Security System of Ukraine in Ivano Frankivsk region (DSSUIFR), the Department of Security System of Ukraine in Transcarpathia region (DSSUTR), the Department of

${ }^{28}$ ГДА СБУ. Ф. 71. Опис фонду. 
Security System of Ukraine in Lviv region (DSSULR), the Department of Security System of Ukraine in Chernivtsi region (DSSUCR).

It should also be noted that a number of persons, despite reliable information about their arrest, failed to identify criminal cases. Obviously, it did not start because the person went for open cooperation with punitive bodies or the case itself was destroyed or transferred to other institutions (for example, the Russian Federation).

Some separate interrogation protocols are contained in a number of volumes of the mentioned 372th case of fund 13. The further information on the undergrounds of Drohobych district is contained in interrogation protocols published in the ninth (Yaroslav-Dmitro Vitovskyi, Myroslav Haiduk, Artemizia Halytska, Oleksandr Lutskyi) and in the fifteenth (Julian Matviyiv, Mykola Krychun) volumes of the new series of "the URA Chronicles"29.

It is worth noting that, despite a number of inaccuracies, the interrogation protocols and other materials of criminal cases contain extremely valuable biographical information, the information about the structure and management.

Although according to the degree of authenticity of the information, the interrogation protocols are close to the memoirs, but they have not lost their value, because the information is recorded in "fresh footprints". However, it is marked by subjectivity, as it is usually received from an underground using physical torture, psychological pressure. In addition, the terminology in interrogation protocols and the use of the statements of an arrested person should be carefully considered. For example, all members of the national liberation movement were called "bandits", units of the URA were called "gangs", and supporters were called "band aides". Analyzing archival criminal cases, it was possible to find a large-scale calculation of the convictions. Despite the rejection of ideological stamps and layers, interrogation protocols after careful critical analysis can be considered as an important source for studying the history of the liberation struggle in the Carpathian region of the OUN.

A significant addition to the set of sources is the accounting records of fund 111 ("The Collection of Accounting and Personal Cases for Rehabilitated Special Settlers") of the Archival Sector of the Main Directorate of the National Police in Lviv region for families of

${ }^{29}$ Літопис Української Повстанської Армії. Нова серія. Т. 9: Боротьба проти повстанського руху і націоналістичного підпілля: протоколи допитів заарештованих радянськими органами державної безпеки керівників ОУН і УПА / [упоряд. Олександр Іщук, Сергій Кокін]. 1944-1945. К.; Торонто: Літопис УПА, 2007. 912 с.; Літопис Української Повстанської Армії. Нова серія. Т. 15: Боротьба проти повстанського руху і націоналістичного піпілля: протоколи допитів заарештованих радянськими органами державної безпеки керівників ОУН і УПА. 1945-1954 / [упоряд. С. Власенко, С. Кокін, В. Лозицький]. К.; Торонто: Літопис УПА, 2011. Кн. 2. 840 с. 
undergrounds and rebels who were deported to remote regions of the USSR, as well as on "expats" and "special settlers". The involvement of this category of cases, in particular the use of the indictments cited by them, gives grounds for claiming the use of hostages in the underground, gross falsification of cases and groundless mass repression. At the same time, the researcher's appeal to the materials of this fund is important informative for determining the time, place and circumstances of the death of certain undergrounds, the fate of their families, the output of statistics on the repression of the occupying power against the civilian population and the specifics of conducting deportation actions. The fund itself is not properly organized - several cases are stored under the same number, which can only be identified by name, although it would be more appropriate to divide cases into volumes.

The archives of Transcarpathia, Ivano-Frankivsk, Lviv, Chernivtsi regional offices of the search and publishing agency "The Memory Book of Ukraine", which stores files of thousands of people, based on processed data of archival-criminal cases, memoirs of participants and eyewitnesses to those events, which is certainly a great help in identifying nationalists, especially minor ones, are valuable for studying the staff of underground and underground structures.

The greater part of the punitive and repressive documents were published. One of the first was the collection, organized by Ivan Bilas, which contains documents on the activities of the repressive and punitive bodies to combat the underground of the Carpathian region of the $\mathrm{OUN}^{30}$. A number of materials of repressive and punitive bodies have been published in the already mentioned works of Volodymyr Serhiychuk. His subsequent works are also filled with the information that makes it possible to draw a holistic picture of the authorities' struggle against the underground ${ }^{31}$. To study the deportation policy of the Soviet administration, the three-volume document, generally edited by Yuri Slyvka, entitled "The Deportations: Western Lands of Ukraine in the late 1930s and early 1950s. Documents, Materials, Memories" is of particular value for the research ${ }^{32}$.

\footnotetext{
${ }^{30}$ Білас І. Репресивно-каральна система в Україні 1917-1953. Суспільно-політичний та історичний аналіз. У двох книгах. К.: Либідь; Військо України, 1994. Книга друга: Документи та матеріали. 688 с.

${ }^{31}$ Сергійчук В. Депортація поляків з України. Невідомі документи про насильницьке переселення більшовицькою владою польського населення з УРСР в Польщу в 1944-1946 роках. К.: Українська видавнича спілка, 1999. 191 с.; Сергійчук В. Самі себе звоювали. Діяльність винищувальних батальйонів проти українського національно-визвольного руху. К.: Українська видавнича спілка. 80 с.; Сергійчук В. Тавруючи визвольний прапор. Діяльність агентури та спецбоївок НКВС-НКДБ під виглядом ОУН-УПА. Видання друге, доповнене. К.: ПП Сергійчук М.I., 2006. 184 с.

32 Депортації: Західні землі України кінця 30-х-початку 50-х рр. Документи, матеріали, спогади. У трьох томах / [упоряд. Юрій Сливка]. Львів: Інститут українознавства імені Івана Крип’якевича НАН України, 1996. Т. 1: 1939-1945 pp. 750 с.; Депортації: Західні землі України кінця 30-х - початку 50-х рр. Документи, матеріали, спогади. У трьох томах. / [упоряд. Юрій Сливка]. Львів: Інститут українознавства імені Івана Крип’якевича НАН України, 1998. Т. 2: 1946-1947 pp. 540 с.
} 
One of the important sources is the documentary, which was published in the 1970s, and dedicated to the activities of border troops, which were entrusted not only with direct functions of state border protection, but also that often occurred at the initial stage of confrontation, struggle with the Ukrainian liberation movement. Since the Carpathian region covered the regions of the USSR, which bordered on a number of countries, much more forces were concentrated on its territory than on the territory of other regions ${ }^{33}$.

The collection of documents on the liberation struggle of 1944-1948 in the western regions of Ukraine is considered to be a significant supplement to the documentary base about the repressive activity of Soviet administration, which includes the collection of materials from so called "Special folders" of Joseph Stalin and Vyacheslav Molotov from the State Archives of the Russian Federation ${ }^{34}$.

The collections of documents published in Soviet times, contain tendered information, and therefore require a critical approach ${ }^{35}$. Since Ukraine's independence, they have been periodically appearing to exacerbate opposition in society ${ }^{36}$. Some materials in the history of the national liberation movement of the Carpathian region were selected for discrediting purpose. This include, published apparently for ideological war, a two-volume documentary, "The Ukrainian Nationalist Organizations in the Second World War," which contains 506 documents from 15 archives of Russia, Ukraine, Germany, Poland, Belarus ${ }^{37}$.

The article by Igor Marchuk ${ }^{38}$ is also of source importance, which provides an overview of the complex of documents of colonel Serhyi Stekhov stored in the holdings of the Rivne Museum of Local History (in 1947-1951 Serhyi Stekhov worked as head of the 2-N Department, in 1952-1953 - deputy head of the MSS department of Drohobych region).

33 Пограничные войска СССР 1945-1950. Сборник документов и материалов [ред. издат. А. Г. Синельников]. М.: Наука, 1975. 760 с.

34 “Особые папки” Сталіна і Молотова про національно-визвольну боротьбу в Західній Україні у 1944-1948 pр. / [упоряд. Ярослав Дашкевич; Василь Кук]. Львів: Піраміда, 2010. 594 с.

${ }^{35}$ Внутренние войска в борьбе с буржуазным националистическим подпольем на заключительном этапе Великой Отечественной войны и в первые послевоенные годы / [составители: Владимир Некрасов, Владимир Кривец, Михаил Горбов, Самуил Штутман]. М.: ГУВВ, 1986. 319 с.

${ }^{36}$ НКВД-МВД СССР в борьбе с бандитизмом и вооруженным националистическим подпольем на Западной Украине, в Западной Беларуссии и Прибалтике (1939-1956) / Сборник документов. [составители: Н. И. Владимирцев, А. И. Кокурин]. М.: Обьдиненная редакция МВС России, 2008. 640 с.

37 Украинские националистические организации в годы Второй мировой войны. Документи: в 2 т. / [под ред. А. Н. Артизова]. М.: Российская политическая энциклопедия (РОССПЭН), 2012. Т. 1: 1939-1943. 878 с.; Украинские националистические организации в годы Второй мировой войны. Документи: в 2 т./[под ред. А. Н. Артизова]. М.: Российская политическая энциклопедия (РОССПЭН), 2012. Т. 2: 1944-1945. 1167 с.

${ }^{38}$ Марчук І. Досьє полковника Стехова // Визвольний илях. 2008. Кн. 3. С. 175-188. 


\section{The Documents of party bodies}

The third group of documentary sources are the documents of party bodies. However, it should be emphasized that Soviet documents are subjective. When using them, it is necessary to take into account significant ideological stratification. Most of them are stored in the Central State Historical Museum of Ukraine (former archive of the Institute of Party History under the Central Committee of the Communist Party of Ukraine). The importance of the study of the materials of this archive lies in the fact that it was the communes, district committees, regional committees that were responsible for an armed and ideological struggle against the OUN and the URA. In general, the documents of this archive make it possible to reproduce the policy of the Soviet administration regarding the Sovietization of the region, to create an administrative, repressive and punitive apparatus, to find out the peculiarities of activity, forms and methods of combating the liberation movement. Specifically, fund 1 contains mainly policy documents (resolutions of party bodies, joint resolutions of party and state departments, decisions, transcripts of meetings of the $\mathrm{CK} \mathrm{CP}(\mathrm{b}) \mathrm{U}, \mathrm{CP}(\mathrm{b}) \mathrm{U}$ committees of the western region), information content (information of $\mathrm{CP}(\mathrm{b}) \mathrm{U}$ committees, reports of the power ministries), daily reports, special messages, information. These include the decision of the CK CP(b)U on the intensification of the struggle against Ukrainian nationalists and the shortcomings in the fight against them, the content of the secretaries of the primary party organizations and the results of the elections in the primary party organizations. The statistical reports of city councils, district committees of the Communist Party of Drohobych, Transcarpathia, Ivano-Frankivsk, Chernivtsi regional committees of the $\mathrm{CP}(\mathrm{b}) \mathrm{U}$ about the quantity of members, workers in certain spheres and the number of joined to the party. The part of the documents are copies and stored in the regional archives. In addition, analyzing the nature of the documents, we can state that they are the same as the materials found in SALR. Those that remained in place, after the collapse of the Soviet Union, were to be deposited in state archives. Drohobych, Transcarpathia, Ivano-Frankivsk, Chernivtsi regional committees of the $\mathrm{CP}(\mathrm{b}) \mathrm{U}$ prepared documents in several copies, one of which was sent to the Central Committee of the CP(b)U. Those that remained in regions, after the collapse of the Soviet Union, were to be deposited in state archives.

It should be noted that, immediately and partially after the collapse of the USSR, the so-called scrapping of "unwanted" documents was carried out both in the system of party (state) and KGB archives. As a result, a large array of documents was destroyed by the local staff, under the close 
supervision of colleagues at the center. Almost all the materials of the state archives of Transcarpathia, Chernivtsi regions on the fight against the PCIA-MIA and PCSS-MSS were gradually destroyed in October 1990. This is evidenced by the descriptions of the funds, which indicate the number of acts and the date of destruction against the respective category of cases. The documents of the party archives in the mentioned areas were cleaned professionally. A somewhat different situation in the State Archives of Ivano-Frankivsk region (SAIFR). The description was rewritten and no trace of destruction left. Although it is clear that the absence of a vast array of materials on the struggle of the authorities with the liberation movement is due to their elimination. There are no special files concerning special messages, reports on the fight in the SAIFR. Instead, a considerable number of them are preserved in the State Archives of Lviv region (SALR). Such data can only be obtained from the protocols of the meetings of the Stanislav department CP(b)U. Unlike Transcarpathia and Chernivtsi regions, in the SAIFR, probably because of the vast array of materials, the cases are preserved that indirectly reflect the activities of the OUN and the URA. This is mostly true of the documents covering the elections to the Supreme Soviet of the USSR, the fight of the underground against collectivization, the Komsomol, and so on. For the most part, there are cases in which the headlines did not explicitly mention the struggle against the nationalists and which do not contain a document on the crimes of the repressive and punitive system. The processing of descriptions allows to trace the extent of destruction of documents of the underground and repressive bodies, the correspondence of the Ministry of Internal Affairs with regional committees, district committees of the party and military units, prosecutor's office and court, materials of special check of the personnel of state bodies, activities of military tribunals, the materials of the elections to the Supreme Soviet of the USSR, the appeals and complaints of "workers" were varnished ${ }^{39}$. The rapid execution of orders and the extent of the destruction led to the fact that in the state archives of Transcarpathia and Chernivtsi regions it was not made appropriate markings in the descriptions, so it is impossible to find out the real picture p $^{40}$

The party documents on the struggle of the authorities with the nationalists are best preserved in the SALR (F. P-5001: Drohobych Regional Committee of the Communist Party (bolsheviks) of Ukraine $(\mathrm{CP}(\mathrm{b}) \mathrm{U})$, since October 1952 - CPU). It contains 12529 cases,

\footnotetext{
39 ДАІФО. Ф. 1. Оп. 1. Т. 1 (1946-1950 рр.). 140 арк.

40 ДАЧО. Ф. П-15. Оп. 1. Опис (1940-1971 рр.). 129 арк.; ДАЗО. Ф. П-1. Оп. 1. Опис (1946-1950). 140 арк.
} 
chronologically covering the years 1939-1941, 1943-1959 and containing transcripts and protocols of party meetings at different levels, the information on the preparation and holding of elections, special reports of the Ministry of Internal Affairs and information of the RC, MC, and the $\mathrm{CP}(\mathrm{b}) \mathrm{U}$ about the fight against the liberation movement. It was the party organs - regional committees, city committees and district committees which organized a large-scale armed and ideological struggle against the Ukrainian liberation movement, and under their leadership a repressive and punitive apparatus, which directly eliminated the underground. The overwhelming majority of the documents are memos of the Communist Party of Ukraine, the PCIA administration, the information of party district committees, the transcripts of meetings of party district secretaries, the information on the content of meetings on which issues were raised against Ukrainian nationalists, the staff of the secretaries of the primary party organizations and the results of the elections in primary party organizations. There is some informational in the statistic reports of city committees, district committees of the $\mathrm{CP}(\mathrm{b}) \mathrm{U}$ in Drohobych region about the number of members and candidates of the $\mathrm{CCP}(\mathrm{b})$ who work in certain sectors of the national economy, and about the number of candidates admitted to the party. There is the information about the number of underground fights, their characteristics, descriptions of armed attacks, prompt reports of the carried out operations, the lists of killed, captured, the information about the age of URA participants, the evictions of URA members' families, clearing of collective farms from unreliable persons, open trials over the participants of the URA (1949 p.). The important information was obtained from the memos of the PCIA-PCSS authorities not only on the course of the fight against the OUN and URA, but also on the quantitative status of the underground OUN and URA, the forms and methods of the fight against Soviet regime.

The cases in the State Archives of Transcarpathia Region (SATR) concerning the activities and combating underground were destroyed in October $1990^{41}$. A similar situation occurred in the State Archives of Chernivtsi region (SACR). The issues related to the fight against the underground and brought to the discussion of the regional council were added by separate documents that could not be found. At the same time, although it was "cleaned", in the State Archives of Ivano-Frankivsk Oblast (SAIFR) it was managed to find the information about the fight in the socalled protocol part of the committees and district committees. The documents from the funds of the Stanislav Regional Party (F. P-1), the Regional Executive Committee (F. P-295), the Regional Prosecutor's

${ }^{41}$ ДАЗО. Ф. П-1. Оп. 1. Арк. 7-9, 18, 25-27, 43, 60-61, 76, 90, 139 арк. 
Office (F. P-584), the Regional Military Commissariat (F. P-753) were also searched and processed. Among the sources found are resolutions, reporting documentation to higher party bodies, orders, information, analytical and statistical information.

In the state archives of Ivano-Frankivsk, Transcarpathia and Chernivtsi regions, among well-preserved documents, scripts and protocols of the meetings of the region and district party assets, political information, reports on the state and directions of development of industry and agriculture, advocacy work among the population, advocacy work with personnel, the information on the preparation and holding of elections to the Supreme Soviet of the USSR and local councils are of great importance. In other words, the documents on political, socio-economic and cultural development of these areas have been preserved. However, the information on the fight against the underground has been drawn from the general context.

When working with party documents of the specified category, they should be carefully separated through the ideological stamps and propaganda load they are saturated with: about "Ukrainian-German nationalists", "gangs of Ukrainian-German mercenaries", cooperation with special services of Germany, England, USA, etc.

The Institute of History of Ukraine of the NAS of Ukraine ${ }^{42}$ conducts considerable archaeographic work on the preparation and introduction to scientific circulation of the documents that cover the features and scope of the confrontation of the Ukrainian liberation movement with the Soviet totalitarian system. By their nature, both party and documents of the repressive and punitive bodies are included in the published collections.

A significant number of party documents from the archival institutions of Ukraine have been published in the new series of "the Chronicles of the URA" ${ }^{\prime 43}$, primarily from the funds of the State Historical and Historical

42 ОУН і УПА в 1945 році: Збірник документів і матеріалів. В 2 ч. Ч. 1 / [упоряд.: Веселова О.М. (відп. упоряд.), Гриневич В.А., Сергійчук В.І.; вступ: Лисенко О.С.]. К.: Інститут історії України НАН України, 2015. 371 с.; ОУН і УПА в 1945 році: Збірник документів і матеріалів. В 2 ч. Ч. 2 / [упоряд.: Веселова О.М. (відп. упоряд.), Гриневич В.А., Сергійчук В.І.]. К.: Інститут історії України НАН України, 2015. 366 с.

43 Літопис Української Повстанської Армії. Нова серія. Т. 3: Боротьба проти УПА і націоналістичного підпілля: директивні документи ЦК Компартії України. 1943-1959 / [упоряд. Олександр Вовк, Іван Павленко, Юрій Черченко]. К.; Торонто: Літопис УПА, 2001. 650 с.; Літопис Української Повстанської Армії. Нова серія. Т. 4: Боротьба проти УПА і націоналістичного підпілля: інформаційні документи ЦК КП(б)У, обкомів партії, НКВС-МВС, МДБ-КДБ (1943-1959) / [упоряд. Анатолій Кентій, Володимир Лозицький, Ірина Павленко]. К.; Торонто: Літопис УПА, 2002. Кн. 1: 1943-1945. 596 с.; Літопис Української Повстанської Армії. Нова серія. Т. 5: Боротьба проти УПА і націоналістичного підпілля: інформаційні документи ЦК КП(б)У, обкомів партії, НКВС-МВС, МДБ-КДБ (1943-1959) / [упоряд. Анатолій Кентій, Володимир Лозицький, Ірина Павленко]. К.; Торонто: Літопис УПА, 2002. Кн. 2: 1946-1947. 572 с.; Літопис Української Повстанської Армії. Нова серія. Т. 6: Боротьба проти УПА і націоналістичного підпілля: інформаційні документи ЦК КП(б)У, обкомів партії, НКВС-МВС, МДБ-КДБ (1943-1959) / [упоряд. Анатолій Кентій, Володимир Лозицький, Ірина Павленко, Катерина Абрамова]. К.; Торонто: Літопис УПА, 2003. Кн. 3: 1948. 523 с.; Літопис Української Повстанської Армії. Нова серія. Т. 7: Боротьба проти УПА i націоналістичного підпілля: інформаційні документи ЦК КП(б)У, обкомів партії, НКВС-МВС, МДБ-КДБ (1943-1959) / [упоряд. Михайло Деркач, Анатолій Кентій, Володимир Лозицький, Ірина Павленко]. К.; Торонто: Літопис УПА, 2003. Кн. 4: 1949-1959. 716 с. 
Museum of Ukraine. The documents are extremely important for covering the organization, forms and methods of the authorities' struggle against the underground of the Carpathian Regional Lead.

One of the first extensive archaeographic activities in the publication of party documents was launched by the famous researcher of the history of the liberation movement, Volodymyr Sergiychuk. A certain step forward, in comparison with the documentary works of his predecessors, was his collection, "OUN-URA in the Years of War", which was published in 1996. The book consists of a large number of underground, Soviet and German documents. The scientist continued his work on publication of documents in the following years. In particular, in an orderly collection of "Ten stormy years. Western Ukrainian Lands in 1944-1953" a large number of party documents is contained ${ }^{44}$. Extremely valuable are the documents collected by V. Sergiyuk were published in the collection under the general title "The Ukrainian Shift" 45 .

A large array of previously classified party documents revealing the scope of the struggle of the repressive-punitive apparatus against the liberation movement is centered in the three-volume "The Chronicle of Irresistible Ukraine", published under the general direction of Yaroslav Lyal'ka. However, the first two volumes have source value ${ }^{46}$. Also many memoirs of participants and eyewitnesses of the national liberation movement about the liberation struggle in the Carpathian region are published in these collections.

During the Soviet period, a number of published collections of documents on the Ukrainian liberation movement of the 1940s and 1950s were published, which are still being published. Their goal is to discredit, to denigrate the liberation struggle of national heroes, while rejecting the desire of Ukrainians to have their own state ${ }^{47}$.

${ }^{44}$ Сергійчук В. ОУН-УПА в роки війни. Нові документи і матеріали. К.: Дніпро, 1996. 496 с.; Сергійчук В. Десять буремних літ. Західноукраїнські землі у 1944-1953 pp. Нові документи і матеріали. К.: Дніпро, 1998. 944 с.

${ }^{45}$ Сергійчук В. Український здвиг: Волинь. 1939-1955 рр. К.: Українська Видавнича Спілка, 2005. 840 с.; Сергійчук В. Український здвиг: Закерзоння. 1939-1947 рр. К.: Українська Видавнича Спілка, 2004. 836 с.; Сергійчук В. Український здвиг: Наддніпрянщина. 1941-1955 pp. К.: Українська Видавнича Спілка, 2005. 836 с.; Сергійчук В. Український здвиг: Поділля. 1939-1955 рр. К.: Українська Видавнича Спілка, 2005. 840 с.; Сергійчук В. Український здвиг: Прикарпаття. 1939-1955 рр. К.: Українська Видавнича Спілка, 2005. 840 с.

46 Літопис нескореної України: Документи, матеріали, спогади / [підготували Ярослав Лялька, Петро Максимчук, Іван Патер та ін.; авт. передмови Ярослав Лялька, Роман Бачинський]. Львів: Просвіта, 1993. Кн. 1. 800 с.; Літопис нескореної України: Документи, матеріали, спогади / [підготували Ярослав Лялька, Роман Коритко, Мирон Онишкевич та ін.; авт. передмови Ярослав Лялька]. Львів: Галицька видавнича спілка, 1997. Кн. 2. 664 с.

47 Обвиняет земля. Организация украинских националистов: документы и материалы / [ред.-кол.: Виталий Масловский, Адам Мартынюк, Андрей Писловский, Владимир Помогаев, Руслан Пыриг]. М.: Универсум, 1991. 157 с. 


\section{The memories of participants of the Ukrainian national liberation movement}

The memoirs of the participants of the Ukrainian national liberation movement are an important source of comprehensive research, as they contain the characteristics of structure, leadership, reveal the forms and methods of the OUN's struggle against the establishment of the Soviet regime, and reveal the repressive policy of the official authorities against the underground. It should be emphasized that memoirs, although subjective, are not biased in some places, so the information must be carefully checked, and critically and comparatively analyzed. Instead, memories also have their advantage, because they convey the spirit of the time, the atmosphere of struggle, and provide the information that at one time could not be recorded in the documents of the underground or punitive bodies. A considerable number of them were written by the direct participants of the national liberation movement in "hot pursuit". An example is a sufficiently detailed biographical sketch of a SS referent, and hence the leader of the Dublin OUN District Office, Mikhailo Khariv "Shugay" 48 . Most notably, when writing a work on memoir sources, the work of the organizational referent of the OUN Stanislav districtprovid (07-08.1951), Petro Melnik "Khmara"49 was used. Following the instructions of the provid, he prepared his own memoirs, which have survived to this day. Equally valuable to us was the work of Stepan Frasuliak "Khmil" "50 the chief of military district (MD) "Hoverla" (1944). About his stay in the headquarters of the MD 5 "Makivka" wrote Stepan Fedorivskyi $^{51}$. The printer of OUN propaganda chief office Dariya Malyarchyn-Shpytal paid considerable attention to the rebels from Skole district $^{52}$.

In 2003, a collection of memoirs of the members of Drohobych OUN and the URA brotherhood under the title "You Will Get... or You Will Die..." 53 was started. The next collection under the same title was

\footnotetext{
${ }^{48}$ ГДА СБУ. Ф. 13. Спр. 376. Т. 47. Арк. 364-373.

49 Мельник Петро сотник УПА П. Хмара. В огні повстання. УПА на відтинку Чорного Лісу (1943-1945). Перша частина / [упоряд. Степан Лесів, Ярослав Коретчук]. Калуш: Карпатський акцент, 2014. $272 \mathrm{c}$.

${ }^{50}$ Ремесло повстанця. Збірник праць підполковника УПА Степана Фрасуляка-“Хмеля" / [ред. і упоряд. Р. Забілий]. Львів: Центр досліджень визвольного руху, 2007. 424 с.

${ }_{51}^{51}$ Федорівський С. Нотатки повстанця. Нью-Йорк: Прометей, 1962. 207 с.

52 I стали нам ті наші гори твердинею у лютий час... Спогади друкарки Головного осередку пропаганди ОУН і УПА Дарії Малярчин-Шпиталь / [ред.-упоряд. С. Онуфрів]. Львів: ПАІС, 2012. 164 с.; Малярчин-Шпиталь Д. Пам'яті Богдани Світлик // Пропам'ятна книга гімназї сестер Василіянок у Львові. Частина третя. Львів: Основа, 1995. С. 82-85.

53 “Здобудеш... або загинеш...” (Спогади ветеранів ОУН-УПА та наукові статті про національновизвольну боротьбу в 1940-1950-х рр. на Дрогобиччині) / [упоряд. Юрій Кишакевич]. Дрогобич: НВЦ “Каменяр” ДДПУ, 2003. Кн. 1. 172 с.
} 
published in $2007^{54}$. In the result of the field researches, the memories of direct participants and eyewitnesses of the national liberation movement were collected, organized and systematized, which became a kind of the continuation of the publications of memoirs, biographical references and martyrologists concerning the territory of the former Drohobych, Stanislav oblasts. These materials were enclosed in the book of memoirs "The Burning Way", edited by Vasily Ilnytskyi and Mykola Galiv". Dmytro Khorkavtsiv's reminiscences are rather informative, since they do not only cover the peculiarities of the life and preparation of the rebels, but also give unique testimonies of battles and persons information which were still unknown. Many memories relate to the life of the rebels, their clothing, food, wintering in the hiding places. The stories about the ways and methods of the Soviet special services' struggle with the nationalist underground are quite rich and detailed.

An important source for the study of the problem of functioning of the Ukrainian liberation movement in the OUN Carpathian region are the memoirs of the supporters Mariya Savchyn "Marichka", Stepan Stebelskyi "Hryn" and Oleksa Konopadskyi "Ostroverkh",57, published in the volumes of "The Chronicle of the URA. The book of memoirs about Mykola Tverdohlib "Grim" 58 was used in the monograph.

It is worth mentioning the historical and memoir trilogy of M. Andrusiak ${ }^{59}$. Despite the inaccuracies of the factual material and the fictional presentation, the memoir materials involved and the photoillustrated material collected are valuable.

Some researchers, including the author of this work, wrote down memories of participants in the liberation struggle of the 1940s and 1950s, who were directly related to the activities of the Carpathian region of the OUN. These records are kept in the private archives of those who carried them. Many of the collected and found memories relate to the everyday aspects of the life of the rebels, their clothing, food, wintering in the hiding places.

54 “Здобудеш... або загинеш...” (Спогади ветеранів ОУН-УПА про національно-визвольну боротьбу в 1940-1950-х pр. на Дрогобиччині) / [упоряд. Юрій Кишакевич, Микола Галів]. Дрогобич: Ред.-вид. відділ Дрогобицького державного педагогічного університету імені Івана Франка, 2007. Кн. 2. 190 с.

55 Шлях горіння: Спогади ветеранів ОУН і УПА про національно-визвольну боротьбу в 1940-1950-х рр. / [упоряд. Микола Галів, Василь Ільницький]. Дрогобич: Посвіт, 2008. 520 с.

56 Марія Савчин ("Марічка"). Тисячі доріг (Спогади) // Літопис Української повстанської армії [ред.-кол. Свген Штендера, Петро Потічний]. Торонто; Львів: Літопис УПА, 1995. Т. 28. 598 с.

57 Літопис Української Повстанської Армії. Т. 30: Степан Хрін (Степан Стебельський); Крізь сміх заліза: спогади / [ред. Петро Потічний]. Торонто: Літопис УПА, 2000. 552 с.

58 "Грім"- полковник УПА Микола Твердохліб. Спогади і матеріали / [упоряд. Грицьків Р.]. Торонто; Львів: Літопис УПА, 2008. Кн. 5.128 с. (Літопис УПА. Серія “Події і люди”).

${ }_{59}$ Андрусяк М. Брати вогню. Коломия: Вік, 2004. 832 с.; Андрусяк М. Брати грому. Коломия: Вік, 2005. 832 с.; Андрусяк М. Брати просторів. Коломия: Вік, 2007. 840 с; Андрусяк М. Грані болю [Текст]: док. оповіді про УПА. Коломия: Вік, 1994. 198 с. 
To important, extremely informative sources that help to cover this problem in the complex are included personal documents, epistolary art, photos, things of the underground and their relatives, graves with corresponding inscriptions, hiding places, as well as the remains of underground archives. A unique photo archive was managed to organize and process by Vasily Humeniuk ${ }^{60}$. These photos, in addition to transmitting of images of the insurgents themselves, complement significantly the notion of daily life, weapons, and partly the relationship among nationalists.

\section{Periodicals}

We cannot avoid such a valuable source for covering the topic of the study as the periodicals (official Soviet and OUN and URA). It is clear that the Soviet press pursued a party line that had the task of carrying out propaganda treatment of the population and combating the ideology of nationalism. The paper also used publications from periodicals and underground press and the OUN's press bodies, including the underground and insurgent publications "Idea i Chyn" ("Idea and Post"), "Shlyah peremogy" ("The Way of Victory"), "Chornyi Lis" ("The Black Forest"), "Revolucioner-propagandyst" ("A Revolutionary-Proponent"), "Do Zbroii" ("To Arms")", Povstanets" ("A Rebel") and Soviet editions (newspapers of regional $\mathrm{CP}(\mathrm{b}) \mathrm{U}$ "Zakarpatska Pravda", "Soviet Bukovina", "A Soviet Word", "Precarpathian Pravda", as well as regional periodicals) ${ }^{61}$.

\section{CONCLUSIONS}

Thus, the decades-long rebel struggle in the Carpathian region (1945-1954) left a huge documentary legacy. The archives of different levels contain documents that comprehensively characterize the liberation struggle of the Ukrainian people. The presence of various documents by origin, authenticity and content of documents makes it possible to study different aspects of the activities of the national liberation movement systematically, to recreate its structure and to show the directions of repressive policy of the authorities towards the nationalists of the Carpathian region of the OUN (second half of the 40s - the first half of the 1950s). At the same time, it should be remembered that the widest possible and comprehensive use of different types of sources, their comparison

${ }^{60}$ Гуменюк В., Яким’юк С. Повстанські світлини зі сховку Володимира Яким'юка “Аскольда”. Львів: ПП Сорока Т.Б., 2007. 144 с.; Гуменюк В., Яким’юк С. Повстанські світлини зі сховку Володимира Якимюка “Аскольда". Львів: ПП Сорока Т.Б., 2007. 144 с.; Гуменюк В. Фотограф УПА “Липкевич”// Украӥнський визвольний рух. Львів: Мс, 2003. Збірник 1. С. 159-164.

61 Літопис Української Повстанської Армії. Нова серія. Т. 1: Видання Головного Командування УПА / [упоряд. Олександр Вовк, Василь Галаса, Юрій Черченко]. К.; Торонто: Літопис УПА, 1995. 482 с. 
makes it possible to verify the accuracy of the data and to ascertain the real situation in crayovyi provid of the OUN of the Carpathian region sufficiently and objectively.

\section{SUMMARY}

It is established that as a result of the 10-year rebel struggle in the Carpathian region (1945-1954), there is a huge documentary heritage, characterized by origin, place of storage, representativeness of historical facts, manning methods, degree of disclosure of certain aspects of the problem. Depending on the origin or authorship in the broad sense, the whole source complex can be divided into five groups: 1) OUN and URA documents; 2) The documents of the repressive and punitive bodies of the USSR; 3) The documents of party bodies; 4) The memories of the participants of the Ukrainian national liberation movement; 5) periodicals. The presence of various documents by origin, authenticity and content of documents makes it possible to study different aspects of the activities of the national liberation movement systematically, to recreate its structure and to show the directions of repressive policy of the authorities towards the nationalists of the Carpathian region of the OUN (second half of the $40 \mathrm{~s}$ - the first half of the 1950s). At the same time, it should be remembered that the widest possible and comprehensive use of different types of sources, their comparison makes it possible to verify the accuracy of the data and to ascertain the real situation in crayovyi provid of the OUN of the Carpathian region sufficiently and objectively.

\section{REFERENCES}

1. АБН в світлі постанов Конференцій та інших матеріялів 3 діяльности 1941-1956 рр. [Б. м.]: Вид. ЗЧ ОУН, 1956. 368 с.

2. Андрусяк М. Брати просторів. Коломия: Вік, 2007. 840 с.

3. Андрусяк М. Грані болю [Текст]: док. оповіді про УПА. Коломия: Вік, 1994. 198 с.

4. Андрусяк М. Брати вогню. Коломия: Вік, 2004. 832 с.

5. Андрусяк М. Брати грому. Коломия: Вік, 2005. 832 с.

6. Білас I. Репресивно-каральна система в Україні 1917-1953. Суспільно-політичний та історичний аналіз. У двох книгах. К.: Либідь; Військо України, 1994. Книга друга: Документи та матеріали. $688 \mathrm{c}$.

7. Внутренние войска в борьбе с буржуазным националистическим подпольем на заключительном этапе Великой Отечественной войны и в первые послевоенные годы / [составители: Владимир 
Некрасов, Владимир Кривец, Михаил Горбов, Самуил Штутман]. М.: ГУВВ, 1986. 319 с.

8. Галузевий державний архів Служби безпеки України (далі ГДА СБУ). Ф. 2-Н. Оп. 54 (1953). Спр. 3. Т. 1.

9. ГДА СБУ. Ф. 2-Н. Оп. 55 (1953). Спр. 5. Т. 1.

10. ГДА СБУ. Ф. 2-Н. Оп. 59 (1953). Спр. 6. Т. 4.

11. ГДА СБУ. Ф. 2-Н. Оп. 59 (1953). Спр. 7. Т. 2.

12. ГДА СБУ. Ф. 2-Н. Оп. 60 (1953). Спр. 3. Т. 5.

13. ГДА СБУ. Ф. 2-Н. Оп. 67 (1953). Спр. 11.

14. ГДА СБУ. Ф. 2-Н. Оп. 93 (1954). Спр. 1.

15. ГДА СБУ. Ф. 2-Н. Оп. 93 (1954). Спр. 2.

16. ГДА СБУ. Ф. 2-Н. Оп. 98 (1954). Спр. 1. Т. 2.

17. ГДА СБУ. Ф. 2-Н. Оп. 110 (1954). Спр. 2. Т. 5.

18. ГДА СБУ. Ф. 2-Н. ОП. 110 (1954). Спр. 2. Т. 6.

19. ГДА СБУ. Ф. 2-Н. Оп. 110 (1954). Спр. 2. Т. 7.

20. ГДА СБУ. Ф. 2-Н. Оп. 110 (1954). Спр. 2. Т. 8.

21. ГДА СБУ. Ф. 2-Н. Оп. 28 (1960). Спр. 16.

22. ГДА СБУ. Ф. 2-Н. Оп. 28 (1960). Спр. 17.

23. ГДА СБУ. Ф. 2-Н. Оп. 28 (1960). Спр. 20.

24. ГДА СБУ. Ф. 13. Спр. 372. Т. 1.

25. ГДА СБУ. Ф. 13. Спр. 372. Т. 2.

26. ГДА СБУ. Ф. 13. Спр. 372. Т. 4.

27. ГДА СБУ. Ф. 13. Спр. 372. Т. 5.

28. ГДА СБУ. Ф. 13. Спр. 372. Т. 6.

29. ГДА СБУ. Ф. 13. Спр. 372. Т. 9.

30. ГДА СБУ. Ф. 13. Спр. 372. Т. 16.

31. ГДА СБУ. Ф. 13. Спр. 372. Т. 18.

32. ГДА СБУ. Ф. 13. Спр. 372. Т. 23.

33. ГДА СБУ. Ф. 13. Спр. 372. Т. 26.

34. ГДА СБУ. Ф. 13. Спр. 372. Т. 53.

35. ГДА СБУ. Ф. 13. Спр. 372. Т. 56.

36. ГДА СБУ. Ф. 13. Спр. 372. Т. 77.

37. ГДА СБУ. Ф. 13. Спр. 376. Т. 47.

38. ГДА СБУ. Ф. 13. Спр. 398. Т. 13.

39. ГДА СБУ. Ф. 65. Спр. 9079. Т. 52.

40. ГДА СБУ. Ф. 65. Спр. 7443.

41. ГДА СБУ. Ф. 65. Спр. 7443.

42. ГДА СБУ. Ф. 65. Спр. 8707. Т. 1.

43. ГДА СБУ. Ф. 65. Спр. 9112. Т. 17.

44. ГДА СБУ. Ф. 65. Спр. С-9159.

45. ГДА СБУ. Ф. 65. Спр. С-9186. Т. 1-2. 
46. ГДА СБУ. Ф. 71. Оп. 6. Спр. 203.

47. ГДА СБУ. Ф. 71. Опис фонду.

48. "Грім"-полковник УПА Микола Твердохліб. Спогади i матеріали / [упоряд. Грицьків Р.]. Торонто; Львів: Літопис УПА, 2008. Кн. 5.128 с. (Літопис УПА. Серія "Події і люди”).

49. Гуменюк В. Фотограф УПА “Липкевич” // Украӥнський визвольний рух. Львів: Мс, 2003. Збірник 1. С. 159-164.

50. Гуменюк В., Яким'юк С. Повстанські світлини зі сховку Володимира Яким'юка “Аскольда”. Львів: ПП Сорока Т.Б., 2007. $144 \mathrm{c}$.

51. Гуменюк В., Яким'юк С. Повстанські світлини зі сховку Володимира Якимюка “Аскольда". Львів: ПП Сорока Т.Б., 2007. $144 \mathrm{c}$.

52. Державний архів Закарпатської області (далі - ДАЗО). Ф. П-1. Оп. 1. Опис (1946-1950).

53. Державний архів Івано-Франківської області (далі - ДАІФО). Ф. 1. Оп. 1. Т. 1 (1946-1950 рр.).

54. Державний архів Чернівецької області (далі - ДАЧО). Ф. П-15. Оп. 1. Опис (1940-1971 рр.).

55. Депортації: Західні землі України кінця 30-х - початку 50-х pp. Документи, матеріали, спогади. У трьох томах / [упоряд. Юрій Сливка]. Львів: Інститут українознавства імені Івана Крип'якевича НАН України, 1996. Т. 1: 1939-1945 pp. 750 с.

56. Депортації: Західні землі України кінця 30-х-початку 50-х рр. Документи, матеріали, спогади. У трьох томах. / [упоряд. Юрій Сливка]. Львів: Інститут українознавства імені Івана Крип'якевича НАН України, 1998. Т. 2: 1946-1947 pp. 540 с.

57. Діяльність Служби безпеки ОУН на Дрогобиччині: документи і матеріали (1944-1951) / [упоряд. Василь Ільницький, Микола Галів; передмова - Василь Ільницький, примітки - Микола Галів]. Кн. 1. Дрогобич: Швидкодрук, 2009. 264 с.

58. I стали нам ті наші гори твердинею у лютий час... Спогади друкарки Головного осередку пропаганди ОУН i УПА Дарії Малярчин-Шпиталь / [ред.-упоряд. С. Онуфрів]. Львів: ПАІС, 2012. 164 c.

59. “ Здобудеш... або загинеш...” (Спогади ветеранів ОУН-УПА та наукові статті про національно-визвольну боротьбу в 1940-1950-х рр. на Дрогобиччині) / [упоряд. Юрій Кишакевич]. Дрогобич: НВЦ “Каменяр” ДДПУ, 2003. Кн. 1. 172 с.

60. “Здобудеш... або загинеш...” (Спогади ветеранів ОУН-УПА про національно-визвольну боротьбу в 1940-1950-х pp. на 
Дрогобиччині) / [упоряд. Юрій Кишакевич, Микола Галів]. Дрогобич: Ред.-вид. відділ Дрогобицького державного педагогічного університету імені Івана Франка, 2007. Кн. 2. 190 с.

61. Літопис нескореної України: Документи, матеріали, спогади / [підготували Ярослав Лялька, Петро Максимчук, Іван Патер та ін.; авт. передмови Ярослав Лялька, Роман Бачинський]. Львів: Просвіта, 1993. Кн. 1.800 с.

62. Літопис нескореної України: Документи, матеріали, спогади / [підготували Ярослав Лялька, Роман Коритко, Мирон Онишкевич та ін.; авт. передмови Ярослав Лялька]. Львів: Галицька видавнича спілка, 1997. Кн. 2. 664 с.

63. Літопис Української Повстанської Армії. Т. 3: Чорний ліс: видання команди Станиславівського тактичного відтинка УПА 1947-1948 роки. Передрук підпільного журналу УПА (1947-1948) / [відп. ред. С. Штендера, співред. П. Потічний]. Торонто: Літопис УПА, 1978. Кн. 1. 272 с.

64. Літопис Української Повстанської Армії. Т. 4: Чорний ліс: видання команди Станиславівського тактичного відтинка УПА 1947-1950 роки. (1948-1950) / [відп. ред. С. Штендера, співред. П. Потічний]. Торонто: Літопис УПА, 1979. Кн. 2. 288 с.

65. Літопис Української Повстанської Армії. Т. 8: Українська Головна Визвольна Рада; документи, офіційні публікації, матеріали / [ред.-кол. Євген Штендера, Петро Потічний]. - Торонто: Літопис УПА, 1980. Кн. 1: 1944-1945. 320 с.

66. Літопис Української Повстанської Армії. Т. 9: Українська Головна Визвольна Рада. Документи, офіційні публікації, матеріяли / [ред.-кол. Свген Штендера, Петро Потічний]. Торонто: Літопис УПА, 1982. Кн. 2: 1946-1948. 520 с.

67. Літопис Української Повстанської Армії. Т. 10: Українська Головна Визвольна Рада. Документи, офіційні публікації, матеріяли / [ред.-кол. Свген Штендера, Петро Потічний]. Торонто: Літопис УПА, 1984. Кн. 3: 1949-1952. 424 с.

68. Літопис Української Повстанської Армії. Т. 18: Група УПА "Говерля". Документи, звіти та офіційні публікації / [упоряд. Петро Содоль]. Торонто: Літопис УПА, 1990. Кн. 1.328 с.

69. Літопис Української Повстанської Армії. Т. 19: Група УПА "Говерля". Спомини, статті та видання історично-мемуарного характеру / [упоряд. Петро Содоль]. Торонто; Львів: Літопис УПА, 1992. Кн. 2. 360 c. 
70. Літопис Української Повстанської Армії. Т. 23: Медична опіка в УПА [упоряд. Петро Содоль]. Торонто; Львів: Літопис УПА, 1992. $480 \mathrm{c}$.

71. Літопис Української Повстанської Армії. Т. 24: Ідея і чин: Орган Проводу ОУН, 1942-1946 / [ред.-кол. Юрій Маївський, Євген Штендера]. Торонто; Львів: Літопис УПА, 1996. 342 с.

72. Літопис Української Повстанської Армії. Т. 26: Українська Головна Визвольна Рада / [ред. Петро Потічний]. Торонто; Львів: Літопис УПА, 2001. Кн. 4: Документи і спогади. 658 с.

73. Літопис Української Повстанської Армії. Т. 30: Степан Хрін (Степан Стебельський); Крізь сміх заліза: спогади / [ред. Петро Потічний]. Торонто: Літопис УПА, 2000. 552 с.

74. Літопис Української Повстанської Армії. Т. 32: Медична опіка в УПА: документи, матеріяли і спогади / [ред. Модест Ріпецький]. Торонто; Львів: Літопис УПА, 2001. Кн. 2. 581 с.

75. Літопис Української Повстанської Армії. Т. 38: Архітектура резистансу: криївки і бункери УПА в світлі радянських документів / [ред. Петро Потічний]. Торонто; Львів: Літопис УПА, 2002. 430 с.

76. Літопис Української Повстанської Армії. Нова серія. Т. 1: Видання Головного Командування УПА / [упоряд. Олександр Вовк, Василь Галаса, Юрій Черченко]. К.; Торонто: Літопис УПА, 1995. $482 \mathrm{c}$.

77. Літопис Української Повстанської Армії. Нова серія. Т. 4: Боротьба проти УПА і націоналістичного підпілля: інформаційні документи ЦК КП(б)У, обкомів партії, НКВС-МВС, МДБ-КДБ (1943-1959) / [упоряд. Анатолій Кентій, Володимир Лозицький, Ірина Павленко]. К.; Торонто: Літопис УПА, 2002. Кн. 1: 1943-1945. 596 с.;

78. Літопис Української Повстанської Армії. Нова серія. Т. 5: Боротьба проти УПА і націоналістичного підпілля: інформаційні документи ЦК КП(б)У, обкомів партії, НКВС-МВС, МДБ-КДБ (1943-1959) / [упоряд. Анатолій Кентій, Володимир Лозицький, Ірина Павленко]. К.; Торонто: Літопис УПА, 2002. Кн. 2: 1946-1947. 572 с.

79. Літопис Української Повстанської Армії. Нова серія. Т. 6: Боротьба проти УПА і націоналістичного підпілля: інформаційні документи ЦК КП(б)У, обкомів партії, НКВС-МВС, МДБ-КДБ (1943-1959) / [упоряд. Анатолій Кентій, Володимир Лозицький, Ірина Павленко, Катерина Абрамова]. К.; Торонто: Літопис УПА, 2003. Кн. 3: 1948. 523 c.

80. Літопис Української Повстанської Армії. Нова серія. Т. 7: Боротьба проти УПА і націоналістичного підпілля: інформаційні документи ЦК КП(б)У, обкомів партії, НКВС-МВС, МДБ-КДБ 
(1943-1959) / [упоряд. Михайло Деркач, Анатолій Кентій, Володимир Лозицький, Ірина Павленко]. К.; Торонто: Літопис УПА, 2003. Кн. 4: 1949-1959. $716 \mathrm{c.}$

81. Літопис Української Повстанської Армії. Нова серія. Т. 9: Боротьба проти повстанського руху і націоналістичного підпілля: протоколи допитів заарештованих радянськими органами державної безпеки керівників ОУН і УПА / [упоряд. Олександр Іщук, Сергій Кокін]. 1944-1945. К.; Торонто: Літопис УПА, 2007. 912 с.

82. Літопис Української Повстанської Армії. Нова серія. Т. 15: Боротьба проти повстанського руху i націоналістичного піпілля: протоколи допитів заарештованих радянськими органами державної безпеки керівників ОУН і УПА. 1945-1954 / [упоряд. С. Власенко, С. Кокін, В. Лозицький]. К.; Торонто: Літопис УПА, 2011. Кн. 2.840 c.

83. Літопис Української Повстанської Армії. Нова серія. Т. 19: Підпілля ОУН на Буковині: Документи і матеріали. 1943-1951 / [упоряд. Дмитро Проданик]. К.; Торонто: Літопис УПА, 2012. 840 с.

84. Літопис Української Повстанської Армії. Нова серія. Т. 22: Станиславівська округа ОУН: документи і матеріали 1945-1951 / [упоряд. Дмитро Проданик, Степан Лесів]. К.; Торонто: Літопис УПА, 2013. $1376 \mathrm{c.}$

85. Літопис Української Повстанської Армії. Нова серія. Т. 25: Коломийська округа ОУН: документи і матеріали 1945-1952 / [упоряд. Дмитро Проданик, Василь Гуменюк]. К.; Торонто: Літопис УПА, 2015. $1104 \mathrm{c.}$

86. Літопис Української Повстанської Армії. Нова серія. Т. 3: Боротьба проти УПА i націоналістичного підпілля: директивні документи ЦК Компартії України. 1943-1959 / [упоряд. Олександр Вовк, Іван Павленко, Юрій Черченко]. К.; Торонто: Літопис УПА, $2001.650 \mathrm{c}$.

87. Малярчин-Шпиталь Д. Пам'яті Богдани Світлик // Пропам'ятна книга гімназї сестер Василіянок у Львові. Частина третя. Львів: Основа, 1995. С. 82-85.

88. Марія Савчин (“Марічка”). Тисячі доріг (Спогади) // Літопис Української повстанської армії [ред.-кол. Свген Штендера, Петро Потічний]. Торонто; Львів: Літопис УПА, 1995. Т. 28. 598 с.

89. Марчук І. Досьє полковника Стехова // Визвольний шлях. 2008. Кн. 3. С. 175-188.

90. Мельник Петро сотник УПА П. Хмара. В огні повстання. УПА на відтинку Чорного Лісу (1943-1945). Перша частина / 
[упоряд. Степан Лесів, Ярослав Коретчук]. Калуш: Карпатський акцент, 2014. 272 с.

91. Мороз В. 3 листування членів Проводу ОУН (листопад 1944 травень 1945) // Український визвольний рух. Львів, 2007. Збірник 10: До 100-річчя від дня народження Романа Шухевича. С. 34-52.

92. Національні процеси в Україні: історія і сучасність. Документи i матеріали. Довідник: В 2 ч. / [упоряд. I.О. Кресіна (керівник), О.В. Кресів, В.П. Ляхоцький, В.П. Панібудьласка]. К.: Вища школа, 1997. Ч. 1. 583 с.

93. Національні процеси в Україні: історія і сучасність. Документи і матеріали. Довідник: В 2 ч./ [упоряд. I. О. Кресіна (керівник), О.В. Кресів, В.П. Ляхоцький, В.П. Панібудьласка]. К.: Вища школа, 1997. Ч. 2.704 с.

94. НКВД-МВД СССР в борьбе с бандитизмом и вооруженным националистическим подпольем на Западной Украине, в Западной Беларуссии и Прибалтике (1939-1956) / Сборник документов. [составители: Н.И. Владимирцев, А.И. Кокурин]. М.: Обьдиненная редакция МВС России, 2008. 640 с.

95. Обвиняет земля. Организация украинских националистов: документы и материалы / [ред.-кол.: Виталий Масловский, Адам Мартынюк, Андрей Писловский, Владимир Помогаев, Руслан Пыриг]. М.: Универсум, 1991. 157 с.

96. “Особые папки” Сталіна і Молотова про національновизвольну боротьбу в Західній Україні у 1944-1948 рр./ [упоряд. Ярослав Дашкевич; Василь Кук]. Львів: Піраміда, 2010. $594 \mathrm{c}$.

97. ОУН в світлі постанов Великих Зборів, Конференцій та інших документів з боротьби 1929-1955. [Б.м.]: Видання Закордонних частин ОУН, 1955. 372 с. (“Бібліотека українського підпільника” Ч. 1).

98. ОУН і УПА в 1945 році: Збірник документів і матеріалів. В 2 ч. Ч. 1 / [упоряд.: Веселова О.М. (відп. упоряд.), Гриневич В.А., Сергійчук В.I.; вступ: Лисенко О.С.]. К.: Інститут історії України НАН України, 2015. 371 с.

99. ОУН і УПА в 1945 році: Збірник документів і матеріалів. В 2 ч. Ч. 2 / [упоряд.: Веселова О. М. (відп. упоряд.), Гриневич В.А., Сергійчук В.I.]. К.: Інститут історії України НАН України, 2015. $366 \mathrm{c.}$

100. Папакін Г. Українські визвольні змагання 1939-1956: джерельний контент. Вип. 1. Проблеми класифікації й змісту джерел повстанського та радянського походження / [відп. ред. Г. Боряк] / Інститут історії України НАН України. К., 2012. 358 с. 
101. Пограничные войска СССР 1945-1950. Сборник документов и материалов [ред. издат. А. Г. Синельников]. М.: Наука, 1975. 760 с.

102. Польсько-українські стосунки в 1942-1947 роках у документах ОУН та УПА: у 2 т. / [відп. ред. та упоряд. В. В'ятрович]. Львів: Центр досліджень визвольного руху, 2011. Т. 1: Війна під час війни (1942-1945). 792 с.

103. Польсько-українські стосунки в 1942-1947 роках у документах ОУН та УПА: у 2 т. / [відп. ред. та упоряд. В. В'ятрович]. Львів: Центр досліджень визвольного руху, 2011. Т. 2: Війна після війни (1945-1947). 576 с.

104. Ремесло повстанця. Збірник праць підполковника УПА Степана Фрасуляка - "Хмеля" / [ред. і упоряд. Р. Забілий]. Львів: Центр досліджень визвольного руху, 2007. 424 с.

105. Роман Шухевич у документах радянських органів державної безпеки (1940-1950). К.: ПП Сергійчук М. I., 2007. Т. 1. $640 \mathrm{c.}$

106. Роман Шухевич у документах радянських органів державної безпеки (1940-1950). К.: ПП Сергійчук М. I., 2007. T. 2.584 c.

107. Сергійчук В. Десять буремних літ. Західноукраїнські землі у 1944-1953 pр. Нові документи і матеріали. К.: Дніпро, 1998. 944 с.

108. Сергійчук В. Депортація поляків 3 України. Невідомі документи про насильницьке переселення більшовицькою владою польського населення з УРСР в Польщу в 1944-1946 роках. К.: Українська видавнича спілка, 1999. 191 с.; Сергійчук В. Самі себе звоювали. Діяльність винищувальних батальйонів проти українського національно-визвольного руху. К.: Українська видавнича спілка. 80 с.

109. Сергійчук В. ОУН-УПА в роки війни. Нові документи i матеріали. К.: Дніпро, 1996. 496 с.

110. Сергійчук В. Тавруючи визвольний прапор. Діяльність агентури та спецбоївок НКВС-НКДБ під виглядом ОУНУПА. Видання друге, доповнене. К.: ПП Сергійчук М.I., 2006. 184 с.

111. Сергійчук В. Український здвиг: Волинь. 1939-1955 pp. К.: Українська Видавнича Спілка, 2005. 840 с.

112. Сергійчук В. Український здвиг: Закерзоння. 1939-1947 pp. К.: Українська Видавнича Спілка, 2004. 836 с.

113. Сергійчук В. Український здвиг: Наддніпрянщина. 1941-1955 рр. К.: Українська Видавнича Спілка, 2005. 836 с.

114. Сергійчук В. Український здвиг: Поділля. 1939-1955 рр. К.: Українська Видавнича Спілка, 2005. 840 с. 
115. Сергійчук

В. Український

здвиг:

Прикарпаття. 1939-1955 рр. К.: Українська Видавнича Спілка, 2005. 840 с.

116. УГВР в світлі постанов Великого Збору та інших документів 3 діяльности 1944-1951 pp. [Б.м.]: Видання Закордонних частин ОУН, 1956.356 с. (Серія "Бібліотека українського підпільника" Ч. 3)

117. Украинские националистические организации в годы Второй мировой войны. Документи: в 2 т. / [под ред. А. Н. Артизова]. М.: Российская политическая энциклопедия (РОССПЭН), 2012. Т. 1: 1939-1943. $878 \mathrm{c.}$

118. Украинские националистические организации в годы Второй мировой войны. Документи: в 2 т. / [под ред. А. Н. Артизова]. М.: Российская политическая энциклопедия (РОССПЭН), 2012. Т. 2: 1944-1945. 1167 с.

119. Український національно-визвольний рух на Прикарпатті в XX столітті. Документи i матеріали / [відп. ред. проф. Микола Кугутяк]. Т. 2. Івано-Франківськ: КПФ “ЛІК”, 2009. Кн. 1: 1939-1945. $600 \mathrm{c}$.

120. Український національно-визвольний рух на Прикарпатті в XX столітті. Документи і матеріали / [відп. ред. проф. Микола Кугутяк]. Т. 2. Івано-Франківськ: КПФ “ЛІК”, 2010. Кн. 2: 1945-1946. $696 \mathrm{c}$.

121. Український національно-визвольний рух на Прикарпатті в XX столітті. Документи i матеріали / [відп. ред. проф. Микола Кугутяк]. Т. 2. Івано-Франківськ: КПФ “ЛІК”, 2011. Кн. 3: 1947-1957. $768 \mathrm{c}$.

122. УПА в світлі документів 3 боротьби за Українську Самостійну Соборну Державу 1942-1950 pp. [Б.м.]: Видання Закордонних частин ОУН, 1957. Ч. 1. 452 с. (Серія “Бібліотека українського підпільника" Ч. 6)

123. УПА в світлі документів 3 боротьби за Українську Самостійну Соборну Державу 1942-1950 рр. Бойові дії УПА за 1943-1950 pр. [Б.м.]: Видання Закордонних частин ОУН, 1960. Ч. 2. 444 с. (Серія "Бібліотека українського підпільника" Ч. 7)

124. Федорівський С. Нотатки повстанця. Нью-Йорк: Прометей, 1962. $207 \mathrm{c}$.

125. Центральний державний архів вищих органів влади та управління України (далі - ЦДАВО України). Ф. 3833. Оп. 1. Спр. 226.

126. ЦДАВО України. Ф. 3836. Оп. 1. Спр. 67.

127. ЦДАВО України. Ф. 3836. Оп. 1. Спр. 70. 
128. ЦДАВО України. Ф. 3838. Оп. 1. Спр. 4а.

129. ЦДАГО України. Ф. 1. Оп. 23. Спр. 2968.

130. Шлях горіння: Спогади ветеранів ОУН і УПА про національно-визвольну боротьбу в 1940-1950-х pp./ [упоряд. Микола Галів, Василь Ільницький]. Дрогобич: Посвіт, 2008. 520 с.

\section{Information about the author:} Inytskyi V. I.

Doctor of Historical Sciences, Associate Professor, Head of the Department of Ukraine's History, Ivan Franko Drohobych State Pedagogical University 46, Lesya Ukrainka str., Drohobych, Lviv region., 82100, Ukraine 


\section{PEASANTRY AS THE MAIN MILITARY FORCE DURING UKRAINIAN REVOLUTION PERIOD 1917-1921 ${ }^{1}$}

\section{Masnenko V. V.}

\section{INTRODUCTION}

The modern period was the time of social transformations of the humanity. The main tendency was the demolition of traditional society in all aspects of being. Another feature was the mass character of political life (alongside with the development of parliamentary system and mass political parties). The social roles and behaviors of different social layers changed as well. The emancipation of peasantry, in its broader meaning, was one of the leading tendencies of the general process of modernization. The determining factor that accelerated this process was the emerging of mass army with the mechanism of conscription. In agrarian societies the peasantry was the main component of military service.

Ukrainian peasantry in Russian empire was a latecomer to this modernization process. However, it only slowed down its emancipation and it accelerated only during the World War I and the following revolutionary events.

The aim is to investigate the peculiarities of Ukrainian peasantry militarization that determined its leading role in the events of Ukrainian revolution 1917-1921, including the participation in regular armies, rebellion movement and peasantry war.

\section{During the World War I}

The World War I was the turning point of the modernization. Millions of peasants were torn apart from their traditional agrarian lifestyle and peasant world; they lost the connection with their usual way of keeping the household. Such a drastic catastrophic event could not but substantially transform the peasant's outlook. Researchers have already noticed the peculiarities of this process. For instance, Russian historian O. Gordon stated, that the peasantry at war radically and profoundly tears all the links with the previous, the peasant lifestyle and it cannot return to it. In overall, the war destroys the very essence of the peasants' outlook - the cyclical world perception, the established routine, the belonging to the "soil", etc, thus, the war triggered the mass "de-peasantation". If a peasant became a

\footnotetext{
${ }^{1}$ Publication contains the results of studies conducted on the implementation of the state budget theme «The Ukrainian Revolution (1917-1921): the peasant factor» (№ 0118U003864)
} 
revolutionary, there was no way back for him ${ }^{2}$. The last statement requires some correction, taking into account the fact, that the peasant-soldier during revolution did come back, but he was a different person - the one that responds to extreme challenges with radical actions.

Unprecedented death toll, the place of technology in mass homicide, the level of violence - all these factors influenced the mobilized army of peasantry even during the time of peace. As O. Porshneva claims, they were "on the other side" of moral and religious norms and prohibitions, which caused the changes in their perception of the boundaries of allowed violence, the value of human life, the significance of religious faith ${ }^{3}$. We can agree with V. Lozovyi that in military circumstances a full reevaluation of moral basics and religious values from Christian principle "Do not kill" to the military imperative: "Kill the enemy" took place. Marauder robbery of the civil population on the conquered territories was acceptable without saying. The basic assumptions of peasants about sins, the fear of God and other people were destroyed as well ${ }^{4}$.

On the other hand, even in new military conditions the peasantry still preserved some solely rural peculiarities of the world perception. As O. Mykhailiuk states: "The peasantry strived for localization, destruction of any authority that was higher than the local one, which objectively led to archaizing of the social life and excluded any statehood. Thus, the ideas and actions of the peasantry were incompatible with the policies of almost all state and political units".

The immediate participation of peasantry in violent actions led to the enforcement of psychological "setting" for cruelty in an enormous multimillion mass of people, the development of militarized consciousness, tendency for extreme violent actions, and devaluation of a human life. The Orthodox faith of peasants-soldiers, as O. Porshneva thinks, faced a serious outlook challenge during the war. As a result, Christian ethical norms and values were devaluated in the consciousness of masses, which prepared the ground for inherent (in the mentality of a traditional plowman) pagan beliefs, archaic mental stereotypes that in a bizarre way merged with rationalist principles that came from modernization and technical progress.

\footnotetext{
2 Русское крестьянство и Первая мировая война : международный круглый стол / публ. П.П. Марчени, С.Ю. Разина. Новый исторический вестник. 2014. № 2 (40). С. 8-89.

${ }^{3}$ Поршнева О.С. Крестьяне, рабочие и солдаты России накануне и в годы Первой мировой войнь. Москва: РОССПЭН, 2004. С. 115.

4 Лозовий В. Солдати і дестабілізація суспільно-політичного становищ а: вплив Першої світової війни на революційні процеси в Україні (1917р.). Вісник Київського національного університету імені Тараса Шевченка. Історія. 2014. № 3 (121 ). С. 22.

${ }^{5}$ Поршнева О.С. Менталитет и сочиальное поведение рабочих, крестьян и солдат России в годы Первой мировой войны (1914 март 1918): Дисс. ... д-р ист. наук. Екатеринбург, 2000. 359 с.
} 
Thus, during the World war Ukrainian peasants in Russian army gained new socio-cultural features that contradicted their previous outlook. Obviously, not all of them became true warriors ("brave soldiers"). The long trench war, mostly, gave birth to the "grey soldier mass" that had only one aim - to survive in "bloody massacre". However, the majority of noncommissioned officers came from peasantry. They gained this title because of the personal bravery and innate wit. The future general of UPR army Mykola Kapustyanskyi characterized this category of military in the following way: "... "Khokhols", as they were called in the army, were needed in every detachment. Those were predominantly peasants, obedient, not spoiled, capable for soldiery and smart. A great percentage of them wanted to be Feldwebels and Wachmeisters" $"$

Another participant of war, and later - of revolutionary events, Nykyphir Avramenko also noted this peculiarity: "Ukrainians constituted the predominant percentage among non-commissioned officers, cavalry $i$ guard. Known by discipline and the feeling of duty..."7. We find similar characteristics in works of Oleksandr Udovychenko: "A Ukrainian soldier was always distinguished by his discipline, higher level of development and initiative. Thus, almost $40 \%$ of lower commanding positions were taken by Ukrainians, such as rojovyi (), chotovyi, bunchuzhnyi" ${ }^{8}$. Later, during revolution, these people had a special role of leaders of peasants' armed resistance.

In overall, the gained military experience facilitated the formation of the new type of peasants' consciousness - the one where the war and arms took the main place and the value of human life was significantly undermined".

\section{The beginning of revolution}

The next stage of peasantry militarization emerged on the ground of revolutionary events of 1917 . The general de-organization and demoralization of Russian army, de-sacralization of assumptions about the nature of autocratic authority and its demolition, the decline of authority of military commanding centre, the change of commanding functions by soldier committees accelerated the reformation of peasant-soldier's social role. From the sovereign of the emperor, he suddenly turned into "the master of his own destiny" who could impose his requirements not

\footnotetext{
${ }^{6}$ Капустянський М. Похід украӥнських армій на Київ-Одесу в 1919 роияі [в] Украӥна 1919 рік: М. Капустянський «Похід українських армій на Київ-Одесу в 1919 роичі». С. Маланюк «Уривки зі спогадів». Документи та матеріали. Документально-наукове видання. Київ : Темпора, 2004. С. 149.

${ }^{7}$ Авраменко Н. Спомини запорожия: Документальне видання. Київ : Темпора, 2007. С. 166.

8 Удовиченко О. Украӥна у війні за державність. Історія організації $і$ бойових дій Украӥнських збройних сил 1917-1921 рр. Вінніпег: Видав хорунжий УСС Дмитро Микитюк, 1954. С. 13.
} 
only on the former superior officers, but on any authority. As V. Lozovyi justly mentioned, the outlook and behavior of the soldier of the revolutionary period were determined by paradoxical combination of peasant values and militarized psychology of collective aggressiveness, gained during the war'.

The Ukrainization of military divisions of Russian army was also an important factor. On the one hand, this was an initiative of political activists (M. Mikhnovskyi, S. Petlura) and the engaged part of the military (activists of Pavlo Polubotok Ukrainian military club, Ukrainian military general committee, and delegates of All-Ukrainian military congresses).

On the other hand, Petrograd Temporary government and military commanding was forced to agree on the formation of Ukrainian national detachments. They were resistant to Bolshevik propaganda and ready for the call of duty. These detachments were the most effective during the military actions during the unsuccessful so-called "advance of Kerenskyi" during June-July of $1917^{10}$. The classical example of Ukrainized detachments is the $34^{\text {th }}$ army corpus under the command of P. Skoropadskyi, it was later renamed into the $1^{\text {st }}$ Ukrainian.

Undoubtedly, that the mass "Ukrainization of bugnet" facilitated the rise of national consciousness among the soldiers-peasants. At the same time, this process also increased their self-perception as of independent military force that can influence the nation-wide decision-making, especially concerning agrarian issue, important for the peasantry. Thus, the resolution of the Second All-Ukrainian military congress, where the soldiers-peasants constituted the majority of participants, supported the statements of the All-Ukrainian peasant congress on the agrarian issue. In such a way, an armed peasant became an important political factor in revolutionary events.

The all-rising revolutionary wave practically destroyed Western, Southern-Western and Romanian fronts against the countries of Quadruple Alliance. The almost chaotically demobilized at the end 1917 - at the begging of 1918 army filled the villages of Ukraine. The former soldiers became deserters; they owned an enormous quantity of weapons and military property. The peasants returned to their homes at least with guns and bullets and sometimes with machine guns and even with canons.

Apart from the "natural" self-arming, the peasants resorted to political actions. N. Makno in his memoirs described the actions of the anarchist Committee of the protection of revolution in August 1917 that

\footnotetext{
9 Лозовий В. Солдати і дестабілізація суспільно-політичного становищ а: вплив Першої світової війни на революційні процеси в Україні (1917р.). С. 23.

10 Удовиченко О. Україна у війні за державність. Історія організації $і$ бойових дій Украӥнських збройних сил 1917-1921 рр. Київ : Україна, 1993. С. 15.
} 
implemented the seizure of weapons on the territory of Huliaipilshchyna from bourgeois estates and wealthy German colonies. The future leader of the biggest peasant army stated: "Thus, the weapons were taken away from bourgeoisie and distributed among the revolutionary peasantry. The seizure was implemented calmly, without casualties"11.

Before the Zvenyhorodskyi rebellion, the weapons collected by Yu. Tiutiunnyk - the one responsible for demobilization, was distributed from warehouses to peasants. During a few days and nights the rebels secretly distributed 10 thousand of guns, 43 machine guns, 2 canons, one ironclad warship and a lot of military equipment ${ }^{12}$.

Later, a huge amount of weapons was distributed among peasants during evacuation of German and Austrian-Hungarian armies from Ukraine. Revolutionized divisions voluntarily passed the weapons to Ukrainian rebels for the permission to leave for the homeland. Those few viable German divisions that left in Ukraine were also demilitarized. Thus, in February 1919, as a result of negotiations with counter-admiral von Kessler, the German divisions of Mykolaiv transferred all its weapons to rebels of ottoman Hryhoriev ${ }^{13}$.

These conditions formed new and at the same time contradictory social roles of "an armed peasant" - one part of peasants turned into marauders, another part formed free groups of self-defense.

\section{The rebellion movement and peasant war}

The following development of revolutionary events was marked by the rebellion movement that subsequently turned into a full-scale war.

The literature on the peasant rebellion movement ${ }^{14}$ represents different characteristics of its political orientation. Sometimes they are rather simplified. For example, the Russian researcher A. Kurenyshev while pointing on the versatile nature of the Ukrainian rebels and its peculiarities in each region, he still considered that these were "the left wings of Ukrainian socialist parties" that had an important role in its organization ${ }^{15}$.

However, M. Omelyanovych-Pavlenko provided a more detailed and appropriate characteristics of the rebellion movement as he distinguished the following four political directions: supporters of UPR, "Soviets",

\footnotetext{
${ }^{11}$ Махно Н. Воспоминания. Кн. 1. Русская революциия на Украине (от марта 1917 2. по апрель 1918 год). Париж 1929. С. 70.

12 Тютюнник Ю. Революційна стихія. Дзвін. 1991. № 8. С. 101.

${ }_{13}^{13}$ Вишнівський О. Повстанський рух і Отаманія. Збірник. Дітройт; Мічіген, 1973. С. 26.

14 Історіографія питання див. : Щербатюк B.M. Селянський повстанський рух в Украӥні 1917-1921 років: українська історіографія : автореф. дис. ... д-ра іст. наук 07.00.06. Київ : Київський нац. ун-т ім. Т.Г. Шевченка, 2013. 36 с.

15 Куренышев А.А. Крестьянские военно-политические организации России. Повстанчество. 1918-1922 г2. Москва 2010. С. 41.
} 
"plowmen" and "Makhnovists" (supporters of Makhno) ${ }^{16}$. Another peculiar feature was that these political convictions of rebellion leaders were rather unstable and could change depending on the current military and political situation. Regardless this versatility and instability, the observers of that time still noticed a general tendency in the development of peasants' selfrealization that determined the political direction of the rebels. Omelyanovych-Pavlenko also noticed that "after difficult alterations of the ideology of the people in 1919, it obtained a more stable statehood form. This ideology can be described by a truly prophetical statement: "In your home you have your truth, and power, and freedom". As a result, the fight on the East turns into the national struggle more and more" ${ }^{\text {". The only }}$ precaution to the abovementioned is that different participants of the struggle understood its sense in different ways (the variety of political beliefs was rather broad - from conservative statehood idea to the leftwing anarchist denial of it).

The turning point of the development of rebellion movement was peasants' protest at times of P. Skoropadskyi's Hetmanat. M. Kapustianskyi considered the short-sighted policy in agrarian issue the main catalyst of such a reaction, especially in areas where the owners, specifically "the Polish-didychi", tried to reimburse their loss by pressuring the peasants. "The confused peasantry turned to an armed resistance and self-protection from violence. The German did not understand the situation and the free-will spirit of our Ukrainian nation and started implementing terrible repressions, contributions and torture..."18.

On the other hand, modern authors, V. Lobodaev in particular, noticed, that free Cossack communities protested against the new authority since very first days. That new authority did not have time not only to implement, but even to declare its agrarian policy. Thus, the activism of the initiators of the protest is explained by their a priori rejection of a new authority as a reactionary one. At the beginning of May 1918 community meetings of different territorial levels declared anti-Hetman stance. On May the 3 delegates of Zvenyhorod povit peasant congress supported the decision to fight against the authorities immediately ${ }^{19}$.

In a month, on July 31918 the peasants from the village Orly of Lysyany volost Zvenyhorod powiat stood up against the forces of

\footnotetext{
${ }^{16}$ Омелянович-Павленко М. Спогади командарма (1917-1920): Документально-художнє видання / Упоряд.: М. Ковальчук. Київ: Темпора, 2007. С. 282.

${ }^{17}$ Там само. С. 280.

${ }^{18}$ Капустянський М. Похід украӥнських армій на Київ-Одесу в 1919 роијі. С. 69.

19 Лободаєв В. Участь Вільного козацтва в селянському повстанському русі (травень - серпень 1918 р.). Вісник Прикарпатського університету. Історія. 2011. Вип. 20. С. 71.
} 
execution thus launching the Zvenyhorod uprising ${ }^{20}$. The crushing defeat of the force created favorable conditions for other rebellious actions. The uprising quickly spread to the neighboring Lysianka and the whole powiat. On the $5^{\text {th }}$ of July, the peasants from Moryntsi, Pedynivka, Vilshana got also engaged in a protest. The rebellious forces of 15 thousand people under Zvenyhorodka occupied the city on $9^{\text {th }}$ of July. The German divisions were defeated at Shpola, Tsvitkove and Talne.

The rebellions took place at Kaniv, Cherkasy and Tarashchan powiats. The citizens of Tarashchan established communication with several groups from Zvenyhorod, Uman, Vasylkiv, Skvyr, Kaniv and other powiats. Seeking for taking advantage, Zvenyhorod rebellion group tried to take the leadership and to lead the rebellion. However, they did not manage to do that, since the majority of peasants returned to their homes - to gather the harvest. That was another feature of the rebellion movement - local nature and dependence of the agrarian household cycle.

In July 1918 the rebels from Zvenyhorod and Tarashchan united: a new fight began. However, more outnumbering forces of the enemy made those rebels who did not surrender to retreat to the borders with Bolshevik Russia and cross the Dnipro to the left bank.

Katerynoslav region was the second area of the peasant rebellion movement in spring 1918. In May 1918 the rebels disarmed Austrian jager battalion in the village Lozovatka. The villagers from Mykhailivka, Oleksandrivka, Pokrovskyi also supported the uprising. However, the outnumbering forces of cavalry suppressed the uprising. Peasant groups under control of anarchists in Oleksandrivska region also provided an armed support to Red Army divisions that were retreating from German and UPR forces. From that time on we can observe the deployment of Makhno movement in its most massive form.

The launched peasant resistance was impossible to stop neither by local execution actions, nor by bigger repressive methods. The following escalation of revolutionary events with the constant change of geopolitical situation and the rise of warlike opposition led to the involvement of a great mass of peasants into the war actions. Firstly it was their active participation in successful battles of Directory versus Pavlo Skoropadskyi subdivisions. Later, with the further deployment of Bolshevik aggression in 1919, the appearance on the territory of Ukraine of the military forces of Antanta, the advance of Voluntary army and the armed forces of the South of Russia, the Polish armed groups, the rebellion movement became more permanent and massive.

${ }^{20}$ Щербатюк, В. М. Звенигородське збройне повстання. Краєзнавство Черкащчини. Черкаси 2005. Вип. 8. С. 136-149; Кульчицький Ю. Шаблі з плугів : Украӥнський повстанський рух у визвольних змаганнях [1917-1926 рр.]. Львів : Ін-т українознавства ім. І. Крип'якевича НАН України, 2000. 260 с. 
The peak of the deployment of the rebellion movement was in 1919 . But at the same time it acquired more destructive features. Nykyphir Avramenko mentioned: "The rebellion groups changed their National flag for a red one. "Everything is allowed!", "Rob what is already robbed!" mottos appeared to be more attractive. There were groups that seemed to stick to the national ideas, but they did not recognize any authority"... "It was a chaotic and disorganized force and it cared only about its village, volost and powiat. In the future they were all defeated. The "ottomans" did not think about what was coming next" ${ }^{21}$.

On the other hand, the power of the rebels was in this massiveness. As M. Omelyanovych-Pavlenko highlighted: "There was not a village in Ukraine that did not have its "commanding center" or a gathering point in a secret ravine or near the giant oak of "Mazepa". There they got rid of the accumulated energy at home and there the leaders-ottomans spread their opinion and will and formed the base for struggle" 22 .

The peasant rebellion movement was not limited only by revolution period, it gained momentum during Bolshevik occupation in 1920. Only concessions like NEP, Ukrainization and "exhaustion" of the peasantry resources led to the gradual suppression of rebellion in 1992-1923. The last events of the peasant war were the revolts against the compulsory collectivization and anti-peasant policy of Bolsheviks in Pavlohrad and Drabiv (1930) and the resistance against the policy of GenocideHolodomor (1932-1933).

\section{Ottoman and Makhno movements}

The phenomenon of the peasant rebellion movement cannot be understood without the analysis of such an important factor as Ottoman movement that determined the nature and essence of the peasant war. O. Vyshnivskyi divided the leaders of the rebels into two unequal groups the positive and negative (harmful) ottomans. Among the latter he mentioned the so-called "fathers-ottomans" that "either shined in glory, or were covered in shame and betrayal". As he claimed: "«Fathers-ottomans» and their groups were always labeled as adventurists and their negative actions were immediately associated with Ukrainian army and its Chief Ottoman" 23. The "spirit of the ottomania" was firstly noticed among irregular divisions of UPR army (the rebels), that joined the regular army during the uprising against Hetman Skoropadskyi. M. OmelyanovychPavlenko also noticed the emergence of ottamans-criminals that joined the

\footnotetext{
${ }^{21}$ Авраменко Н. Спомини запорожия: Документальне видання. С. 258.

${ }^{22}$ Омелянович-Павленко М. Спогади командарма (1917-1920). С. 281.

${ }^{23}$ Вишнівський О. Повстанський рух і Отаманія. Збірник. С. 10-11.
} 
trend of "organized hooliganism ... and the tendency of broader social groups, hurt by the long presence at war, for nomadic, full of everyday danger life" 24 .

Eventually, this "steppe freedom" gave birth to its most famous leader - ottoman Nestor Makhno that managed to become "the father of fathers". Peasant army of ottoman N. Makhno that was acting under mottos of non-recognition of any authority was the most powerful rebellious formation. V. Verstiuk thinks that the precise quantity of Makhno army is impossible to state.

On the peak of its activity in October-November 1919 the revolutionary rebellious army of Ukraine (supporters of Makno) possessed 40 thousand bugnets, 20 thousands of sabers, 1000 machine guns and 20 cannons - according to data of V. Bilash. Different sources and authors establish its quantity from 20 to 100 thousands soldiers ${ }^{25}$. The basis of Makhno rebellion movement was Steppe Left Bank: Katerynoslav, Kherson, Tavria powiats and the part of Donbas.

\section{The participation in regular formations}

The peasants constituted the main part of regular military formations that fought over the control on the territory of Ukraine. The majority of them were drafted. Thus, such "forced soldiers" changed armies 3-4 times ending up in some rebellious group.

The Acting Army of UPR had a typically peasant nature and it included different rebellion formations.

General M. Kapustianskyi claimed that rebellious forces of Directory in December 1918 included 300 thousand people (the number is obviously exaggerated the real number at the beginning of 1919 did not exceed 75 thousand -V.M.) mostly peasants. Though the draft was announced, the majority of peasants joined the army voluntarily as they hoped to demand the resolution of the agrarian issue. The majority of military groups emerged chaotically, "in revolutionary way". Those were weakly organized little tactical units led by almost illiterate in soldiery ottomans. In its essence it was the rebellious mass of peasants, "the most numerous elements but little reliable in struggle with Bolsheviks... The peasant uprising had mostly social reasons and only a part of it had national sentiments" 26 .

\footnotetext{
${ }^{24}$ Омелянович-Павленко М. Спогади командарма (1917-1920). С. 192.

${ }^{25}$ Верстюк В. Махновщина: Селянський повстанський рух на Украӥні (1918-1921). Київ: Наукова думка, 1991. С. 186.

${ }^{26}$ Капустянський М. Похід украӥнських армій на Київ-Одесу в 1919 роиі. С. 72-74. 
M. Omelyanovych-Pavlenko also mentions the so-called "peasant divisions" in Acting Army that were loyal only to their ottomans ${ }^{27}$. Komandarm gave a very precise characteristic for those formations. The traditional "ottoman law" based on unquestionable respect towards "single amateurs": "Just as Haidamaks, the peasant division (Kyiany (citizens of Kyiv)) was the irregular combination that only partially recognized the authority of UPR. Two months later these two groups ... engaged into a battle in the result of which one group was left with yellow-blue flag and the second one retreated already with the motto "Live the Soviet Ukraine!" to the hostile camp. This fact would be reverse for the peasant division: new elements would join it and start the transformation towards the regular division" 28 .

In April 1919 the reorganization of Acting army of UPR was implemented, in the result of which the quantity was reduced, but the combat ability increased. As M. Kapustianskyi observed, the natural selection was conducted and "All the adventurist and occasional did not bear the difficulties of the march and dispersed". "The ottomans disappeared, the groups dispersed, the drafted Cossacks (especially from the Left bank) went back home with guns, equipment and ammunition" 29 .

M. Omelyanovych-Pavlenko left interesting observations concerning the treatment of the peasantry of Uman and Cherkasy region towards the Acting armies during the first Winter march: "Our divisions always received the compassion of masses and their active help". In particular, the peasants of the village Oksanynno of Uman powiat guarded Ukrainian soldiers during the night rest and during the battle at Talne the peasants took the cannon from the enemies and delivered it on their own horses to the Ukrainian camp ${ }^{30}$.

Eventually, the commander drew a favorable conclusion: "...When the army got to the very heart of Ukraine, they saw the similarity of their ideology with the ideology of the rebels and peasant masses, they also felt that the people saw them as their weapon, apart from the name "petlurivtsi" (supporters of Petlura) they were also called "Ukrainians" and "our army"...",31.

However, Ukrainian peasants also took part in military formations that fought against Ukrainian statehood. It is important to reveal if they were in Worker-peasant Red army on the territory of Ukraine.

\footnotetext{
${ }^{27}$ Омелянович-Павленко М. Спогади командарма (1917-1920). С. 190.

28 Там само. С. 221.

${ }^{29}$ Капустянський М. Похід українських армій на Київ-Одесу в 1919 рочі. С. 90.

${ }^{30}$ Омелянович-Павленко М. Спогади командарма (1917-1920). С. 248.

31 Там само. С. 268.
} 
During the first Soviet-Ukrainian war some dismissed military divisions including Ukrainian peasants-soldiers joined the Bolshevik advance (divisions of the $7^{\text {th }}$ Army). However such participation was sporadic since the core majority of Red army consisted from ethnical Russians from other regions.

The Red Cossacks can be considered as the exception formed at the beginning of January 1918 in Kharkiv from initiative of V. Shakrai and V. Prymakov. Such a naming, as Prymakov later wrote, was accepted as an "opposition to Petlurian free Cossacks". The $1^{\text {st }}$ regiment of Red Cossacks was created on the basis of the $3 \mathrm{~d}$ battalion of the $2^{\text {nd }}$ Ukrainian spare regiment that took the side of Bolsheviks. However, the present materials testify that the majority of Red Cossacks were of worker, not peasant origin.

However, in 1919 the situation significantly changed. The occupational Red army had a peculiar hybrid content (like the modern Russian-terrorist military groups on the occupied part of Donbas). As M. Kapustianskyi: "In Soviet Ukrainian army there were the divisions formed in Ukraine and those that came from central Russia. The organization of both was not equal. During the formation of their divisions in Ukraine the Bolsheviks had to take into account the character of Ukrainian population - very active before partisan war and during operations in their groups with their ottomans" ${ }^{32}$.

The content of these Ukrainian formations was rather diverse. Among them there was the $1^{\text {st }}$ regiment of the Red Cossacks under the leadership of Vitaliy Prymakov that previously retreated to Russia, but continued to exist in the Red Army of RSFSR. Later it became the cavalry brigade, division and at the end of 1920 - the first cavalry corpse of the Red Cossacks. However, it included a lot of international groups (Hungarians, Kurds, Lithuanians, Kubans, etc). The $1^{\text {st }}$ Ukrainian Soviet army consisted from Ukrainian formations ( $1^{\text {st }}$ and $2^{\text {nd }}$ Ukrainian Soviet divisions - former "tarashchantsi" and "bozhenkivtsi"), as well as from Russian ones - the $3 \mathrm{~d}$ Border and the $9^{\text {th }}$ shooting division of RSChA.

We can judge if the ethnical content of these formally Ukrainian divisions corresponded to their naming from the memories of Vsevolod Petriv. The general-horunzhyi mentioned that $100 \%$ of Ukrainians from the Right bank and some Ukrainians from Slobidska Ukraine from "tarashchantsi" took the side of Bolsheviks.

But from reformation into the division they were joined by cannon groups of solely Russians from Saratov and Yufim govetnorates. Before the beginning of advance against the Directory citizens of Smolensk and

\footnotetext{
${ }^{32}$ Капустянський М. Похід українських армій на Київ-Одесу в 1919 роиі. С. 94.
} 
Voronezh governorate also joined them. The regiment of Zaliznyak was dismissed because of "chauvinist beliefs" and formed again on the basis of citizens from Smolensk and Volohod governorates.

"In 1919 when the Volyn group..., defeated "tarashchantsi" nearly 800 people from Bohuniv regiment and 120 from Honta regiment were captured. Bohun regiment had $40 \%$ of people that were from Tambov, $10 \%$ from Viatychi, 15\% from Moscow and 5\% were Kazan tatars, $10 \%$ were Belorusians and $20 \%$ from Slobozhanshchyna and Chernihiv regions, mostly from Starodub powiats, thus partially Russians. People from Honta regiment were from Tambov governorate"33. Thus, to establish the percentage of Ukrainian peasants in these divisions is rather difficult.

However, the rebellion formations consisted mostly from peasantry that due to different reasons left UPR army for the Red army.

At the end of December 1918, right after the victory of anti-Hetman rebellion, Dnipro division of ottoman Zelenyi (D. Terpyla) declared that it did not want to fight against the Bolsheviks Amidst the battle for Kyiv in January 1919 this division opened the front and hit the army of UPR between Kyiv and Kremenchuk, thus facilitating the occupation of the Left bank and Kyiv by Bolsheviks. Ottoman Zelenyi declared Soviet mottos and retreated to the forests of Trans-Dnipro area where he continued to implement the operations together with Bolsheviks or on their own. Only in May 1919 they recognized the authority of Directory.

One of the biggest peasant unions that took the side of Bolsheviks at the beginning of February 1919 was the 6thousand Kherson division of the Acting army of UPR under the command of Nykyphor Hryhoriev. It became the $1^{\text {st }}$ brigade of Zadniprovska Ukrainian Soviet division and then, in April 1919 it was reformatted into the $6^{\text {th }}$ Ukrainian Soviet division due to the draft in local powiats. Hryhoriev remained the commanding officer. The $1^{\text {st }}$ regiment of Red Cossacks that was in Lubny at that time joined the uprising of Hryhoriev.

However on May the $8^{\text {th }} 1919$ Hryhoriev issued Universal "To the people of Ukraine and the soldiers of Red army" where he called for the general uprising against the Bolshevik dictatorship in Ukraine and announced the goals of his struggle. He proclaimed himself as "Ottoman of partisans of Kherson and Tavria Hryhoriev". The forces of rebellion involved 15-23 thousand of combatants, predominantly the peasants. Obviously, this uprising was caused by the rise of social-political tension in the village, caused by the policy of "military communism" and the establishment of Bolshevik dictatorship. The actions of the

33 Петрів В. Військово-історичні прачі. Спомини. Збірник /вступ В. Сергійчука. Київ «Поліграфкнига», 2002. 640 с. 
rebellious divisions provoked the general peasant uprising against the Bolsheviks in Ukraine.

The issue of participation of Ukrainian peasants in formation of Military forces of the South of Russia still remains little researched. Mostly the people were drafted, but there were voluntary subdivisions, for example among the local self-defense units of the State Guard.

Apart from this, as S. Kornovenko claims, the Special council and the Government of the South of Russian led the pro-peasant agrarian policy (state protectionism of the peasantry), they cared about the improvement of the land management, increasing of technical cultivation of land, providing of land farms with equipment, seed funds, working cattle, prevented the escalation of confrontation in villages.

It could not but cause a positive treatment of peasants towards the Whites policy of normalization of rent relationships and intensification of agrarian sector as an economy branch ${ }^{34}$.

However the attempts of social consolidation were significantly undermined by the rebellion movement. M. Herasymenko noted that after the raid of Makhno army the peasant mass not only joined the opposition against the authority of Denikin, but also joined the armed struggle against $\mathrm{it}^{35}$.

\section{CONCLUSIONS}

Thus, the development of revolutionary events and the establishment of national statehood directly depended on opinions of Ukrainian peasantry and its military activity. However, the peasants as the military-political force had rather unstable convictions. As a rule, they greeted every new authority that promised to resolve the agrarian issue according to their interests, later they got disappointed in it and eventually rebelled against it.

Sociomental aspects of militarization of the peasants included the references to the "Cossack tradition" often interpreted as a "Cossack freedom". They tried to combine military craft with the traditional plowman work (at the first opportunity they returned to it). Military actions of the armed peasantry were mostly defensive (they defended their own homes). That is the source of the locality of peasant thinking, isolation of their "peasant world".

As for the military aspect, the peasants took part in voluntary formations and rebellion groups led by ottomans. The latter have special social and psychological characteristics. Not that many peasants took part

\footnotetext{
${ }^{34}$ Корновенко С.В. Аграрна політика урядів А. Денікіна та П. Врангеля (1919-1920 рр.). дис. ... д-р. іст. наук. Київ 2009. С. 389-390.

${ }^{35}$ Герасименко Н.В. Батько Махно. Мемуары белогвардейияа / Под ред. П.Е. Щеголева. Москва Ленинград: Государственное издательство, 1928.
} 
in the regular formations of peasants. Big peasant military formations were not stable. After they faced with organized resistance of the opponent, they, as a rule, dispersed into little groups and resorted to the partisan tactics of struggle.

Military peculiarities of the new revolutionary peasants correlated with their statehood principles. Their support of ottomans was caused by their reluctance to the new authority. After all, the state elements in the consciousness of the majority of peasants were rather weak.

\section{SUMMARY}

The article analyzes the peculiarities of militarization of Ukrainian peasantry as the part of its emancipation in the process of militarization. It argues about its significance during the events of the World War I. The war caused the drastic transformation of the peasant outlook that integrated the remains of the warfare.

It claims that the role, social status and behavior of the "peasant with the gun" changed with the beginning of the revolution of 1917. An armed peasant became an important political factor of the deployment of the revolutionary events. On the one hand, the important part of the peasants joined the process of the "expropriation of expropriators" - expropriation of the lands and the estate.

On the other hand, the peasant environment launched the voluntary movement of self-defense (The Free Cossacks) from internal chaos and external dangers. Eventually, the militarization of the peasantry determined its leading role in the events of Ukrainian revolution 1917-1921, including the deployment of the rebellion movement, peasant war, ottoman movement etc. The article reveals the peculiarities of the peasants' participation in military formations of the revolutionary period - the Acting army of the UPR, Worker-peasant of the Red army, The military forces of the South of Russia.

\section{REFERENCES}

1. Авраменко Н. Спомини запорожия: Документальне видання. Київ: Темпора, 2007. 456 с.

2. Верстюк В. Махновщина: Селянський повстанський рух на Україні (1918-1921). Київ: Наукова думка, 1991. 368 с.

3. Вишнівський О. Повстанський рух i Отаманія. Збірник. Дітройт; Мічіген: Капітула відзнаки хреста залізного стрільця, 1973. 109 c. 
4. Герасименко Н.В. Батько Махно. Мемуары белогвардейцуа / Под ред. П.Е. Щеголева. Москва-Ленинград: Государственное издательство, 1928. 115 с.

5. Капустянський М. Похід українських армій на Київ-Одесу в 1919 рочі [в] Украӥна 1919 рік: М. Капустянський "Похід украӥнських армій на Київ-Одесу в 1919 роиіі”. С. Маланюк "Уривки зі спогадів". Документи та матеріали. Документально-наукове видання / Передм. Я. Тинченко. Київ : Темпора, 2004. С. 59-286.

6. Корновенко С.В. Аграрна політика урядів А. Денікіна та П. Врангеля (1919-1920 рр.). Дис. ... д-p. іст. наук. Київ: Інститут історії України НАН України, 2009. 474 с.

7. Кульчицький Ю. Шаблі з плугів : Український повстанський pyx y визвольних змаганнях [1917-1926 pp.]. Львів : Ін-т українознавства ім. І. Крип'якевича НАН України, 2000. 260 с.

8. Куренышев А.А. Крестьянские военно-политические организаџии России. Повстанчество. 1918-1922 г2. Москва 2010. 171 с.

9. Лободаєв В. Участь Вільного козацтва в селянському повстанському русі (травень - серпень 1918 р.). Вісник Прикарпатського університету. Історія. 2011. Вип. 20. С. 70-78.

10. Лозовий В. Солдати і дестабілізація суспільно-політичного становищ а: вплив Першої світової війни на революційні процеси в Україні (1917р.). Вісник Київського національного університету імені Тараса Шевченка. Історія. 2014. № 3 (121). С. 21-24.

11. Махно Н. Воспоминания. Кн.1. Русская революция на Украине (от марта 1917 г. по апрель 1918 год). Париж 1929. 214 с.

12. Омелянович-Павленко М. Спогади командарма (1917-1920): Документально-художне видання / Упоряд.: М. Ковальчук. Київ: Темпора, 2007. 608 с.

13. Петрів В. Військово-історичні праиі. Спомини. Збірник / вступ В. Сергійчука. Київ : “Поліграфкнига", 2002. 640 с.

14. Поршнева О.С. Крестьяне, рабочие и солдаты России накануне и в годы Первой мировой войны. Москва : РОССПЭН, 2004. $365 \mathrm{c}$.

15. Поршнева О.С. Менталитет и сочиальное поведение рабочих, крестьян и солдат России в годы Первой мировой войны (1914 март 1918). Дисс. ... д-р ист. наук. Екатеринбург, 2000. 359 с.

16. Русское крестьянство и Первая мировая война : международный круглый стол / публ. П.П. Марчени, С.Ю. Разина. Новый исторический вестник. 2014. № 2 (40). С. 8-89.

17. Тютюнник Ю. Революційна стихія. Дзвін. 1991. № 8. C. 92-107. 
18. Удовиченко О. Україна у війні за державність. Історія організачії $і$ бойових дій Украӥнських збройних сил 1917-1921 рр. Вінніпег: Видав хорунжий УСС Дмитро Микитюк, 1954. 179 с.

19. Щербатюк В.M. Звенигородське збройне повстання. Краєзнавство Черкащини. Черкаси, 2005. Вип. 8. С. 136-149.

20. Щербатюк В.М. Селянський повстанський рух в Украйні 1917-1921 років: українська історіографія : автореф. дис. ... д-ра icm. наук 07.00.06. Київ : Київський нац. ун-т ім. Т.Г. Шевченка, $2013.36 \mathrm{c}$.

\section{Information about the author:} Masnenko V. V. Doctor of Historical Sciences, Professor, Head at the Department of History Ukraine, Bohdan Khmelnytsky National University of Cherkasy 81, T. Shevchenka str., Cherkasy, 18031, Ukraine 


\section{THE POLICE OF THE SEVERAN DYNASTY TOWARDS CHRISTIANITY}

\section{Petrechko O. M.}

\section{INTRODUCTION}

Many aspects of the reign of Emperor Septimius Severus are still controversial in the modern historiography of ancient Rome. This thesis is valid for a wide range of issues, concerning both home and foreign policy of the founder of the Severan dynasty. There is no consensus among historians on the issues of Septimius Severus's reforms and their influence on the development of the Principate system.

Edward Gibbon had no doubt that Septimius Severus was an absolute monarch whose interests coincided with that of the Roman people: "Severus considered the Roman Empire as his property, and had no sooner secured the possession than he bestowed his care on the cultivation and improvement of so valuable an acquisition". Mason Hammond was of the same opinion. In his view, Septimius Severus replaced the Principate of Augustus, in which the Senate was the nominal head and the real co-ruler of the Empire, with a military and dynastic monarchy, with total concentration of power in the hands of the ruler ${ }^{2}$. Other researchers share the same opinion ${ }^{3}$. Ivan Sergeev believes that the founder of the Severan dynasty "improved" the system of the Principate. The scientist considers Severus's military policy not as an attempt to thank the soldiers for their help in the struggle for power, but as an attempt to strengthen the position of the central government and to strengthen the loyalty of soldiers to the emperor ${ }^{4}$.

The problem of the government's policy on Christianity during the period of the Severan dynasty remains obscure. A vivid example of controversy is the Septimius Severus edict concerning the Jews and the Christians. There is no consensus on the time of its publication and the

\footnotetext{
${ }^{1}$ Gibbon E. The decline and fall of the Roman Empire. New York : Peter Fenelon Cooper, 1899. Vol. I. P. 144.

${ }^{2}$ Hammond M. Septimius Severus, Roman bureaucrat. Harvard Studies in Classical Philology. 1940. Vol. 51. P. 137.

${ }^{3}$ Fishwick D. The Imperial Cult in the Latin West : studies in the ruler cult of the western provinces of the Roman Empire. Leiden : Brill, 1987. - Vol. 1.2. P. 335.

4 Сергеев И.П. Римская империя в III веке нашей эры. Проблемы социально-политической истории. Харьков : Майдан, 1999. С. 56.
} 
influence it had on the development of Christianity ${ }^{5}$, whether this was an edict, as we also think, or a rescript ${ }^{6}$, there even have been expressed doubts regarding the very fact of the existence of this edict ${ }^{7}$. It should be noted that religious policy in fact was an important component of the Principate of Septimius Severus. The analysis of recent research and publications reveals that the problem of the relationship between Christianity and Roman authorities is largely considered in the context of the persecutions of the Christians. This seems justified, given that the study of the causes of these persecutions allows us to understand the logic of the integration of Christianity into Roman society and the evolution of its relationship with the Roman authorities. By carefully examining the legal, political and religious aspects of the attitude of the Romans towards the Christians, scientists are trying to find an acceptable solution to the problem of the persecution of the Christians ${ }^{8}$. There's a lot of talk with regard to the possibility of the existence of a general law adopted during the reign of Nero or Domitian, in force in the entire empire, prohibiting the Christianity. Proponents of the theory of coercitio believe that Christians were punished by Roman officials without resorting to special legislation, founded on their authority based on their imperium. It is also stated that the persecution of the Christians took place on the basis of existing laws against specific crimes: infanticide, incest, magic, etc. In addition, there has been expressed an opinion that the government policy on Christianity depended on the wishes and views of the incumbent emperor ${ }^{9}$. Obviously John Crake was right to call this controversy "endless" ". Adrian Sherwin-

5 Лебедев А. П. Эпоха гонений на христиан и утверждение христианства в Греко-римском мире при Константине Великом. Москва : Изд-й отдел Спасо-Преображенского Валаамского Ставропигиального монастыря, 1994. С. 231-237; Федосик В.А. Киприан и античное христианство. Минск : Университетское, 1991. С. 15; Platnauer M. The life and reign of the Emperor Lucius Septimius Severus. London : Oxford University Press, 1918. P. 154.

${ }^{6}$ Frend W.H.C. Persecutions: genesis and legacy / The Cambridge History of Christianity / Ed. by Margaret M. Mitchell \& Frances M. Young. Cambridge : Cambridge University Press, 2006. Vol. I : Origins to Constantine. P. 511; Keresztes P. The Emperor Septimius Severus : a Precursor of Decius Historia. 1970. Bd. 19, H. 5. P. 573-574; Plescia J. On the persecution of the Christians in the Roman Empire. Latomus. 1971. Fasc. 1. T. 30. P. 123.

${ }^{7}$ Крист К. История времен римских императоров от Августа до Константина : в 2-х т. Ростов н/Д. : Феникс, 1997. T. 2. С. 345; Barnes T.D. Legislation against the Christians. The Journal of Roman Studies. 1968. Vol. 58, Parts 1-2. P. 41; Suski R. Jowisz, Jahwe i Jezus : religie w Historia Augusta. Warszawa : Wydawnictwo Naukowe Sub Lupa, 2014. P. 261.

8 Janssen L.F. «Superstitio» and the Persecution of the Christians. Vigiliae Christianae. 1979. № 2, Vol. 33. Р. 131.

9 Лебедев А.П. Эпоха гонений на христиан и утверждение христианства в Греко-римском мире при Константине Великом. Москва : Изд-й отдел Спасо-Преображенского Валаамского Ставропигиального монастыря, 1994. С. 5-36; Bryan C. Render to Caesar : Jesus, the early church and the Roman superpower. Oxford : Oxford University Press, 2005. P. 116; Canfield L.H. The early persecutions of the Christians. New York : Columbia University, 1913. P. 25; Ramsay W.M. The Church in the Roman Empire. London : Hodder and Stoughton, 1893. P. 209; Sherwin-White A.N. The early persecutions and Roman law again. The Journal of Theological Studies. 1952. Vol. III, issue 2. P. 199.

${ }^{10}$ Crake J.E.A. Early Christians and Roman law. Phoenix. 1965. № 1. Vol. 19. P. 62. 
White thoroughly looked into the aforementioned theories in the appendix to his comments on the letters of Pliny the Younger ${ }^{11}$.

\section{Hostility of the Romans to the Christians and Septimius Severus}

The formation of Christianity and its early history are closely linked to ancient Rome. Christian communities arose both in Rome itself and in provincial cities; Christian texts were written in Latin and in Greek, which ensured the widest possible spread of Christian doctrine, both in the West and in the Eastern Provinces. The Roman Empire provided a broad political, social and religious environment for the emergence of early Christianity $^{12}$. Actually, Christianity transformed into a world culture phenomenon due to the realities of the existence within the Roman Empire, where religious life was not private, but a state affair. Edward Gibbon stated five causes of the rapid growth of the Christian Church:

" 1 . The inflexible, and, if we may use the expression, the intolerant zeal of the Christians, derived, it is true, from the Jewish religion, but purified from the narrow and unsocial spirit, which, instead of inviting, had deterred the Gentiles from embracing the law of Moses.

2. The doctrine of a future life, improved by every additional circumstance which could give weight and efficacy to that important truth.

3. The miraculous powers ascribed to the primitive church.

4. The pure and austere morals of the Christians.

5. The union and discipline of the Christian republic, which gradually formed an independent and increasing state in the heart of the Roman Empire" 13 .

However, the process of Christianization of the Roman Empire was complex and ambiguous. In the first three centuries the Christians were persecuted by the Roman authorities. The study of the interaction between the Christianity and the authorities is extremely important both to understand the internal policies of the Roman government and to understand the essence of Christianization. In historiography, we even can find the identification of Christianization with the process of interaction between Christianity and various secular institutions ${ }^{14}$. Ambrogio Donini

\footnotetext{
${ }^{11}$ Sherwin-White A.N. The letters of Pliny : a historical and social commentary. Oxford : Clarendon Press, 1966. P. 772-787.

${ }^{12}$ Klauck H.J. The Roman Empire / The Cambridge History of Christianity / Ed. by Margaret M. Mitchell \& Frances M. Young. Cambridge : Cambridge University Press, 2006. Vol. I : Origins to Constantine. P. 69.

${ }^{13}$ Gibbon E. The decline and fall of the Roman Empire. New York : Peter Fenelon Cooper, 1899. Vol. I. P. 505-506.

14 Казаков М.М. Проблема христианизации Римской империи. Исследования по зарубежной истории. Смоленск, 2000. С. 196-197. Режим доступа : http://ancientrome.ru/publik/article.htm?a=140 5377993.
} 
believes that Christianization of the empire was actually a merger of Christianity with the new state institutions ${ }^{15}$.

At the end of the first century $\mathrm{BC}$ necessary prerequisites for the successful establishment of Christian ideology in Roman society were formed. In this context, it should be mentioned that the Roman, who was a true follower of traditional Roman beliefs, was, more likely, ready to accept the basic postulates of the Christian religion. It was quite common to believe in the immortality of the soul ${ }^{16}$. The veneration of the souls (manes) of their ancestors was a commonplace for the Romans. The emperor, as a rule, during his lifetime was awarded the title pater patriae father of the Fatherland. Naturally, the deceased emperor had the divine honors. John Kenrick reasonably good guessed that almost the universal introduction of epitaphs Diis Manibus, or abbreviation D.M. indicated general belief that the spiritual component of human nature continues to exist after death ${ }^{17}$. There is reason to believe that in the minds of the Romans, the souls of the dead relatives became younger deities - manes. The Roman writers told about the existence of the soul after death, such information we also find on the epitaphs ${ }^{18}$. So, for the Romans, the idea of the existence of the soul after the death of the body was not new. It was new that Christianity told not only about the existence of the soul after the death of the body, but also about the salvation of the soul. However, this fact, obviously, should not have caused a negative reaction in Roman society. Not surprisingly, at the end of the second century, the number of Christians increased significantly.

There was an opinion about the tendency towards a certain religious tolerance during the reign of the Severan dynasty ${ }^{19}$. Tertullian told us about the goodwill of Septimius Severus towards Christians (Tert. ad Scap. 4). Indeed, the beginning of the reign of Septimius Severus was peaceful for Christians. They joined the ranks of the Roman military forces more actively, and even baptized Christians were enlisted in the army ${ }^{20}$. In all regions of the Roman Empire, there is a lot of evidence of the enrolment of Christians in military service, at least since the middle of the second

15 Донини А. У истоков христианства (от зарождения до Юстиниана). М. : Политиздат, 1989. С. 171.

16 Moore C.H. Pagan ideas of immortality during the Early Roman Empire. Cambridge : Harvard University Press, 1918. P. 41.

${ }_{17}$ Kenrick J. Roman sepulchral inscriptions : their relation to archaeology, language, and religion. London ; York : John Russell Smith ; R. Sunter ; H. Sotheran, 1858. P. 52.

${ }^{18}$ Petrechko O. A burial rite of the Romans in the context of the ancient society conception of the soul // Проблеми гуманітарних наук : збірник наукових пращьь Дрогобицького державного педагогічного університету ім. I. Франка. Серія «Історія». 2016. Випуск 38. Р. 246-267.

${ }^{19}$ Aubé B. Les chrétiens dans l'Empire Romain de la fin des Antonins au milieu du IIIe siècle. Paris : Didier et Cie, 1881. P. 62.

${ }^{20}$ Gero S. «Miles Gloriosus» : The Christian and military service according to Tertullian. Church History. 1970. № 3. Vol. 39. P. 291. 
century $^{21}$. This trend, in part, can be explained by the increase in the attraction of the military service due to the reforms of Septimius Severus. He increased the fee to the soldiers and, apart from other privileges, gave them the right to marry "to live with their wives" ( $\gamma v v \alpha l \xi i$ i $\tau \varepsilon$ ovvol $\chi \varepsilon \tilde{v} v)$ (Herodian 3.8.5). However, we should not exaggerate the mercantile motives in the desire of Christians to join the army. Previous increase in salaries to legionnaires was carried out by Emperor Domitian. The reform of Septimius Severus only made up for the inflation that had taken place since that time $\mathrm{e}^{22}$. In any case, there is a reason to believe that there was a tendency for more active participation of Christians in the official institutions of the Roman state, including the army.

A perceptible increase in the number of Christians inevitably increased the risk of conflict situations between them and the rest of society. This was facilitated by the intensification of factions with extremist views among the Christians, in particular, Montanists, who called themselves $\pi v \varepsilon v \mu \alpha \tau \imath \kappa o i$. These were extreme rigorists who opposed military service, urged their followers to become voluntary martyrs and did not approve of escape by flight, as opposed to the policy of the official Church. One of the follower of this faction, at a certain stage of his life, was a prominent Christian writer Tertullian. Montanists, who expressed extreme views in Christianity, gave enough reasons for association with the most dangerous forms of superstition, such as magic and divination. The typical terminology of Montanism ( $\chi \alpha \dot{\rho} \rho \iota \varsigma, \delta v ́ v \alpha \mu l \varsigma, \pi v \varepsilon \tilde{v} \mu \alpha$ ) is constantly found in magical papyri ${ }^{23}$. Among Christians there were also those, who personally engaged in magic and astrology (Tert. De idololat. 9). Legislation, however, severely punished those engaged in magic and divination. This is referred to by legal experts at the time of Severan dynasty: the soothsayers (vaticinatores), after being beaten with sticks, were expelled from the city (primum fustibus caesi civitate pelluntur). Particularly malicious ones were put into fetters or sent "to the island" (in insulam). Anyone who introduced new, unknown religious doctrines could have been exiled if he was of noble origin (honestiores) or executed if he was from commoners (humiliores) (Paulus. Sententiae. 5.21.1 - 2).

In our opinion, the hypothesis that precisely "Montanism was a prelude and cause of local persecution" 24 is sufficiently substantiated. Perhaps it was Montanists who were the catalyst for persecutions that

${ }^{21}$ Helgeland J. Christians and the Roman Army A. D. 173-337. Church History. 1974. № 2. Vol. 43. P. 156.

${ }^{22}$ Smith R.E. The army reforms of Septimius Severus. Historia. 1972. № 3. Bd. 21, H. 3. P. 492.

${ }^{23}$ Wypustek A. Magic, Montanism, Perpetua, and the Severan Persecution. Vigiliae Christianae. 1977. Vol. 51. № 3. P. 277.

${ }^{24}$ Phipps C.B. Persecution under Marcus Aurelius. An historical hypothesis. Hermathena. 1932. № 47. Vol. 22. P. 201. 
began in 197 in the Proconsul province of Africa. Paulus Orosius points out that Septimius Severus subjected Christians to the fifth, after Nero, persecution (quinta post Neronem persecutione Christianos excruciavit) and many of them suffered martyrdom (Oros. 7.17.4). Sources do not give us much information about these events. Our knowledge is based on the works of Tertullian: "To the Martyrs" (Ad martyras), "To the Nations" (Ad nationes) and "Apologeticus" (Apologeticum). All of them were written in 197, or a little later. According to the sources, those who were exposed in the practice of Christianity were thrown into jail. The prisoners were supported by the brothers in faith. Among them was Tertullian, who cheered prisoners with the words: "the prison gives the Christians what the desert gives the prophets" (Hoc praestat carcer Christiano, quod eremus prophetis). Tertullian listed "positive" sides of arrest: prisoners did not see strange gods, did not encounter their images etc. (Tert. Ad martyras. 2). The arguments cited by Tertullian should have prevented the apostasy, which was an inevitable companion for any persecution. Paul Keresztes rightly noted the anxiety of Tertullian about apostasy ${ }^{25}$.

Probably the initiator of the persecution in 197, as it often happened, was not the government, but the crowd. This is evidenced by the words of Tertullian. Shortly after the aforementioned events, he uses the phrase "an uneducated crowd" (indoctum vulgus), "a stupefied crowd" (caecum vulgus) (Tert. Apol. 22; 49). The hostility of the crowd was largely caused by the lack of reliable information about the essence of Christian doctrine and the distorted perceptions of the relationship between Christians. Tertullian says: "Some of you have dreamed that the donkey's head is our god" (Nam et, ut quidam, somniastis caput asininum esse deum nostrum) (Tert. Apol. 1). But if such concoction, as well as rumors of Thyestean feasts and Oedipal relations between Christians, had no real basis, the denial of the traditional gods was a reality. And it required a proper reaction from the rulers. Roman religion did not envisage the ban of other cults. Starting under the Flavian dynasty, the Roman coins testify the emergence of eastern cults that get an official status. But even under the Severan dynasty, which was favorable towards the Eastern cults, coins are devoted mainly to Roman gods ${ }^{26}$. The Romans perceived their religion as part of the state system. During the Principate period, emperors relied on traditional Roman religion and imperial cult. Therefore, the fact that Christians neglected traditional Roman religion was perceived as an encroachment on the basis of a state organization.

${ }^{25}$ Keresztes P. The Emperor Septimius Severus : a Precursor of Decius Historia. 1970. Bd. 19, H. 5.

${ }^{26}$ Абрамзон М.Г. Монеты как средство пропаганды официальной политики Римской империи. Москва : Институт археологии Российской Академии наук, 1995. С. 421-430. 
Another aspect of the conflict between Rome and Christians was the disrespect of the latter to the ancestral custom - mos maiorum (as it was treated by the Romans). In Rome, the observance of ancient customs was considered to be an inherent part of the duties of each individual citizen and the community as a whole. The introduction of the Principate was accompanied by a struggle for the revival of ancient traditions, which was supposed to reduce foreign influences. At the same time, the Romans endorsed the respect for strict adherence to tradition by other peoples, as can be seen from the example of the assessment given by Valerius Maximus to Massilians: "Inde Massilienses quoque ad hoc tempus usurpant disciplinae gravitatem, prisci moris observantia, caritate populi Romani praecipue conspicui" (also Massilians in terms of careful observance of obligations, following the customs of their ancestors, remarkably remind the Roman people) (Val. Max. 2.6.7). Therefore, it is not surprising that those emperors who took the greatest care of the interests of the state persecuted Christians the most consistently, and those are, Trajan and Marcus Aurelius. Leaving the activities of Christians without proper reaction meant to encourage them and others to neglect their duties towards the state. Joseph Plescia believes it should be spoken not of the struggle between Christians and pagans, but between Christianity and Romanitas, i.e. "the Roman way of life" 27 . There were other factors that caused hostility towards Christians, in particular, the presence of a large number of foreigners, who came from the eastern provinces, in the Christian communities. Negative reaction was also caused by the attempts of Christians to dissociate themselves from all others in a society where the life of a private person was traditionally public. Of all the "superstitions" of that time only Christianity preached an idea about its own exclusiveness $^{28}[3,90]$. Thus, the first persecution of Christians during the reign of the Severan dynasty, which took place in Africa in 197, was limited in scope and was probably committed on the initiative of the crowd.

\section{The second persecution of Christians under Septimius Severus and Alexander Severus's attitude towards the Christians}

According to Eusebius, in the tenth year of the reign of Septimius

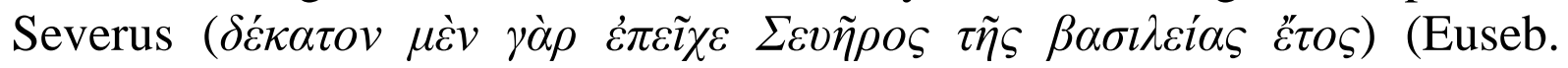
Hist. eccl. 6.2), i.e. 203, began the second persecution of Christians, which

27 Plescia J. On the persecution of the Christians in the Roman. Latomus. 1971. Fasc. 1. T. 30. P. 121-123.

28 Амосова Е.В. Спонтанные гонения на христиан как проявление кризиса античного массового сознания. Античный мир и археология. 1999. Вып. 10. С. 90. 
lasted for several years. We have a lot more information about these events. The most important sources are "Ecclesiastical history" (Historia Ecclesiastica) by Eusebius of Caesarea; biography of Septimius Severus (Vita Severi), written by Aelius Spartianus; and the Martyrdom of Saints Perpetua and Felicitas (Passio Perpetuae et Felicitatis), which is some kind of report on the suffering and death of Christian martyrs ${ }^{29}$.

The catalyst for this persecution of Christians was the edict of Septimius Severus against the Jews and Christians (201-202). According to the testimony of Aelius Spartianus, the emperor, under the penalty of punishment, forbade to convert people to Judaism (Iudaeos fieri), he also declared the same punishment for Christians (Idem etiam de Christianis sanxit) (HA. Sev. 17.1). This testimony of Aelius Spartianus forces to reject Paul Allard's assumption that the prohibition of Septimius Severus meant only the material act of circumcision. Neither can one support the assertion that Septimius Severus tried to persecute only individual Christians, and not Christianity as a whole ${ }^{30}$. Apparently, Joseph Plescia is right, arguing that this edict "was directed against Christianity, not against the Chrisitians" "31. Aleksej Lebedev rightly considers this edict as an attempt by the government to put an end to the propaganda of Christianity without encroaching on the rights of Christians. Thus, Christianity was to a certain extent recognized as an authorized religion. The law rather protected the status quo of pagan religion, especially the Roman one, than attacked religions that contradicted the dominant cult ${ }^{32}$. Andrzej Wypustek allows for the possibility that the key to understanding the edict of Septimius Severus must be sought first of all in the struggle against magic and divination. The researcher believes that this was the basis for the behavior of Septimius Severus and his officials ${ }^{33}$.

The peculiarity of this wave of persecution was that they probably occurred throughout the Empire, or, as Paulus Orosius said, in different provinces (per diversas provincias) (Oros. 7.17.4), and among numerous martyrs there were many neophytes. According to Eusebius, a particularly large number of martyrs were in Alexandria, where they were brought from all over Egypt. Among the executed in Alexandria was Leonidas,

${ }^{29}$ Robinson J.A. The Passion of S. Perpetua. Newly edited from the MSS. with an introduction and notes; together with an appendix containing the original Latin text of the Scillitan martyrdom. Cambridge : The University Press, 1891. P. 60-95.

30 Аллар П. Христианство и Римская империя от Нерона до Феодосия. Санкт-Петербург : Синоид. Тип., 1898. С. $71-74$.

${ }^{31}$ Plescia J. On the persecution of the Christians in the Roman. Latomus. 1971. Fasc. 1. T. 30. P. 124.

32 Лебедев А.П. Эпоха гонений на христиан и утверждение христианства в Греко-римском мире при Константине Великом. Москва : Изд-й отдел Спасо-Преображенского Валаамского Ставропигиального монастыря, 1994. С. 228-231.

33 Wypustek A. Magic, Montanism, Perpetua, and the Severan Persecution / A. Wypustek. Vigiliae Christianae. 1977. Vol. 51. № 3. P. 285. 


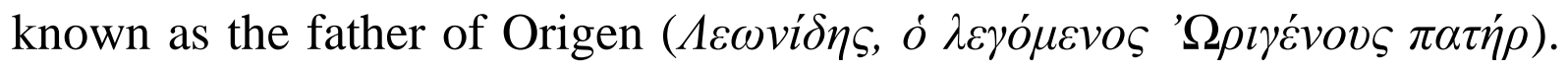
Another distinguishing feature of the persecution of 203 was that its initiative came from the emperor, as the Eusebius clearly says that it was Severus who began to persecute the churches: " $\Omega_{\varsigma} \delta \dot{\varepsilon} \kappa \alpha i ̀ ~ \Sigma \varepsilon v \tilde{\eta} \rho o \varsigma \delta \imath \omega \gamma \mu \grave{\nu} v$ $\kappa \alpha \tau \grave{\alpha} \tau \tilde{\omega} v \dot{\varepsilon} \kappa \kappa \lambda \eta \sigma i \tilde{\omega} v$ Ékivel" (Euseb. Hist. eccl. 6.1.1). Of course, the emperor did not prepare the decrees (constitutiones principium) personally. Such issues were dealt with by the personal secretary of the emperor $a b$ epistulis. The department headed by him practically managed the entire administration: it prepared instructions for officials, rescript and edicts that were issued on behalf of the emperor and sent throughout the entire Empire (magnum late dimittere in orbem Romulei mandata ducis), controlled troops and state borders (viresque modosque imperii tractare manu) (Stat. Silv. 5.1.86-88).

The fact that the edict of Septimius Severus mentioned simultaneously Jews and Christians testifies to the fact that at that time Christians were regarded as being related to the Jews. However, it was at that time that the percentage of non-Jews increased among newly converted Christians. Apparently, the number of Christians from the Gentiles surpassed the number of Christians from the Jews around the middle of the $2^{\text {nd }}$ century. Saint Justin, who wrote the first Apology during the reign of Antoninus Pius, claimed that the Christians of the Gentiles were more numerous ( $\pi \lambda$ ciovós) than the Christians of the Jews and Samaritans (Justin. Apol. 1.53.3). At that time, Latin became the language of the Western Church ${ }^{34}$. The Jews were particularly in disgrace with Septimius Severus because of the uprising that they had attempted to raise shortly after his rise to power (HA. Sev. 16.7; Oros. 7.17.3). But one may agree that it was the Christians who were the main target of Septimius Severus's decree ${ }^{35}$. This is confirmed by Eusebius's testimony that during the persecution there were cases of conversion of Christians to Judaism (Euseb. Hist. eccl. 6.12). This edict was the last act of the Roman government, directed against the Jews and the Christians at the same time.

Thus, increasing the share of non-Jews in newly converted Christians could be another motive for Septimius Severus's decree against Christians. Saints Felicitas and Perpetua, probably, took a martyr's death at the Carthage amphitheater on March 7, 203, although the date is debatable, it might have been year 202 or $204^{36}$. Saint Perpetua recorded herself

${ }^{34}$ Dudley D. The civilization of Roma. New York : New American Library; London : New English Library, 1962. P. 234.

${ }^{35}$ Frend W.H.C. Persecutions: genesis and legacy / The Cambridge History of Christianity / Ed. by Margaret M. Mitchell \& Frances M. Young. Cambridge : Cambridge University Press, 2006. Vol. I : Origins to Constantine. P. 511.

${ }^{36}$ Clarke G. Third-century Christianity / Cambridge Ancient History, $2^{\text {nd }}$ ed. Cambridge : Cambridge University Press, 2005. Vol. XII. P. 618. 
everything that happened to her, up till the moment of her martyr's death. Subsequently, these records were edited and published, perhaps by Tertullian $^{37}$. Saint Perpetua, like many other martyrs, had to endure not only the physical pain, but also the moral one. After all, by her martyrdom, she inflicted a terrible blow on her parents who did not share her desire for martyrdom. Thus, she deprived herself of the opportunity to see her newborn son grow. Saint Perpetua's father, until the last minute, in vain persuaded his beloved daughter to retreat and save her life (Passio S. Perpetuae 2). Father's visit to the imprisoned showed that Saint Perpetua belonged to two different worlds. Although the Christian community was more important for her, she was still in another world - her family's one ${ }^{38}$.

The decree of Septimius Severus did not change the legal status of Christians. Christianity remained a forbidden religion; its followers were to be executed. But officially searched for and executed were only neophytes. Paul Keresztes rightly points out that the edict of Septimius Severus led to a single real, but really important, change. Unlike Trajan's prohibition to hunt for Christians: Conquirendi non sunt (Plin. Ep. 10.97), Septimius Severus authorized the search of proselytes. Although now the authorities did not have to wait for denunciations, the search for neophytes, as the historian correctly observed, depended on the initiative of the provincial authorities ${ }^{39}$.

Tertullian gives examples of the brutal persecution of Christians by the provincial administration, as well as of sympathetic attitude towards them (Tert. ad Scap. 3-5). At the same time, it should be kept in mind that there were the persecutions of Christians, which would have taken place without the edict of Septimius Severus, as they had happened earlier, and could have continued and probably did continue.

If Septimius Severus's tolerance to Christians gives rise to serious doubts, then the attitude of another representative of the same dynasty, Alexander Severus, may be determined with a greater degree of certainty. Like Antoninus Pius, he was called "pious" (pius) and "virtuous" (sanctus) (HA. Alex. Sev. 4.5). Aelius Lampridius states that, in the morning Alexander made oblations (rem divinam faciebat) in the lararium (in larario). There were the images of the ancestors at his lararium, the very

\footnotetext{
${ }^{37}$ Robinson J.A. The Passion of S. Perpetua. Newly edited from the MSS. with an introduction and notes; together with an appendix containing the original Latin text of the Scillitan martyrdom. Cambridge : The University Press, 1891. P. $56-57$.

${ }^{38}$ Van Den Eynde S. "A Testimony to the Non-Believers, A Blessing to the Believers". The Passio Perpetuae and the Construction of a Christian Identity / More than a memory : the discourse of martyrdom and the construction of Christian identity in the history of Christianity / Ed. By Johan Leemans. Leuven : Peeters, 2005. P. 43.

${ }^{39}$ Keresztes P. The Emperor Septimius Severus : a Precursor of Decius. Historia. 1970. Bd. 19, H. 5. P. 573, 577-578.
} 
best ones, chosen (optimos electos) deified principes, as well as of some just people. Among those the historian names Apollonius, Abraham, Orpheus and Christ (HA. Alex. Sev. 29.2). There is no sufficient reason to object strongly the statement about the image of Christ. It echoes the information about Alexader's tolerance towards Christians, about his plan to build a temple for Christ and the support of Christians in the conflict regarding the land plot with the innkeepers (popinarii) (HA. Alex. Sev. 22.4; 43.6; 49.6).

Perhaps something from the reports of Alexander Severus's attachment to Christians is not true. Doubtful is the story that he gave a command to write in the Palatine palace an utterance from the Gospel, which he heard from some of the Jews or Christians: "What you do not wish that a man should do to you, do not do to him" (Quod tibi fieri non vis, alteri ne feceris) (HA. Alex. Sev. 51.8). However, the tolerant attitude of this emperor to Christians is certainly undoubted. As Eusebius renders, Julia Mammea, the mother of Alexander Severus, was not only versed in Christian doctrine, she also met with Origen, a well-known Christian writer

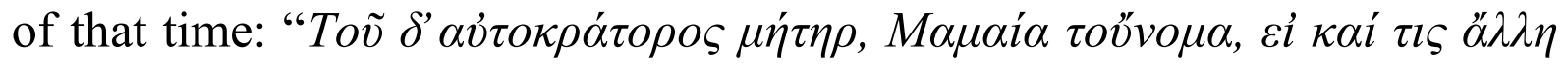

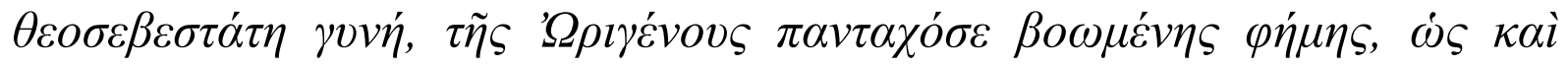

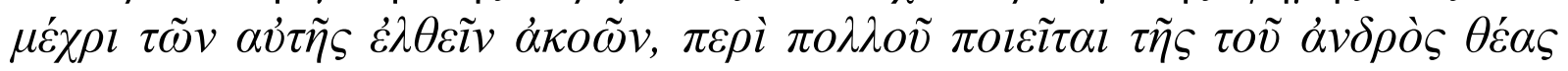

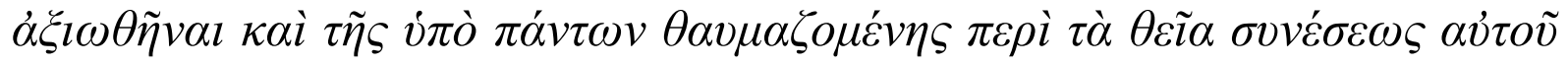

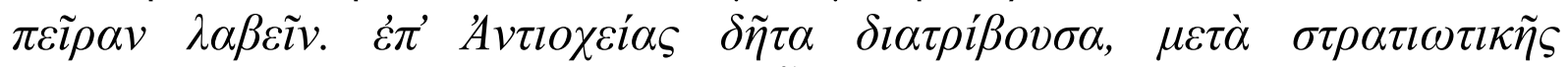

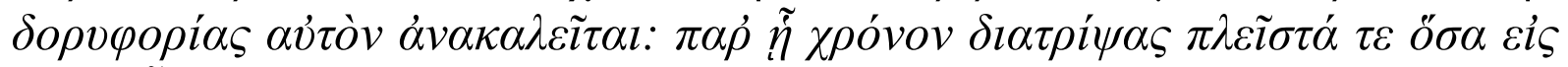

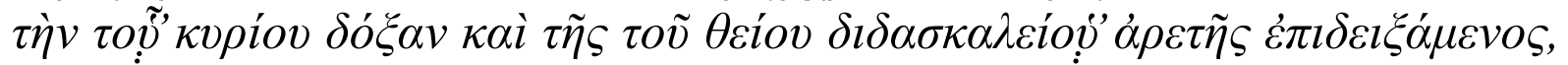

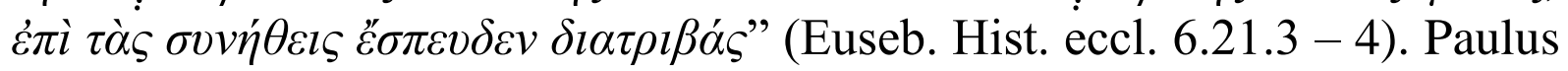
Orosius even calls her a Christian (Oros. 7.18.7). It must be recognized that the emperor was under the strong influence of his mother (Eutr. 8.23). But the reign of Alexander Severus did not bring any improvement to the legal status of Christians.

In the conflict between the Empire and Christianity, one of the parties was to be destroyed or to give something in. According to Borys Łapicki, Christians settled for a compromise, the essence of which was formulated by Apostle Paul ${ }^{40}$. In his epistle to the Romans, which can be dated year $59^{41}$, he noted: "Any soul $\left(\pi \check{\alpha} \sigma \alpha \psi v \chi \chi^{\prime}\right)$ let it be submissive to the supreme authority ... not only because of the fear of punishment, but also

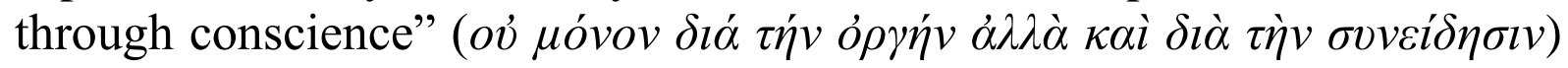
(Paul. Romans 13.1; 5).

${ }^{40}$ Łapicki B. Etyczna kultura Starożytnego Rzymu a wczesne chrześcijaństwo. Łódź : Zakład Narodowy im. Ossolińskich we Wrocławiu, 1958. S. 290.

${ }^{41}$ Толковая Библия. Петербургъ : приложение къ журналу «Странникъ», 1912. Т. 10. С. 391. 
In the First Epistle of Paul to Timothy he emphasizes that we must pray for the kings ( $\dot{v} \pi \varepsilon \rho \beta \alpha \sigma i \lambda \varepsilon \omega v$ ) and all who are in power (Paul. 1 Tm. 2.1 - 2). Tertullian notes: "A Christian knows that the emperor is set up by his God (sciens a Deo suo constitui) and one must love, fear and respect Him, and wish Him prosperity along with the welfare of the entire Roman Empire". Therefore, says Tertullian, "we make oblations for the health of the emperor, but to our God (Itaque et sacrificamus pro salute imperatoris, sed Deo nostro) and we pray for the health of the emperor (oramus pro salute imperatoris)" (Tert. Ad Scapul. 2.6; 8 -9). It is this very practice that contributed to the fact that in the relations between Christians and authorities in the second - third centuries there were long non-conflict periods. During centuries, the confrontation between Rome and Christianity only rarely reached a high level ${ }^{42}$.

\section{CONCLUSIONS}

In sum, we shall state the following: at the end of the first century BC necessary prerequisites for the successful establishment of Christian ideology in Roman society were formed. In this context, it should be mentioned that the Roman, who was a true follower of traditional Roman beliefs, was, more likely, ready to accept the basic postulates of the Christian religion. For the Romans, the idea of the existence of the soul after the death of the body was not new. It was new that Christianity told not only about the existence of the soul after the death of the body, but also about the salvation of the soul. However, this fact, obviously, should not have caused a negative reaction in Roman society. Not surprisingly, at the end of the second century, the number of Christians increased significantly. It increased the risk of conflict situations between them and the rest of society. This was facilitated by the intensification among the Christians of factions with extremist views, in particular, Montanists.

Under the Severan dynasty the legal status of Christians, in general, has not changed. Christianity remained a forbidden religion. The persecution of Christians in 197 was limited in scope and was probably based on the initiative of the crowd. The catalyst of the persecutions in 203 was the edict of Septimius Severus, which forbade the conversion to Judaism and Christianity, but was directed primarily against Christians. The main reasons for the publication of this edict were probably: firstly $-\mathrm{a}$ sharp increase in the number of Christians and activation among them of the supporters of Montanism; secondly - the growth of the proportion of non-Jews among the proselytes; and thirdly - the identification of

${ }^{42}$ Bryan C. Render to Caesar : Jesus, the early church and the Roman superpower. Oxford : Oxford University Press, 2005. P. 115. 
Christians as proponents of magic and divination. The duration and intensity of persecution was uneven in different provinces. The tolerant attitude of Alexander Severus to Christians should not be questioned, but his reign did not bring any improvement to the legal status of Christians.

From the second half of the $2^{\text {nd }}$ century AD one can speak of an increase among Christians of the spirits for more active participation in the official institutions of the Roman state, including the army. We can state that Christians came to a compromise with the Roman government. It is this very practice that contributed to the fact that in the relations between Christians and authorities in the $2^{\text {nd }}-3^{\text {rd }}$ centuries there were long nonconflict periods.

\section{SUMMARY}

The article deals with the policy of the Severan dynasty toward Christianity. It has been determined that under the Severan dynasty the legal status of Christians, in general, has not changed. Christianity remained a forbidden religion. It has been proven that the catalyst of the persecutions in 203 was the edict of Septimius Severus, which forbade the conversion to Judaism and Christianity, but was directed primarily against Christians. The main reasons for the publication of this edict were probably: firstly - a sharp increase in the number of Christians and activation among them of the supporters of Montanism; secondly - the growth of the proportion of non-Jews among the proselytes; and thirdly the identification of Christians as proponents of magic and divination. From the second half of the $2^{\text {nd }}$ century one can speak of an increase among Christians of the spirits for more active participation in the official institutions of the Roman state, including the army. It is asserted that Christians came to a compromise with the Roman government. It is this very practice that contributed to the fact that in the relations between Christians and authorities in the $2^{\text {nd }}-3^{\text {rd }}$ centuries there were long nonconflict periods.

\section{REFERENCES}

1. Aubé B. Les chrétiens dans l'Empire Romain de la fin des Antonins au milieu du IIIe siècle. Paris : Didier et Cie, 1881. vi, 530 p.

2. Barnes T.D. Legislation against the Christians. The Journal of Roman Studies. 1968. Vol. 58, Parts 1-2. P. 32-50.

3. Bryan C. Render to Caesar : Jesus, the early church and the Roman superpower. Oxford : Oxford University Press, 2005. xii, 185 p.

4. Canfield L.H. The early persecutions of the Christians. New York : Columbia University, 1913. 215 p. 
5. Clarke G. Third-century Christianity / Cambridge Ancient History, $2^{\text {nd }}$ ed. Cambridge : Cambridge University Press, 2005. Vol. XII. P. 589-672.

6. Crake J.E.A. Early Christians and Roman law. Phoenix. 1965. № 1. Vol. 19. P. 61-70.

7. Dudley D. The civilization of Roma. New York : New American Library; London : New English Library, 1962. 256 p.

8. Fishwick D. The Imperial Cult in the Latin West : studies in the ruler cult of the western provinces of the Roman Empire. Leiden : Brill, 1987. Vol. 1.2. vii, 195-371 p.

9. Frend W.H.C. Persecutions: genesis and legacy / The Cambridge History of Christianity / Ed. by Margaret M. Mitchell \& Frances M. Young. Cambridge : Cambridge University Press, 2006. Vol. I : Origins to Constantine. P. 503-523.

10. Gero S. "Miles Gloriosus": The Christian and military service according to Tertullian. Church History. 1970. № 3. Vol. 39. P. 285-298.

11. Gibbon E. The decline and fall of the Roman Empire. New York : Peter Fenelon Cooper, 1899. Vol. I. 590 p.

12. Janssen L.F. "Superstitio" and the Persecution of the Christians. Vigiliae Christianae. 1979. № 2, Vol. 33. P. 131-159.

13. Hammond M. Septimius Severus, Roman bureaucrat. Harvard Studies in Classical Philology. 1940. Vol. 51. P. 137-173.

14. Helgeland J. Christians and the Roman Army A.D. 173-337. Church History. 1974. № 2. Vol. 43. P. 149-163.

15. Kenrick J. Roman sepulchral inscriptions : their relation to archaeology, language, and religion. London ; York : John Russell Smith ; R. Sunter ; H. Sotheran, 1858. viii, 70 p.

16. Keresztes P. The Emperor Septimius Severus : a Precursor of Decius. Historia. 1970. Bd. 19, H. 5. P. 565-578.

17. Klauck H.J. The Roman Empire / The Cambridge History of Christianity / Ed. by Margaret M. Mitchell \& Frances M. Young. Cambridge : Cambridge University Press, 2006. Vol. I : Origins to Constantine. P. 69-83.

18. Łapicki B. Etyczna kultura Starożytnego Rzymu a wczesne chrześcijaństwo. Łódź : Zakład Narodowy im. Ossolińskich we Wrocławiu, 1958. $322 \mathrm{~s}$.

19. Moore C.H. Pagan ideas of immortality during the Early Roman Empire. Cambridge : Harvard University Press, 1918. 64 p.

20. Petrechko O. A burial rite of the Romans in the context of the ancient society conception of the soul // Проблеми гуманітарних наук : збірник 
наукових прачь Дрогобицького державного педагогічного університету ім. I. Франка. Серія “Історія”. 2016. Випуск 38. Р. 246-267.

21. Phipps C.B. Persecution under Marcus Aurelius. An historical hypothesis. Hermathena. 1932. № 47. Vol. 22. P. 167-201.

22. Plescia J. On the persecution of the Christians in the Roman. Latomus. 1971. Fasc. 1. T. 30. P. 120-132.

23. Ramsay W.M. The Church in the Roman Empire. London : Hodder and Stoughton, 1893. xvi, 494 p.

24. Robinson J.A. The Passion of S. Perpetua. Newly edited from the MSS. with an introduction and notes; together with an appendix containing the original Latin text of the Scillitan martyrdom. Cambridge : The University Press, 1891. viii, 131 p.

25. Sherwin-White A.N. The early persecutions and Roman law again. The Journal of Theological Studies. 1952. Vol. III, issue 2. P. 199-213.

26. Sherwin-White A.N. The letters of Pliny : a historical and social commentary. Oxford : Clarendon Press, 1966. xv, 805 p.

27. Smith R.E. The army reforms of Septimius Severus. Historia. 1972. № 3. Bd. 21, H. 3. P. 481-500.

28. Suski R. Jowisz, Jahwe i Jezus : religie w Historia Augusta. Warszawa : Wydawnictwo Naukowe Sub Lupa, 2014. 472 s.

29. Van Den Eynde S. "A Testimony to the Non-Believers, A Blessing to the Believers". The Passio Perpetuae and the Construction of a Christian Identity / More than a memory : the discourse of martyrdom and the construction of Christian identity in the history of Christianity / Ed. By Johan Leemans. Leuven : Peeters, 2005. P. 23-44.

30. Wypustek A. Magic, Montanism, Perpetua, and the Severan Persecution / A. Wypustek. Vigiliae Christianae. 1977. Vol. 51. № 3. P. 276-297.

31. Абрамзон М.Г. Монеты как средство пропаганды официальной политики Римской империи. Москва : Институт археологии Российской Академии наук, 1995. 656 с.

32. Аллар П. Христианство и Римская империя от Нерона до Феодосия. Санкт-Петербург : Синоид. Тип., 1898. vi, 292 с.

33. Амосова Е.В. Спонтанные гонения на христиан как проявление кризиса античного массового сознания. Античный мир $и$ археология. 1999. Вып. 10. С. 88-97.

34. Донини А. У истоков христианства (от зарождения до Юстиниана). М. : Политиздат, 1989. 365 с.

35. Казаков М.М. Проблема христианизации Римской империи. Исследования по зарубежной истории. Смоленск, 2000. С. 196-204. Режим доступа : http://ancientrome.ru/publik/article. htm?a=1405377993. 
36. Крист К. История времен римских императоров от Августа до Константина : в 2-х т. Ростов н/Д. : Феникс, 1997. Т. 2. 509 с.

37. Лебедев А.П. Эпоха гонений на христиан и утверждение христианства в Греко-римском мире при Константине Великом. Москва : Изд-й отдел Спасо-Преображенского Валаамского Ставропигиального монастыря, 1994. 400 с.

38. Сергеев И. П. Римская империя в III веке нашей эры. Проблемы социально-политической истории. Харьков : Майдан, 1999. $224 \mathrm{c}$.

39. Толковая Библия. Петербургъ : приложение къ журналу “Странникъ”, 1912. Т. 10.519 с.

40. Федосик В.А. Киприан и античное христианство. Минск : Университетское, 1991. 208 с.

Information about the author: Petrechko O. M.

Doctor of Sciences in History, Professor, Head of the World History and Special Historical Disciplines Department, Drohobych Ivan Franko State Pedagogical University 24, Ivan Franko str., Drohobych, 82100, Ukraine 


\section{UKRAINIAN-POLISH POLITICAL RELATIONS IN THE CONTEXT OF OPPOSING IMPERIAL ENCROACHMENTS FROM RUSSIA}

\section{Sytnyk O. M.}

\section{INTRODUCTION}

History has the property of teaching. Educate people, societies, nations, and even nations. And if this science is ignored, the reckoning is too harsh. Unfortunately, there are a lot of examples of this in the historical development of mankind. For Ukraine and Poland, starting in the second half of the XVIIIth century, history prepared a series of cruel trials that continue to this day. Starting from the deprivation of statehood of both our countries by the Moscow-Kremlin regime, tearing their territory apart, destroying the national and spiritual elite and ending with hybrid zombies, the goal of which is to deform the consciousness of Ukrainians and Poles.

\section{Historical review of Ukrainian-Polish political relations in terms of opposing imperial encroachments by Russia}

Even in the beginning of the twentieth century, Ivan Franko, with deep knowledge of the whole range of problems of Ukrainian-Polish relations, came to the paradoxical conclusion that there are no two peoples in the entire Slavic world, from the point of view of political and spiritual life, they are so much fused together and were so closely interconnected, and at the same time, they avoided each other as much as Ukrainians and Poles. At that time, Ukrainians and Poles were, in general, in the same "starting" political conditions of the absence of national statehood, with $80 \%$ of Ukrainian and more than $55 \%$ of Poles being subjects of the Romanov empire, $20 \%$ of Ukrainian and $25 \%$ of Poles being Habsburg empires, the rest of the Poles inhabiting the Hohenzollern possessions. But even with such seemingly bleak prospects, the views of most Polish politicians were based on the conviction that it was necessary to revive the Polish-Lithuanian Commonwealth in its historical ("Jagiellonian") borders, where Ukrainian lands (at least right-bank) would be an organic component of the future republic. One of the most popular concepts was formulated by the leader of the National Democratic Party G. Dmovsky ${ }^{1}$.

1 Головченко В. Українсько-польські відносини: формування міждержавних взаємин у дусі Євроатлантичного партнерства. WISŁA I DNIEPREM/НАД ВICЛOЮ I ДНIПРОМ. Торунь-Київ: Міжнародний науково-освітній консоричум імені Люсьєна Февра, 2017. Т. 1. С. 43. 
Which the main driving force of national development was considered rational to fight for their rights, religion and cultural development of the poles. Moreover, leading tool was considered not armed struggle, and the gradual cultural development of the Polish nation.

History also tends to repeat itself. Especially in cases where a particular people or nation does not make proper conclusions regarding errors and omissions. This is primarily related to the national liberation struggle of 1917-1921 years, when, being in a kind of bifurcation point, after centuries of statelessness, which was simultaneously the consequence and the cause of disintegration of the Ukrainian nation, Ukraine had a unique chance of independence. However, a number of objective and subjective circumstances, that Ukrainians could not be reached. How dare you the terror, starvation and the total destruction of Moscow occupiers, the most conscious representatives of the Ukrainian nation, including modern aggression.

Y. Dashkevich noted that Ukraine today has become a testing ground for the implementation of others, also very bloody and paid for by the loss of the national independence, ideological constructions. This was highlighted in 1917-1921 and subsequent years ${ }^{2}$. First, socialist ideas, and later the Bolshevik ideology leveled almost everything national-spiritual in Ukraine, which was not destroyed for centuries by the Russian autocracy. The policy of the Russian authorities regarding Poland was similar. Moreover, Russia was especially active in terms of using the principle of "divide and conquer". For centuries, the Russian autocratic, and then the Bolshevik authorities, used against the neighboring peoples suppressed by it a whole complex of methods and means, which are now called the "hybrid war".

The Bolshevik revolution of 1917 and the formation of the RSFSR added arguments to the Polish national democrats. Upgrading an idea antemurale (Poland is an outpost of Western Christianity in its confrontation with the East), supporters of $R$. Dmowski began to see in their activities an important mission in protecting Western civilization from the threat of exporting a "world revolution" from Moscow ${ }^{3}$. Thus, in the political doctrines of one of the most influential political forces of Polish society in the first half of the twentieth century - national democracy - there was no place for independent Ukraine, because, in their opinion, Ukraine would pursue a German policy towards the threat of

\footnotetext{
2 Дашкевич Я. Україна у вогні ідеологій. Кісь Р. Фінал Третього Риму (Російська ідея на зламі тисячоліть). Львів: Вид-во отців Василіян «Місіонер», 1998. С. IV.

${ }^{3}$ Tomaszewski J. Kresy Wschodnie w polskiej mysli politycznej XIX i XX w. Miedzy Polska etniczna a historyczna. Polska mysl polityczna XIX i XX wieku. T. 6. Warszawa, 1988. S. 171-172.
} 
Russian imperialism. No less influential and popular than the "incorporation concept" of national democrats was the "federalist program" of the "head of state" in 1918-1922 and the actual leader of the "reorganization" regime of 1926-1935, Y. Pilsudsky. He defended the idea of forming a federation of Poland with Ukraine, Belarus and Lithuania liberated from Russian rule. This would lead to the formation of a geopolitical "corridor", which was supposed to protect the Second PolishLithuanian Commonwealth from direct aggression from the "red" or "white" Russia (if the latter won the Civil War of 1918-1920). At the same time, in Poland, again, the Kholmshchina, Western Volhynia along the r. Styr and Lviv region. In the rest of Eastern Galicia and in Volhynia, it was proposed to grant the Polish minority national-cultural autonomy as part of the Ukrainian People's Republic (UNR). In the era of the Ukrainian Revolution of 1917-1920, Ukrainian-Polish relations first received models of modern interstate relations with all the relying attributes on relatively equal subjects of international law. As for the Western Ukrainian People's Republic, occupied by the newly emerged Polish state during the Ukrainian-Polish war of 1918-1919, the Poles, unfortunately, could not see in the patriotic upsurge of the national liberation struggle of the UkrainianGalicians, the desire to create their own state, that is, the phenomenon close to the Polish revival. For them, it was a leash of an anti-Polish speech that occurred on the originally (as they thought) ethnically and culturally Polish lands and which threatened the territorial integrity of the revived Polish-Lithuanian Commonwealth. The Polish side could not allow the formation of an independent Ukrainian state in Eastern Galicia, and in this all the political forces of Polish society were united. The situation was different with the Dnieper Ukraine, because from the geopolitical and military-strategic point of view, the UPR was objectively interested in establishing allied relations with the Second Polish-Lithuanian Commonwealth. According to V. Golovchenko, the result of the "Kiev campaign" by Y. Pilsudsky was the implementation not so much of his federalist program as the concept of national democrats. In the interwar period, the problem of the attitude towards the Ukrainians who became part of Poland as a result of the occupation of the Western Ukrainian lands came to the fore for Warsaw, and the strategy of assimilating them was adopted 4 . "Poland for the Poles" - this is how you can briefly define the national policy of the People's Democracy Camp in an effort to turn the

4 Головченко В. Українсько-польські відносини: формування міждержавних взаємин у дусі Євроатлантичного партнерства. WIStA I DNIEPREM/НАД ВICЛOЮ I ДНIПРОМ. Торунь-Київ: Міжнародний науково-освітній консоричум імені Люсьєна Февра, 2017. Т. 1. С. 43, 44. 
state territory of the Polish-Lithuanian Commonwealth into national Polish territory ${ }^{5}$. In this way national Democrats had hoped to prove that the Western lands to Poland forever secured, and thus, to put an end to the hopes of Ukrainians for an independent state. At the same time, the competing "federalist concept" devotees of J. Pilsudski in 1920-1930th years became known as the doctrine of "Polish prometheism". The foreign policy of the Second Polish Republic prometeisti viewed through the prism of future conflict the civilized West, to which they reckoned and Poland, with the Communist Soviet Union. The result of this collision, as expected, was to be the disintegration of the multinational Bolshevik Empire. Released, but according to "prometiste" politically and nationally immature peoples need help in the process of nation-state. Prometeisti criticized the Warsaw Treaty of 1920 for ignorowanie the interests of the Galician Ukrainians, that led to the failure of the "Kiev campaign" of 1920. In the new phase, according to them, the Galicians can be not only a catalyst for the movement for the education of "great Ukraine" on the ruins of the Bolshevik Empire - they are the vanguard of a new liberation campaign in the East ${ }^{6}$. According to I. Sribnyak, leading Ukrainian politicians supported the Prometheus project of Y. Pilsudsky, as it was aimed at weakening Bolshevik Russia by supporting the desire for independence of the peoples previously enslaved by Moscow ${ }^{7}$.

The Second World War marked the beginning of one of the nitragic periods in the history of Ukrainian-Polish relations. As a result of double aggression against Poland by Nazi Germany and the Stalinist USSR and the distribution of Polish territories between them on the basis of secret protocols to the Nonaggression Pact of August 23, 1939 and the Treaty of Friendship and Borders of September 28 of the same year, the Western Ukrainian lands became part of Soviet Ukraine. In this situation, the Polish government, which found itself in exile in London, faced the problem of developing a new policy on the Ukrainian issue. In the emigrant government there were supporters of both the ideas of federalism, in particular the Prometheists, and traditional national democrats. The Polish government announced its position on the Ukrainian issue in a declaration of December 18, 1939, which outlined the basic principles of equality and

\footnotetext{
${ }^{5}$ Tomaszewski J. Kresy Wschodnie w polskiej mysli politycznej XIX i XX w. Miedzy Polska etniczna a historyczna. Polska mysl polityczna XIX i XX wieku. T. 6. Warszawa, 1988. S. 168.

6 Головченко В. Українсько-польські відносини: формування міждержавних взаємин у дусі Євроатлантичного партнерства. WISŁA I DNIEPREM/НАД ВICЛОЮ I ДНIПРОМ. Торунь-Київ: Міжнародний науково-освітній консорииум імені Люсьєна Февра, 2017. Т. 1. С. 45, 46.

Срібняк I. Українська політична еміграція в міжвоєнній Польщі: шляхи формування, особливості діяльності, подальша доля. WISEA I DNIEPREM/HАД ВICЛOЮ I ДНIПРОМ Польща і Україна в європейській перспективі - минуле і сучасність. Toruń-Saragossa: Miжнародна асоџіаџія істориківархівістів, 2015. T. 4. С. 158.
} 
justice in relation to national minorities and proclaimed the struggle for the return of the lost "eastern regions" .

One of the unfortunate consequences of the tough decisions the issue of borders in the interwar period (in particular the fact that more than five million Ukrainians were on the territory of Poland, and part ethnic poles made up a significant percentage of the population of Volyn) were the events that took place in 1943 in Volyn. However, the tragic events that took place there have used primarily the Soviet Communist leaders, and in the modern era of Pro-Russian politicians strongly used this historical tragedy to spoil Ukrainian-Polish political relations.

Seeing from the time of the national liberation uprising of 1794 led by Tadeusz Kosciuszko, and especially in the nineteenth century - the unity of poles and Ukrainians under the slogan "For our and your freedom!" (Za wolność naszą i waszą), the autocratic imperial power began to act insidiously - pitting Polish nationalist patriots with Ukrainian. The Bolsheviks in the twentieth century, and their followers - "Putin security officers" at the beginning of the twenty-first century achieved particular success in this.

M. Guy claims that the term "hybrid war" is simply a designation of a combination of fairly old methods and means of conducting a conventional war'. At the same time, one of the varieties of hybrid warfare was the "war of controlled chaos". This is precisely what the Bolshevik leaders used both during the national liberation struggle of 1917-1921, and during World War II. And perhaps the most telling example of this is the history of the Warsaw Uprising of 1944.

It is well known that the rebels in Warsaw expected the approach of the Red Army. But the Soviet offensive stopped, allowing the Germans to regroup and destroy the city during the suppression of the uprising. It is obvious that Stalin had the intention and ordered his marshals to wait until the Germans destroyed the Polish patriots, which Stalin did not need when building communist Poland.

By the way, Moscow radio, to a certain extent, led to an uprising against the Germans, transmitting a special message at the end of July 1944. By whose order and for what purpose this call was made on the air it is still not clear. For the sake of justice, it should be noted that a similar

8 Головченко В. Українсько-польські відносини: формування міждержавних взаємин у дусі Євроатлантичного партнерства. WISŁA I DNIEPREM/НАД ВICЛOЮ I ДНIПРОМ. Торунь-Київ: Міжнародний науково-освітній консорииум імені Люсьєна Февра, 2017. Т. 1. С. 46.

${ }^{9}$ Гай М. Россия знает, что Украина это не Афганистан, не Чечня, не Сирия. Для реальной войны в Украине, РФ должна провести колоссальную подготовку и они это делают. URL: http://patrioty.org.ua/ blogs/rossyia-znaet-chto-ukrayna-to-ne-afhanystan-ne-chechnia-ne-syryia-dlia-realnoi-voin-v-ukrayne-rfdolzhna-provesty-kolossalnuiu-podhotovku-y-ony-to-delaiut--hai-140804.html. 
call for rebellion came from London. However, London radio a few days later still did not call the rebels a "gang of criminals", as Moscow did ${ }^{10}$.

Among the SS units involved in the suppression of the Polish uprising were soldiers of the former Kaminsky brigade. A group of Russian SS men consisted of volunteers commanded by a former Red Army officer, Lieutenant Colonel (SS Obersturmbanführer) Frolov. Created back in 1941 in the Smolensk region by the repressed engineer B. Kaminsky, this military formation now totaled up to 20 thousand people. In 1944 he was turned into the twenty-ninth SS grenadier division, and B. Kaminsky himself received the rank of brigadefuhrer of the SS troops (major general).

The brutality of the Russian SS men - looting and killing of civilians caused such hatred and horror among the Poles that later, during the surrender of the rebels, one of the conditions put forward by the Germans was the removal of the Russians from the escort of prisoners. By the way, according to some reports, B. Kaminsky himself was convicted and shot on August 19 by a military court of the SS troops for falling discipline in the troops subordinate to him, robbery, etc. (according to other sources, he was killed by SD agents in the Carpathians when trying to establish contacts with the UPA). The remains of the Kaminsky brigade were later transferred to the formation of the 1st division of the Russian Liberation Army (ROA).

It is obvious that the basis for the question of assistance to Warsaw was not so military as political factors. Stalin perfectly understood the doom of the uprising without the military support of the Red Army. He realized and didn't consciously help the Warsaw, because as a politician he saw undeniable dividends in the defeat of the speech organized by the Polish emigration government opposed to him.

The attitude of the Stalinist regime towards the idea of independent Poland and, in particular, to the Craiova Army clearly manifested itself shortly after the liberation of Polish territory by the Red Army. Almost at the same time that the Germans were killing insurgents in Warsaw, the Soviet repressive and punitive bodies began "cleansing" the territory of Poland from the Army Craiova disloyal to Soviet power. According to L. Beria, I. Stalin, only for the period from October 15 to November 14, 1944, security officers arrested more than 4,200 members of the Home Army. Repressive actions continued on.

When the Red Army entered deserted and destroyed Warsaw on January 17,1945 , there was no longer any alternative to the "government"

10 Польська Прага: «російська зрада» чи «варшавська авантюра»? Український Форум. URL: http://www.ukrcenter.com/Форум/30401/Варшавське-Повстання-1944p-та-його-музей 
brought in the Soviet wagon train. The only organized opposition capable of confronting Stalinism suffered a crushing defeat. Freed from Nazism, Poland lost its independence after World War II and was plunged into the horror of totalitarianism ${ }^{11}$.

To this day, there is a myth about the participation of Ukrainians in the suppression of the uprising. Its emergence was facilitated by the Germans use of the Russian RVNA division, as well as battalions, where representatives of the Central Asian peoples served. In fact, not a single Ukrainian formation as such took part in the suppression of the Warsaw Uprising. But some Ukrainians fought against the rebels in some German units. However, for Moscow propagandists, and especially their followers from Yanukovych's entourage - like Kolesnichenkov of various kinds, the systemic task is to blame Ukrainians for all sins (such as the Volyn massacre). At the same time, the real crimes of Moscow against the Poles (Katyn, etc.) seem to fade into the background.

If the consequence of the First World War was the complete disregard on the part of large Western states of the political and state-legal interests of the Ukrainian nation, then as a result of the Second World War this was already characteristic of both Ukraine and Poland. The confrontation of two totalitarian states: Germany and the Soviet Union led to a number of tragic consequences for the Ukrainian and Polish nations. At that time, the great Western powers again ignored the possibility of the existence of a Ukrainian political nation and state independent of the USSR, and Poland, forcibly incorporated into the socialist system, actually became the political vassal of the Soviet Union. One of the most tragic pages of this period was the so-called "Ukrainian-Polish war of 1942-1947". Regarding the causes of the Ukrainian-Polish confrontation, Y. Pelensky pointed out the existence of allegations that the Ukrainian nationalist underground intended to "depolonize" the Western Ukrainian territories, in particular, for the forced eviction of the Polish population and selective fighter actions. On the other hand, the Polish government and its armed forces, the Craiova Army, tried to do everything possible to maintain the so-called state of the Polish presence on Ukrainian lands, and resorted to terrorist and military-fighter methods to implement this $\operatorname{plan}^{12}$. Victims of the bloody terorra tens of thousands of civilians $\mathrm{z}$ both sides. At first glance, quite the opposite of the London government in exile's position in the Ukrainian question was Polish left-wing forces, under the leadership of the Communists. As a tool of Stalin's diplomacy, they are recognizing the

11 Польська Прага: «російська зрада» чи «варшавська авантюра»? Український Форум. URL: http://www.ukrcenter.com/Форум/30401/Варшавське-Повстання-1944p-та-його-музей.

12 Пеленський Я. Україна в польській опозиційній публіцистиці. Подляський Казімєж. Білоруси литовці - українці: наші вороги - чи брати? Мюнхен. 1986. С. 17. 
right of Nations to self-determination, primarily disapproved of the accession of Western Ukraine to the USSR. In fact, the Polish Communists saw the USSR guarantor of their state-political existence of the future status quo restored - Third of the Commonwealth in Europe. They strongly defended the idea on the revision of the Western and Northern borders of Poland by Germany, and also about the advisability of failure in the East from napolski ethnic territories. The implementation of these plans has created the possibility of building a mono-ethnic Polish state, which at the time wanted national Democrats. So over the years 1944-1946 were implemented Ukrainian-Polish population exchange and, since September 1945, the process for Ukrainians, the so-called "UPA" had, in fact, the nature of forced deportation. Thus, international legal the results of the Second world war dramatically changed the situation in Ukrainian-Polish relations. The official doctrine in the practice of international relations and the national question the Communist Poland was the theory of proletarian internationalism, in fact, its policy towards Ukrainians was based on the lack of recognition of their liberation aspirations and focused assimilation, which has been encouraged by Moscow. To finally "solve" the Ukrainian question and to eliminate the Ukrainian national liberation movement, the Polish Communists on April 28 - August 12, 1947, carried out the action "Vistula". To more than 140 thousand Ukrainians were applied the principle of collective responsibility: from ethnic Ukrainian land to the East of the Polish Republic they were evicted and resettled in nine Western and North-Western provinces with the ultimate aim of assimilation. The deportees were under so-called administrative supervision, without the right of free movement and changes of residence. Some of such restrictions were in force until 1970-ies. During the existence of the Polish people's Republic (Poland, 1952-1989 years) Ukrainian-Polish relations were under the strict control of Moscow and was modeled from the Kremlin as the relationship between "fraternal socialist States" in the framework of Polish-Soviet relations. After the Second world war, neither in Poland nor in Ukraine did not have its own independent foreign policy, therefore, was nonexistent some full of official relations between the USSR and pnrm. On the contrary, normal communication between them was hampered by different obstacles. So, finding no way out, anti-Ukrainian sentiment and stereotypes continued to exist among the Polish public and Vice versa, the Communist elite in Poland is not only not turn away old conflicts, but also because of its authoritarian nature, further aggravated their ${ }^{13}$. However,

13 Головченко В. Українсько-польські відносини: формування міждержавних взаємин у дусі Свроатлантичного партнерства. WISŁA I DNIEPREM/НАД ВICЛOЮ I ДНIПРОМ. Торунь-Київ: Міжнародний науково-освітній консоричиум імені Люсьєна Февра, 2017. Т. 1. С. 47, 48. 
behind official relations between the NDP and the Ukrainian SSR there were other forms of communication, laying the foundation for the future strategic partnership of the already independent Ukraine and the Republic of Poland, namely dissidents, independent intellectuals, political emigration and the like.

\section{New realities of Ukrainian-Polish political relations in the process of opposing imperial encroachments by Russia}

A significant idea of the Polish conservatives in the first half of the 1990s was the so-called idea of "inter-seas", proposed by L. Mochulsky. It became a creative development of the "federalist concept" of Y. Pilsudsky and consisted in the fact that the countries of Central and Eastern Europe (the so-called "inter-seas" - the region between the Baltic and the Adriatic and the Black Sea) should be integrated as much as possible in order to preserve their independence and identity did not absorb the post-industrial West or chauvinistic Russia. At the same time, it was Ukrainian-Polish relations, according to the ideologist of the "inter-seas", that were crucial for the implementation of the entire program. But official Warsaw immediately and unequivocally determined its Central European status and clearly focused on joining all European structures and NATO. Ukraine, however, could not for political reasons, and was not socially and politically prepared for this. The Eurasian development option was discussed for a long time (according to the Russian model and by inertia), and only recently after the victory of the Revolution did dignity officially talk about the unambiguous integration of Ukraine into Europe. A model of relations between Ukraine and the enlarged EU is being developed in relations with the Republic of Poland, and in this context, the importance of Ukrainian-Polish cooperation is gaining even more weight for the entire continent, because Ukraine, as a reliable and effective partner, together with Poland form the core of stability and security in the Central Of Eastern Europe. With Poland gaining membership on NATO on March 12, 1999, and on May 1, 2004, in the EU, the nature of Ukrainian-Polish relations began to change qualitatively. Despite a number of internal problems (opposition to deepening the Ukrainian-Polish strategic partnership "left" and "right", political reform in Ukraine, etc.), there are objective prospects and interest in the further development of cooperation between our states. Poland uses a strategic partnership with Ukraine in order to gain a more significant position in European and Euro-Atlantic organizations, which would distinguish it from other member states. To this end, official Warsaw decided to take on the role of spokesman for the interests of Eastern Europe, especially Ukraine. Ukraine, for its part, can 
use the partnership with Poland in order to balance historical asymmetries with Russia (especially in the context of modern armed aggression by the latter), gain membership in the European and Euro-Atlantic community, and fully realize its democratic potential ${ }^{14}$. From the analysis of the Ukrainian-Polish strategic relations it follows that they basically came down to observing a common position in regional and European politics. To a large extent, the identical position on issues of pan-European integration made it possible to significantly accelerate the advancement of the North Atlantic Alliance and the European Union to the East. An important reinforcing factor in the process of Ukrainian-Polish rapprochement was also a significant time period necessary for successful European and Euro-Atlantic integration of the two countries. The Ukrainian leadership considered active cooperation with Poland in the political and economic field as a means of accelerating the approach of Ukraine to the structures of the European community. Polish integration into the EU turned out to be one of the main test questions that determined the fate of the declared strategic partnership between the two countries. Finally, on March 1, 1998, the Partnership and Cooperation Agreement between Ukraine and the European Union entered into force, which was to deepen the valley of Polish-Ukrainian integration.

The military-political Ukrainian-Polish cooperation significantly affected the process of forming in-depth bilateral relations, taking into account the expansion of NATO and the activation of the Partnership for Peace program. Since the mid-1990s, Ukrainian-Polish political relations have been building up the political and legal base and are gradually moving to the phase of strategic partnership. Bilateral cooperation of this level has limited the influence of negative factors on the policies of both countries and is consistent with their strategic national interests ${ }^{15}$.

It is the military-political Ukrainian-Polish cooperation, especially given the process of NATO expansion, that is an important guarantee of joint opposition to imperial encroachments on the part of the Russian Federation.

In recent years, especially after the victory of the Dignity Revolution of 2014, Poland willingly acts as the European lobbyist and lawyer of Ukraine, seeks to monopolize the role of the developer of the eastern direction of the EU's "neighborhood policy", fill it with the real prospect

14 Головченко В. Українсько-польські відносини: формування міждержавних взаємин у дусі Євроатлантичного партнерства. WISŁA I DNIEPREM/НАД ВICЛOЮ I ДНIПРОМ. Торунь-Київ: Міжнародний науково-освітній консорииум імені Люсьєна Февра, 2017. Т. 1. С. 49, 50.

${ }^{15}$ Гудзь В., Гудзь В. Політичні відносини України з Республікою Польща наприкінці ХХ століття. WISEA I DNIEPREM/НАД ВICЛOЮ I ДНIПРОМ Польща і Україна в європейській перспективі - минуле і сучасність. Збірник наукових праць на пошану професора Омеляна Вішки (1940-2014). Торунь-Київ: Міжнародний науково-освітній консорцииум імені Люсьєна Февра, 2017. Т. 1. С. 41, 42. 
of full-scale Euro-Atlantic integration and does not mind taking on the role of conductor Ukraine to the mentioned community ${ }^{16}$.

It's hard to deny that the Kremlin regime best anti-Ukrainian hysteria in Poland today, with trampling the Ukrainian flag, ukrainofobskikh of the calls, and the like. It is against this background and the desire to investigate the true circumstances of the accident on April 10, 2010 plane Tu-154 near Smolensk, leveled. However, modern Russia's hybrid war against Ukraine is becoming for the poles is not as relevant. However, as history shows, following the Ukraine may be the same as Poland or the Baltic States. And if not as a direct aggression, then give it a hybrid version.

One of the indicators of a hybrid war in Ukraine is the use of asymmetric fighting, which is characterized by a significant difference in military strength and strategy of the parties involved. From the point of view of international law this strategy is that Ukraine has no formal grounds to fight with the aggressor, who informally support the militants and terrorists. So on the territory of Ukraine acted diversified agents of the intelligence services of the Russian Federation. At the same time, Russia supplies them with weapons and new mercenaries lead shelling of positions of Armed forces of Ukraine from its territory. In an undeclared war against Ukraine, Russia actively uses methods of informationpsychological war, trying to destroy the morale of the troops and the civilian population of the Ukrainian state ${ }^{17}$. At the same time, Kremlin leaders know that Ukraine is not Afghanistan, not Chechnya, and not Syria. An easy walk, given that they lost everywhere, this war will not be. But the geographical proximity, the homogeneity of bureaucracy and business, the corruption of the "elite" play a negative role ${ }^{18}$.

V. Gorbulin noted that the West, for its part, essentially - "washing their hands", allowed all this to happen. Western analysts, in particular Peter Dickinson in their material for the Atlantic Council, are talking more and more clearly about this. He notes that most of the Western media immediately after the Russian aggression against Ukraine suddenly "blinded" about who the aggressor was in the Ukrainian conflict and what the occupation forces should be called, inventing in return some new words and phrases whose only meaning is not to name the Russian aggression as $\operatorname{such}^{19}$.

16 Головченко В. Українсько-польські відносини: формування міждержавних взаємин у дусі Свроатлантичного партнерства. WIStA I DNIEPREM/НАД ВICЛOЮ I ДНIПРОМ. Торунь-Київ: Міжнародний науково-освітній консорииум імені Люсьєна Февра, 2017. Т. 1. С. 43.

17 Парубій А. Війна Росії проти України і світу. Украӥнська Правда. 2014. 6 серпня 2014. URL: http://www.pravda.com.ua/articles/2014/08/6/7034046/

${ }^{18}$ Гай М. Россия знает, что Украина это не Афганистан, не Чечня, не Сирия. Для реальной войны в Украине, РФ должна провести колоссальную подготовку и они это делают. URL: http://patrioty.org.ua/blogs/rossyia-znaet-chto-ukrayna-to-ne-afhanystan-ne-chechnia-ne-syryia-dlia-realnoivoin-v-ukrayne-rf-dolzhna-provesty-kolossalnuiu-podhotovku-y-ony-to-delaiut--hai-140804.html.

19 Горбулін В. Хитромудра невизначеність нового світо порядку. URL: http://gazeta.dt.ua/ internal/hitromudra-neviznachenist-novogo-svitoporyadku-_.html. 
According to Turchenko F. G. Turchenko, the current RussianUkrainian war refers to the type of armed conflict which are called "hybrid", "non-linear", "non-conventional". In wars of this type are used various ways of dealing with the enemy. In General, the characteristics of hybrid wars following: aggression without a formal Declaration of war; concealment of the aggressor of their participation in the conflict; "Information warfare" - propaganda and counter-propaganda using "dirty" information technology; the widespread use of "fifth column" and irregular forces (including under the guise of civilians) the neglect of the aggressor by the international rules of warfare, existing agreements and new agreements; measures of political and economic pressure (in the formal preservation of diplomatic relations between the two countries) confrontation in cyberspace, and the like. Information war of Russia against Ukraine in fact began immediately after the proclamation of independence of Ukraine and has become very aggressive forms since the annexation of Crimea. Actually, it was an attempt to mislead not only the citizens of Ukraine but also the Russian citizens, the international community as a whole ${ }^{20}$.

Most international military experts acknowledge that there is a threat of new conflicts in Europe, and Russian aggression threatens the security of not only Ukraine, but all of Europe. In a hybrid war on one's own territory, it is difficult to defeat, since there are no borders in it. Therefore, it was this factor that influenced the miscalculations of the Ukrainian authorities in conducting the anti-terrorist operation. The Ukrainian-Russian border cannot be blocked if Ukraine does not control the information space and air of the East of Ukraine. At the same time, terrorists will continue to carry out provocations on the border and in occupied territories for informational support to Russian media. The network actions of terrorists in the occupied territory, together with the support of Russian troops at the border, will constantly allow Russia to continue delivering terrorists, weapons and ammunition to Ukrainian territory. Therefore, until the information space in the Donbass is controlled, Ukraine will not be able to count on the support of its own population in the conflict region. Such a situation will contribute to the formation of a permanent social base for the terrorists of the LNV and $\mathrm{DPR}^{21}$.

Thus, it should be noted that most wars are not only armed in military nature, quite often they have a close relationship with the psychological impact on people's minds through agitation, propaganda and other means

${ }^{20}$ Турченко Ф., Турченко Г. Проект «Новоросія» $і$ новітня російсько-украӥнська війнаурченко. К.: Інститут історії України НАН України, 2015. С. 143.

${ }^{21}$ Дацюк С. А. Стратегія перемоги України у війні з Росією. URL: http://blogs.pravda.com.ua/authors/ datsuk/53a5542ba2a4a/. 
of influence. This is especially true of the modern hybrid war unleashed by the Kremlin against Ukraine.

At present, the active opposition of Ukraine to the actions of the Russian Federation, including with the use of military force, has not allowed to fully realize the "Crimean" scenario in the east of our country. In fact, the hybrid war of Russia against Ukraine turned into an armed conflict between the two countries with the direct involvement of troops of both sides. At the same time, despite the attempts of the Russian side to hide the participation of their armed forces in the specified conflict, this fact was recognized by the overwhelming majority of the world community, which led to the strengthening of US and EU sanctions against Russia $^{22}$. And given all this, there is a rhetorical question: isn't it sufficient for poles and Ukrainians to look for in the historical jungle of sedition against one another, blame one another in the former troubles and grievances? At that time, as a common historical enemy - Kremlin regime - and uses any opportunity to the next provocation and inspiration of conflict between poles and Ukrainians.

In General you should summarize that if the result of the First world war was the complete disregard by the major Western countries and political and public-legal interests of the Ukrainian nation, the result of the Second world war this has been true both for Ukraine and for Poland. The confrontation between the two totalitarian States: Germany and the Soviet Union led to a series of tragic consequences for the Ukrainian and the Polish nation. In that time, the Western powers once again ignored the possibility of independent from the Soviet Union the existence of the Ukrainian political nation and the state, and Poland forcibly incorporated into the socialist system, in fact, has become a political vassal of the Soviet Union.

It should be noted that in our time the military-political UkrainianPolish cooperation, particularly given the process of NATO expansion, are crucial to ensure a joint opposition to Imperial encroachments of Russia.

\section{SUMMARY}

An attempt was made to consider to perform Ukrainian-Polish political relations in the context of opposition to the Imperial encroachments of Russia. In particular describes the historical vision of Ukrainian-Polish political relations, given the opposition to the Imperial encroachments of Russia and described the new realities of Ukrainian-

\footnotetext{
22 СИТНИК О. Досвід російсько-української війни 2014-2017 років у контексті україно-польських історичних відносин. NAD WISEA I DNIEPREM/НАД ВICЛOЮ I ДНIПРОМ. Польща і Україна в європейській перспективі - минуле і сучасність. Збірник наукових праць на пошану професора Омеляна Вішки (1940-2014). Торунь-Київ: Міжнародний науково-освітній консорииум імені Люсьєна Февра, 2017. T. 1. С. 185 .
} 
Polish political relations in the process of opposition to the Imperial encroachments of Russia. Traced the joint struggle of Ukraine and Poland for independence and opposition to Russian Imperial expansion.

\section{REFERENCES}

1. Головченко В. Українсько-польські відносини: формування міждержавних взаємин у дусі Євроатлантичного партнерства. WISŁA I DNIEPREM/НАД ВІСЛОЮ I ДНІПРОМ Польща $i$ Україна в європейській перспективі - минуле і сучасність. Збірник наукових пращь на пошану професора Омеляна Вішки (1940-2014). ТоруньКиїв: Міжнародний науково-освітній консорциум імені Люсьєна Февра, 2017. Т. 1. С. 43-51.

2. Дашкевич Я. Україна у вогні ідеологій. Кісь Р. Фінал Третього Риму (Російська ідея на зламі тисячоліть). Львів: Вид-во отців Василіян "Місіонер", 1998. С. I-XIV.

3. Tomaszewski J. Kresy Wschodnie w polskiej mysli politycznej XIX i XX w. Miedzy Polska etniczna a historyczna. Polska mysl polityczna XIX i XX wieku. T. 6. Warszawa, 1988. S. 167-186.

4. Срібняк I. Українська політична еміграція в міжвоєнній Польщі: шляхи формування, особливості діяльності подальша доля. WISŁĄ I DNIEPREM/НАД ВІСЛОЮ І ДНІПРОМ Польщза $і$ Україна в європейській перспективі - минуле $і$ сучасність. Toruń-Saragossa: Міжнародна асоціація істориків-архівістів, 2015. Т. 4. С. 155-159.

5. Поляки i українці між двома тоталітарними системами. 1942-1945. Упорядн.: Б. Гронек, С. Кокін, П. Кулаковський та ін. Редкол.: С. Богунов, М. Вінярчик-Коссаковська, 3. Гайовнічек та ін. Державний архів Служби безпеки України; Архів Міністерства внутрішніх справ і Адміністрації Республіки Польща. Інститут національної пам'яті - Комісія 3 переслідування злочинів проти польського народу; НАН України. Інститут політичних i етнонаціональних досліджень. Варшава; Київ, 2005. Т. 4. Ч. 1. 1512 с.

6. Ситник О. Досвід російсько-української війни 2014-2017 років у контексті україно-польських історичних відносин. NAD WISŁĄ I DNIEPREM/НАД ВІСЛОЮ I ДНІПРОМ. Польщза $i$ Україна в європейській перспективі - минуле і сучасність. Збірник наукових працьь на пошану професора Омеляна Вішки (1940-2014). ТоруньКиїв: Міжнародний науково-освітній консорциум імені Люсьєна Февра, 2017. Т. 1. С. 182-185.

7. Гай М. Россия знает, что Украина это не Афганистан, не Чечня, не Сирия. Для реальной войны в Украине, РФ должна провести колоссальную подготовку и они это делают. URL: http://patrioty.org.ua/ blogs/rossyia-znaet-chto-ukrayna-to-ne-afhanystan-ne-chechnia-ne-syryia- 
dlia-realnoi-voin-v-ukrayne-rf-dolzhna-provesty-kolossalnuiu-podhotovkuy-ony-to-delaiut--hai-140804.html

8. Польська Прага: “російська зрада" чи “варшавська авантюра”? Український Форум. URL: http://www.ukrcenter.com/Форум/30401/ Варшавське-Повстання-1944p-та-його-музей

9. Пеленський Я. Україна в польській опозиційній публіцистиці. Подляський Казімєж. Білоруси - литовці - українці: наші вороги - чи брати? Мюнхен. 1986. С. 10-23.

10. Гудзь В., Гудзь В. Політичні відносини України 3 Республікою Польща наприкінці XX століття. WISŁĄ I DNIEPRЕМ/НАД ВІСЛОЮ І ДНІПРОМ Польща $i$ Украӥна в європейській перспективі - минуле і сучасність. Збірник наукових пращь на пошану професора Омеляна Вішки (1940-2014). ТоруньКиїв: Міжнародний науково-освітній консорциум імені Люсьєна Февра, 2017. Т. 1. С. 40-42.

11. Парубій А. Війна Росії проти України і світу. Українська Правда. 2014. 6 серпня 2014. URL: http://www.pravda.com.ua/ articles/2014/08/6/7034046/

12. Гай М. Россия знает, что Украина это не Афганистан, не Чечня, не Сирия. Для реальной войны в Украине, РФ должна провести колоссальную подготовку и они это делают. URL: http://patrioty.org.ua/blogs/rossyia-znaet-chto-ukrayna-to-ne-afhanystanne-chechnia-ne-syryia-dlia-realnoi-voin-v-ukrayne-rf-dolzhna-provestykolossalnuiu-podhotovku-y-ony-to-delaiut--hai-140804.html.

13. Горбулін В. Хитромудра невизначеність нового світо порядку. URL: http://gazeta.dt.ua/internal/hitromudra-neviznachenistnovogo-svitoporyadku-_.html.

14. Турченко Ф., Турченко Г. Проект “Новоросія" $i$ новітня російсько-українська війнаурченко. К.: Інститут історії України НАН України, 2015. 166 с.

15. Дацюк С. А. Стратегія перемоги України у війні з Росією. UR L: http://blogs.pravda.com.ua/authors/datsuk/53a5542ba2a4a/.

\section{Information about the author: Sytnyk O. M.}

Doctor of Historical Sciences, Associate Professor, Head of the Department of History, Archeology and Philosophy, Bogdan Khmelnytskyi Melitopol State Pedagogical University 41/7, Universitetska str., Melitopol, Zaporizhzhia region,

72312, Ukraine 


\section{HOW IMPERIAL HISTORIANS BECAME NATIONAL: THE EXAMPLE OF ONYKII MALYNOVSKYI}

\section{Yaremchuk V.P.}

\section{INTRODUCTION}

A turn of the 19th and 20th centuries was pivotal to the nationbuilding of the East-Central European space. The national projects, formed in the intellectuals' texts and the programs of the national movements, were factually executed in the process of the collapse of the Romanov and Habsburg empires. The stands of the "national" historians of the new states were studied and comprehensible enough due to their active part in the state establishment. The logic of the historical writing and the civilian activities, for example of the Ukrainian Mykhailo Hrushevskyi or Lithuanian Ignas Jonynas, was very similar despite the individuality of their research and political paths. It is more difficult to answer the question on how the yesterday's decent imperial cultural figures, for instance, the professors of the imperial universities, became the key players of the already national cultures as well as the national historians - either in Ukraine and Belarus, controlled by the Bolsheviks, or in the independent Baltic states. Obviously, they were greatly influenced by the new national and political realias and acted not as engines (subjects) of the national and political reformation on the territory of East-Central Europe but as its [reformation] passive (without any negative connotations) objects. However, such an assumption is very general. Thus, it needs factual verification. In order to understand the causes of the ideological evolution of the cultural figures in the conditions of the appearance of national cultural space on the imperial ruins, it is necessary to study their life journey in the widest possible context. The reasoning of a general nature is indispensable here. Without it, the historians are doomed to the spread in literature superficial speculations about the "national treason" of the ones (for example, Ivan Lynnychenko - the student of one of the creators of modern Ukraine Volodymyr Antonovych, who, as we all know, condemned Ukrainians for their race for independence) and "national self-sanctification" of the others (for instance, Oleksandra Yefymenko the author of one of the first synthesis of the Ukrainian history).

The transnational perspective can serve as a methodological matrix, which will contribute to the deeper insight into the intellectuals' individual world. Obviously, the study of the fate of the imperial intellectuals in times 
of the crisis of empires (as well as their stands, self-identification, the vision of the world and themselves in the conditions of such crises) in terms of history, which comes solely from the national historical models, is unproductive. This situation was argued well, for instance, by Andreas Kappeler. In 2012, he published an interesting, thorough and replete with unconventional observations "crossed" mutual biography of a married couple of the Ukrainian ethnographer, statistician and a member of the Ukrainian movement Petro Yefymenko and the above-mentioned historian, "self-learner, women and katsap" (according to the accurate statements of the same Western historian) Oleksandra Yefymenko ${ }^{1}$. As A. Kappeler has convincingly demonstrated, the biography of O. Yefymenko cannot be satisfactorily explained through the lens of exceptional loyalty, only Russian or Ukrainian "segments" of her legacy or life journey. In addition to them, coincidences, mishaps, everyday causes, which escaped the researchers' attention previously, such as the struggle for survival under conditions of a serious economic situation of the family, very often affected her.

\section{Life Journey and Intellectual Legacy of O. Malynovskyi}

It is high time to move to the story of "the hero" of our article. The destiny and posthumous memory about Onykii O. Malynovskyi (1865-1932) were not favourable to the scientist. They do not require a detailed description because his biography in its traditional sense (as an accumulation of data about the biological, family, artistic and civic and political life) is mainly known nowadays. Today, after a long period of obliviousness in Soviet times, the researchers' interest in him has significantly increased. To date, the Ukrainian and Russian historians and lawyers have published several dozens of encyclopedic slogans, more or less substantial articles about the scientist and the excerpts of some of his memorial texts, written at different times. One of the scientific training departments of the university in the city of his birth, Ostroh Academy, is named after $\mathrm{O}$. Malynovskyi. At the same time, annual international conferences to commemorate him are held here; their materials are published; several scientific and scientific popular works of O. Malynovskyi are republished. The most important of the latter is the revised edition of the generalized and, to some extent, summarized work of both O. Malynovskyi and the school of "law of Western Rus", to which he belonged, - "Lektsii po istorii russkoho prava" (The Lectures on the

${ }^{1}$ Див: Kappeler A. Russland und die Ukraine: verflochtene Biographien und Geschichten. Wien; Köln; Weimar, 2012.395 s. 
History of Russian Law) ${ }^{2}$ on the basis of Rostov edition of 1918, published in $2015^{3}$.

O. Malynovskyi was born in a family of craftspeople. He managed to reach the top of the academic recognition, became a Ph.D. in History of "Rus' law", the lead professor of several universities in the Russian empire, and starting from 1925 - an academician of the All-Ukrainian Academy of Science. On the other hand, he was always on the top of the liberal and democratic opposition to the self-contained regime. Also, he was an editor and author of the oppositional editions because of which he repeatedly suffered in the career plan. In 1920, with the establishment of Bolshevism, he, as a "counter-revolutionary", was sentenced to capital punishment, which was substituted with the imprisonment in the last moment. In 1925, the scientist was released on parole. After moving to Kyiv in 1926-1930, he worked productively in the All-Ukrainian Academy of Science. He was the head or a member of a myriad of academic institutions. With the start of Stalin's purges, the scientist was stripped of the title of academician and all academic posts. On many occasions, fate put him to test in a personal sphere of life. At a very young age, he was destined to cope with terrible grief. In the spring of 1884 , because of a landslide, his father and brother Volodymyr tragically died. In 1911, his apartment in Tomsk, where he lived and taught at a university from 1898 to 1913 (the scientist was fired from the university in 1911 due to his "unreliability"), burned during the fire. In the last years of his life, he suffered from progressive diseases, deafness in particular, which were the result of Malynovskyi's huge scientific and socio-political workload throughout his life.

In 1888-1892, O. Malynovskyi studied at the History and Philology Department and, then, at the Law Department at the University of Saint Volodymyr. There he entered the students' circle of the famous legal historian Mykhailo Vladymyrskyi-Budanov and became one of the representatives of a research team of mainly the students of this very scientist. Onykii Malynovskyi himself called it "the school of research scientists of Western-Russian times", and today's historians call it "the school of Western-Russian law" (Serhii Mykhalchenko ${ }^{5}$ ) or "Kyiv history and law school" (Tetiana Bondaruk ${ }^{6}$ ). The focus of this non-formal scientific association was the history of the law of the Grand Duchy of

\footnotetext{
${ }^{2}$ Малиновский И. Лекции по истории русского права. Ростов-на-Дону, 1918. 497 с.

${ }^{3}$ Малиновский И. А. Лекции по истории русского права. Москва, 2015. 696 с.

4 Ibid. C. 31.

5 Михальченко С. И. Киевская школа в российской историографии (Школа западно-русского права). Москва; Брянск, 1996. 186 с.

6 Бондарук Т. Західноруське право: дослідники і дослідження (Київська історико-юридична школа). Київ, 2000. 160 с.
} 
Lithuania. Their works, at least those published till the end of the 1910s, were based on several common ideas shared by O. Malynovskyi as well. For instance, all school representatives proceeded from the premise that "national unity" of the Slavic people, who were considered to be solid and were usually called "Russian", was typical of Kyivan Rus ("the ancient Russia" in the terminology of the school representatives). Then, this national unity was conserved in the Grand Duchy of Lithuania through a relatively peaceful inclusion of "Western Rus" in the state, which these and other imperial historians-lithuanists (Matvii Liubavskyi, Ivan Lappo) called "Litovsko-russkim gosudarstvom" ("the Grand Duchy of Lithuania"). Thus, a mainly "Russian" ethnic composition and the legal nature of this formation were emphasized. On the basis of the usage of the key methodological school instrument - the comparative method, particularly the comparison of the "ancient Russia" law and the law of Grand Duchy of Lithuania, the conclusion was drawn that the judicial order of Kyivan Rus was the first genealogical level of the state and law formation in the Grand Duchy of Lithuania.

Let us briefly outline the most important achievements of O. Malynovskyi as a historian of the Grand Duchy of Lithuania. His first major research in general and in the sphere of the history of the law of the Grand Duchy of Lithuania was a monograph "Uczenie o prestuplenii po Litovskomu statutu" (A Study on the Crime According to the Lithuanian Statute $)^{7}$. This book is a part of his student's work on the topic "Ugolovnoie pravo Litovskoho statuta $\mathrm{v}$ sviazi s razvitiem ugolovnoho prava voobshche" (The Criminal Law of the Lithuanian Statute in Relation with the Development of Criminal Law in General), for which he obtained the gold medal of the Board of the University of Saint Volodymyr. The study was dedicated to the poorly researched at the time of its publication question. As all three revised editions of the Lithuanian statute were interconnected, the scientist examined their contents altogether, indicating every time "whether a certain resolution is present in one, two or all three revised editions, and what modifications this resolution has undergone in the last two cases" ${ }^{\prime \prime}$. Thanks to such a method, O. Malynovskyi managed to avoid repetitions, which would be impossible to do when reviewing resolutions of every revised edition separately, as well as depict the historical genesis of different criminal law institutes.

The author thoroughly analyzed the outer structure and contents of the criminal laws of the Lithuanian statute, shed the light on its contributors'

\footnotetext{
${ }^{7}$ Малиновский И. Учение о преступлении по Литовскому статуту. Киев, 1894. 232 с.

${ }^{8}$ Ibid. C. 1.
} 
understanding of such notions as crime, corpus delicti, types of crimes and penalties.

Analyzing the legal skills of the lawyers of the Grand Duchy of Lithuania, O. Malynovskyi was reaching the conclusion that the description of crimes in the Lithuanian statute was casuistic. "Wordiness, frequent repetitions of one and the same resolutions, casuistry and (as a result) law incompleteness", these, according to the historian, are the typical features of the Lithuanian statute, which signifies a poor development of the legislative technique of codifiers in the 16 century ${ }^{9}$.

The most famous monographic study of O. Malynovskyi, which made him one of the best researchers in the field of law history in Russia, was "Rada Velikoho kniazhestva Litovskoho v sviazi s boiarskoi dumoi drevnei Rossii" (The Council of the Grand Duchy of Lithuania in Connection with the Boyar Duma of ancient Russia). The work is a comparative study of two bodies of power - the Boyar Duma of Kyivan Rus and the Council of Lords of the Grand Duchy of Lithuania. If the Boyar Duma was an institution studied well by the imperial historiography, the Council of Lords of the Grand Duchy of Lithuania as an object of the research did not attract the attention of the legal historians for a long time.

In the first part of the book ${ }^{10}$ the author mainly repeats the conclusions drawn by Vasyl Kliuchevskyi about a significant social status of the Old Russian aristocracy (the boyards), which gave grounds for its participation in the supreme power ${ }^{11}$. According to O. Malynovskyi, the meetings of kniazes and boyars (in other words, the Boyar Duma) were legally necessary for kniazes, which was fixed by the customary law. In the historian's opinion, the Boyar Duma was running the country along with the kniaz and veche (here, as in his other works, O. Malynovskyi was sticking to the well-known concept of M. Vladymyrskyi-Budanov about the triad of power (the three "beginnings") in Kyivan Rus. Its bearers were the kniaz (the monarchical element), the Boyar Duma (aristocratic) and the veche (democratic). However, its role in the exercise of supreme power as well as the relationships between the kniaz and the veche were not stable. They were defined by the specific conditions of a particular case ${ }^{12}$.

The most important from the point of view of scientific novelty, the presence of conclusions and generalizations was the first edition of the second part of the monograph ${ }^{13}$, devoted to the problem of the origin of the

\footnotetext{
${ }^{9}$ Ibid. C. 12.

${ }^{10}$ Малиновский И. Рада Великого княжества Литовского в связи с боярской думой древней России. Томск, 1903. Ч. I: Боярская дума древней России. IV, 201 с.

${ }^{11}$ Ibid. C. $70,80$.

${ }^{12}$ Ibid. C. 103.

${ }_{13}$ Малиновский И. Рада Великого княжества Литовского в связи с боярской думой древней России. Томск, 1904. Ч. II: Рада Великого княжества Литовского. Вып. 1. IV, 132 с.
} 
Council of the Lords of the Grand Duchy of Lithuania. Here the questions about the conditions of creating the Grand Duchy of Lithuania, forming the aristocracy in this country and its role in the process of genesis of the Grand Duchy of Lithuania as well as the problem of establishment of the Council of Lords as the institution of power were considered.

If in the Old Russian times the structure of the supreme power was characterized by a relative equilibrium of the three "beginnings", then very soon "those special circumstances, which accompanied the establishment of Moscow and Lithuanian-Russian sovereignty, influenced the peculiarities of the system of Moscow and Lithuanian-Russian government: the monarchical beginning dominated in Moscow, and the aristocratic - in Lithuania"14. According to O. Malynovskyi, the role of aristocracy in the governance of the country in the Grand Duchy of Lithuania increased even more compared to its place in Kyivan Rus due to two reasons: because of direct participation of "the higher levels of aristocracy - the kniazes and boyards, or landowners [...] as the closest assistants and co-workers of the great kniaz" and because of "the influence of the system of government of the neighboring Russian lands, where the Boyar Duma existed as a permanent institution, on Lithuania" 15 in the process of establishment of the Grand Duchy of Lithuania. The highest body of power that expressed the interests of aristocracy in the Grand Duchy of Lithuania was the Council of Lords. O. Malynovskyi considered that the Council of Lords (as well as local seims and general seim) was an institution with a genetic relation to the Boyar Duma of Old Rus: "The oldest right of the aristocracy to sit in the Boyar Duma changed to the right to participate in the local seims, on the one hand, and the right to sit in the council and take part in the general seims, on the other hand, at a later (Lithuanian) period" ${ }^{\text {"16. }}$.

The scientist deliberately paused on the circumstances of all Council meetings from 1324 to 1488 . However, he did not state the exact date of the creation of the Council of Lords as a state institution. His conclusions are very careful: "We cannot tell when the council under the Grand Duke of Lithuania appeared exactly. However, we can assume that it happened early enough", and it occurred "with invisible, subtle gradualism"17. Considerable attention in the book is also paid to the analysis of the composition, regime of work and functions of the Council of Lords.

\footnotetext{
${ }^{14}$ Ibid. C. 1.

${ }^{15}$ Ibid. C. 118.

${ }^{16}$ Ibid. C. 21.

${ }^{17}$ Ibid. C. 118.
} 
The second edition of the second part ${ }^{18}$, dedicated to the history of the Council of Lords during 1492-1569, had the biggest volume out of all three books of the monograph by O. Malynovskyi. An important theoretical foundation of this volume of the historian's work is the timeline of the history of the highest state institution of the Grand Duchy of Lithuania. O. Malynovskyi suggested distinguishing two stages in the history of the Council of Lords - till 1492 ("the period of the council creation") and after 1492 to 1569 ("the period of the council domination") ${ }^{19}$.

O. Malynovskyi believed that the beginning of the second stage was marked by the privilege of the Grand Duke Oleksandr in 1492, who transformed the Council of Lords into the highest body of power in the Grand Duchy of Lithuania. The book thoroughly examines the composition, working procedures and competencies of the Council of Lords at the height of its power. To the scientist's view, as "the customary law does not possess accuracy and certainty", then "the definite answers to the questions about the organization and activities of the Council as well as its relationship with the Grand Duke and seim cannot be provided. Such nature corresponds to the historical reality: a custom provides only general, imprecise directions regarding the organization and terms of reference of the state institutions and separates one institution from another only with general, imprecise features" 20 .

In the third book of his monograph, O. Malynovskyi put forward and supported an important conclusion that the source and beginning of the representational system in the Grand Duchy of Lithuania are the Council of Lords. According to the legal historian, the general seims of the state of Lithuania were only extended meetings of the Council of Lords with the participation of the nobility-knighthood but with the leading role of the Council of Lords in them. The introduction of a real representational system with the election of deputies out of nobility started not long before the end of the Grand Duchy of Lithuania as an independent state according to the Lithuanian statute of $1566^{21}$.

The publication of the first and third books of the monograph was preceded by the publication of a collection of documents ${ }^{22}$ and appendixes

18 Малиновский И. Рада Великого княжества Литовского в связи с боярской думой древней России. Томск, 1912. Ч. II: Рада Великого княжества Литовского. Вып. 2. (1492-1569). 492 с.

${ }^{19}$ Ibid. C. II.

${ }^{20}$ Ibid. C. III.

${ }^{21}$ Ibid. C. 115-116.

22 Сборник материалов, относящихся к истории панов-рады Великого княжества Литовского. Томск, 1901. 693 с. 
to $\mathrm{it}^{23}$ regarding the history of the Council of Lords. It contains rich material taken by the contributor from the so-called Lithuanian metrics as well as the civil register of Kyiv Central Archive of that time. The documents from the collection are grouped into four parts. The first part includes the privileges of the members of the Council of Lords and privileges granted with the participation of this state institution to the other people. They provide an opportunity to determine the composition of the Council of Lords. The second part contains the acts regarding the political role of the highest body of power of the state of Lithuania. The third part includes the judicial acts, in other words, the decisions of the highest court consisting of the Grand Duke and the Council of Lords, and sometimes separate sentences of the Council of Lords. The fourth part presents the documents about the "everyday" history regarding the life and activities of the members of the Council of Lords. The collection contains detailed indexes: personal, geographic and subject.

At the behest of Saint-Petersburg Academy of Sciences, M. Vladymyrskyi-Budanov wrote a review of O. Malynovskyi's works about the Council of Lords of the Grand Duchy of Lithuania ${ }^{24}$ in 1914. Despite pointing out a number of drawbacks (for example, Mykhailo Flehontovych highlighted the absence of an accurate notion of "aristocracy", insufficient consideration of the question of the origin of the Council of Lords, incompatibility of the claims about the complete succession between the Old Russian Boyar Duma and the Council of Lords in the Grand Duchy of Lithuania), he commended Malynovskyi's works on history of the highest body of power of the Grand Duchy of Lithuania. At the same time, the review emphasizes the importance of both the scientific conclusions and the methodological advantages of his texts (primarily, the logical completeness of the experiment, the consistency between the conclusions and facts, the objectivity and balance in his assessment). On the basis of Vladymyrskyi-Budanov's feedback, a cycle of studies of O. Malynovskyi on the history of the Council of Lords was awarded the Batiuskov prize of the Saint-Petersburg Academy of Sciences ${ }^{25}$.

O. Malynovskyi attempted to prepare a generalized course of the history of "Russian" law. Warsaw edition of "Lektsii po istorii russkoho prava" (The Lectures on the History of Russian Law) $(1914,1915)$ was released in two volumes. Later, the author united them into one (Rostov-on-Don, 1916; reprint in 1918; new reprint in 2015). The book

\footnotetext{
23 Сборник материалов, относящихся к истории панов-рады Великого княжества Литовского. Добавление. Томск, 1912. 139 с.

24 Владимирський-Буданов М. Рада Великого Князівства Литовського. Записки соціальноекономічного відділу [УАН]. Київ, 1926. Т. IV. С. 204-237.

${ }^{25}$ Ibid. C. 204.
} 
was an example of an innovative synthesis and a unique intellectual result of the scientific heritage of the imperial historians of the "Russian" law, particularly the representatives of the school of the "Western-Russian law". The first who noted the novelty of this work was the famous Ukrainian legal historian, an academician of the All-Ukrainian Academy of Science Mykola Vasylenko. He highlighted that O. Malynovskyi was the first to introduce the history of the "Western-Russian law" in the university series of lectures on the "Russian law" and clearly outline the history of all the branches of law, not only of the state $\operatorname{law}^{26}$. Indeed, the book contains rich and interestingly presented material on the history of the state, criminal, civil and judicial law as well as an informative essay about the sources of the history of the "Russian" law. It distinctly declared the school main principles, for example, a thesis about the "national unity" of "Russian people" (other terms used in the book "Slavs", "Russian Slavs") since the times of "the Russian state" of "ancient Russia". For instance, in the preface, explaining the notion of the subject of the history of the "Russian law", he calls it "the law of the Russian people" and expands it beyond the Slavs of the Great Russian states: "Currently, one of the most important ancient Russian lands Galicia is a part of Austria-Hungary. The population of Galicia is Russian and the law, established among these people, is Russian. Then, in the Middle Ages, two states, Moscow and Lithuanian-Russian, were formed from separate Old Russian lands. The majority of the population of both states were the Russian people, and the law, developed by the Russians of both states, is the Russian law. It means that both Moscow and Lithuanian-Russian law should be called the Russian law, and the general course of the history of Russian law should include both the history of Moscow law and the history of the Lithuanian-Russian law"27.

\section{National Identity and Political Loyalty of the Scientist}

Without doubts, the credit for highlighting the importance of the political and legal culture of Kyivan Rus in the establishment of the legal order of the Grand Duchy of Lithuania as well as studies into the specific institutions of law of this state, based on the thorough analysis of the sources, goes to O. Malynovskyi and other school representatives. In fact, O. Malynovskyi, as other imperial historians-lithuanists, was working on the multinational/transnational range of problems regarding the Lithuanian, Belarusian and Ukrainian past. However, they studied it from a purely

26 Василенко М. Передмова. Праці комісії для виучування історії західньо-руського та вкраӥнського права. Київ,1925. Вип. 1. С. III.

${ }^{27}$ Малиновский И.А. Лекции по истории русского права. Москва, 2015. С. 19. 
"supranational" perspective typical of the historical science of the Russian empire. Such a critical weakness of the approaches of school representatives was noticed by the disrupter of the scheme typical of the imperial historiography Mykhailo Hrushevskyi at the beginning of the 20 century.

Thus, let us give the floor to the most famous Ukrainian historian. In his well-known "manifest" "Zvychaina skhema "russkoii" istorii i sprava natsionalnoho ukladu istorii skhidnoho slovianstva" ("A typical Scheme of the "Russian" History and the Matter of an Effective System of the History of Eastern Slavdom") (1904), he stated: "The Grand Duchy of Lithuania was a very inhomogeneous and not unanimous body. The new science neglects and sometimes even ignores the meaning of the Lithuanian element. The study into the connection of the Old Russian law with the law of the Grand Duchy of Lithuania, the meaning of the Slavic element in the process of creation and development of the Grand Duchy of Lithuania led the contemporary researchers of the internal structure of this state to such extreme that they completely ignore the Lithuanian element [...]. Then, leaving out the Lithuanian, the Slavic element of the Grand Duchy of Lithuania by itself is not unanimous: we have two nations here - Ukrainian and Belarusian. The Ukrainian lands, excluding Pobuzhzhia and Pynshchyna, were quite mechanically connected with the Grand Duchy of Lithuania. They stood by, lived their local life, and due to the Union of Lublin, became a part of Poland. On the contrary, the Belarusian lands were closely connected with the Grand Duchy of Lithuania and had a significant influence on it - in the sphere of the public and political order, law and culture (on the other hand, they were greatly influenced by the public and political as well as cultural processes of the Grand Duchy of Lithuania) and remained a part of it till the end. Therefore, the history of the Grand Duchy of Lithuania is far more closely connected with the history of the Belarusians than the Ukrainian-Russians [...]"28. As we can see, M. Hrushevskyi called for the exploration of the ignored in the imperial historiography Lithuanian element and the national division of one undivided "Russian" history into two independent - Belarusian and Ukrainian. In other words, instead of the imperial, "supranational" narrative, a call for the writing of the national narratives about the Grand Duchy of Lithuania is clearly seen here. Such an approach was typical of the times of the patriarch of the Ukrainian historiography. It was adopted by the Ukrainian and Belarusian historiographies in the 1920s, the times of implementing the Soviet localization policy, but again rejected by the party

28 Грушевський М.С. Звичайна схема «русскої» історії й справа раціонального укладу історії східного слов'янства. Український історичний журнал. 2014. № 5. С. 205-206. 
historical science of the USSR starting from the 1930s, which practically revived the imperial historical scheme.

How can the persistence of Malynovskyi's "imperial" position, which he held at least till 1918, the time of the last publication of his "Lektsii po istorii russkoho prava" (The Lectures on the History of the Russian Law), be explained? It is obvious that such conformism was not a wonder. Both M. Vladymyrskyi-Budanov, who (together with Fedir Leontovych) formulated the main school principles and whom O. Malynovskyi always respected and considered to be his teacher ${ }^{29}$, and the imperial historiographic culture, criticized by M. Hrushevskyi in the abovementioned article, and ethnopolitical loyalties of "pre-revolutionary" O. Malynovskyi pushed their way around. At least till the beginning of the 1920 s, he was a typical "little Russian", in other words, a person with the "all-Russian" political and cultural awareness, which, however, sympathized with its small Motherland. On the one hand, he considered himself to be of "Ukrainian origin" and gladly sang Ukrainian songs. Having married, his young wife embroidered him a Ukrainian shirt, which he treasured a $\operatorname{lot}^{30}$. O. Malynovskyi was married to the daughter of the leading figure of the Ukrainian movement of that time Oleksandr Konysky named Mariia. Being a part of Denikin's civilian government for a certain period of time in 1919, he contributed to the preservation of the Ukrainian Academy of Sciences, which chauvinists-denikinists wanted to $\operatorname{close}^{31}$. In the letter to the first president of the All-Ukrainian Academy of Science Volodymyr Vernadskyi in 1919, one of the well-known representatives of the school of "Western-Russian" law Fedir Tarnovskyi wrote about O. Malynovskyi as of "a genuine Ukrainian", "innate little Russian and Russian", opposing him to one of the scientists of Polish origin ${ }^{32}$. On the other hand, starting from 1898, he was beyond the public and political life of Ukraine under Russian control. He was an active member of the allimperial Kadet Party, which took a moderate stance on the Ukrainian question. At the Kadet Party congress in Yekaterinodar in 1918, he voted in favour of the resolution on one and indivisible Russia ${ }^{33}$. This step was not accidental. Malynovskyi's diary entries confirm that his position was

29 Див: Малиновский И.А. Памяти учителя (Опыт характеристики ученой и преподавательской деятельности профессора М.Ф. Владимирского-Буданова). Острог, 2013. 58 с.

${ }^{30}$ Морозова О.М. Нарратив профессора И.А. Малиновского. Матеріали II Міжнародної науковопрактичної конференції «Малиновські читання», м. Острог, 15-16 листопада 2013 року. Острог, 2013. C. $26-27$. C. 51 .

31 Яремчук В. Призабуті постаті української історіографії: біоісторіографічні нариси. Острог, 2002.

32 Фоминых С.Ф., Некрылов С.А., Афанасенков В.О. Несколько дней из жизни академика И.А. Малиновского (по материалам Ейского дневника 1928 г.). Матеріали III Міжнародної науковопрактичної конференції «Малиновські читання», м. Острог, 14-15 листопада 2014 року. Острог, 2014. С. 28.

${ }^{33}$ Морозова О.М. Нарратив профессора И.А. Малиновского. С. 27. 
genuine. For example, in his Yekaterinodar diary on January 1, 1920, he wrote that he made a New-Year's toast to the revival of Russia: "I [...] proposed a toast to the mutual family - to Russia; I wished that the New Year was new in all senses, that all the nightmares and horrors of our lives left along with the old year, that our miserable, exhausted, torn to pieces and tarnished Motherland revived, that we became free citizens of united great Russia in the New Year" ${ }^{34}$.

However, during the "Kyivan" period, we observe the metamorphoses of the scientist's works, which were not only "scientific". Firstly, we can see certain "Marxist" accents, particularly the elements of the materialistic understanding of the historical process typical of Marxism in his works. Yes, in the review of Taranovskyi's book "Vvedeniye $\mathrm{v}$ istoriyu slavianskoho prava" (The Introduction into the History of Slavic Law) (1922) in 1927, he highlighted that "the law is a result of social and economic conditions" 35 . In his work "Revoliutsiine radianske zvychaieve pravo" (The Revolutionary Soviet Customary Law) (1928), O. Malynovskyi was writing the following: "It is known that the law is created on the social and economic basis, that this basis changes along with the increase in the creative power, and thus, the law changes, and that the legal rules, in which the law manifests itself in every historical epoch, protect the interests of the dominant under the social and economic

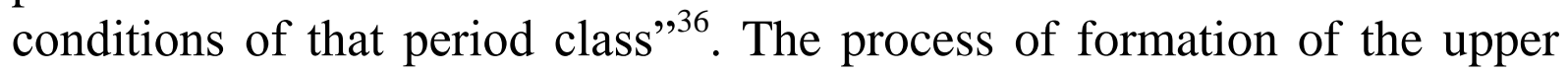
class through the lens of Marxism is depicted in the work "Starodavnii derzhavnyi lad skhidnych slovian ta yoho piznishi zminy. Narysy z istorii prava" (The Ancient System of Government of the Eastern Slavs and its Later Changes. Sketches on the History of Law) (1929) (which we will discuss later): "The political order is a reflection of the social and economic order due to the state of the national economy. The seeds of distinguishing an influential minority are already seen in primitive times. However, even in the epoch of accumulative economy and primitive communism, factual differences existed and had weight [...]. With time, when the private property and the class structure of society appears, the distinction of the wealthy minority and its dominant role are imminent. At the same time, the wealthiest who is a natural representative and a leader of this minority as well as of all people who are unwillingly under his control and exploited by him"37 stands out. In his book "Radianski popravcho-

\footnotetext{
${ }^{34}$ Ibid. C. 26.

${ }^{35}$ Михальченко С.И. Киевская школа в российской историографии. С. 112.

36 Малиновський О.О. Революційне радянське звичаєве право. Праці комісї для виучування звичаєвого права України. Київ,1928. Вип. 3. С. 122.

${ }^{37}$ Малиновський О. Стародавній державний лад східніх слов'ян і його пізніші зміни: Нариси 3 історії права. Київ, 1929. С. 32.
} 
trudovi ustanovy porivniuiuchy z burzhuaznymy tiurmamy" (The Soviet Corrective-Labour Establishments in Comparison with the Middle-Class Prisons) (1928), the following statement looks completely Marxist: "Crimes are committed because of social and, in the long run, economic conditions" 38 .

It is impossible to be completely sure about how genuine and organic the elements of the Marxist methodology, used by O. Malynovskyi in his works of the "Kyivan" period of life, were for him. It is obvious that just like the majority of the representatives of the old academia, his "Marxist" statements were more or less forced because this doctrine was declared official by the new government. On the other hand, his diary notes of this period show that the historian quite seriously perceived and positively assessed the social transformations, which were taking place in the Soviet Union and Ukraine in the 1920s. However, he was critical of the specific situations, for example, the insufficient attention of the government to the problems of science, the interference of bureaucracy in the scientific life, cronyism in the All-Ukrainian Academy of Science, etc. Rejecting many modern to him processes and phenomena, he, as it seems, placed much hope in the Soviet order at least till 1928. For instance, explaining two social and political systems, where he used to live, bourgeois and Soviet, in August of 1928, he wrote that "the idea of the mutual assistance is provided to the highest degree, and the possible mistakes of one person are rectified thanks to the experience of others" 39 in the Soviet system. In his notes of the "Kyivan" period, we find another important speculation: "Nowadays the protests are not necessary. What goes beyond the wildest expectations has come to pass" 40 . Thus, it is possible that his "Marxist" statements were coming not from the banal opportunism (which is difficult to believe knowing the bravery and civic position of the eternal opponent) but from the respect for the doctrine, which was presented in the USSR, and Malynovskyi's ideas and which in the process of its implementation was leading and should have led to a more democratic, fair public order. There was less than a year till the beginning of the "great" Stalinist "turnaround", which showed the illusory of the idealistic expectations of the professor, raised on the principles of respect for the value of human life...

We also note another metamorphosis of the intellectual face of "late" O. Malynovskyi. It seems that he felt a deeper connection with Ukraine.

\footnotetext{
${ }^{38}$ Малиновський О.О. Радянські поправчо-трудові установи порівнюючи з буржуазними тюрмами. Київ, 1928. С. 10.

39 Фоминых С.Ф., Некрылов С.А., Афанасенков В.О. Несколько дней из жизни академика И.А. Малиновского. С. 27.

40 Яремчук В. Призабуті постаті української історіографії. С. 52.
} 
The reason for it was his commitment to the scientific work of the leading scientific institution in Soviet Ukraine, which strengthened the selfawareness of $\mathrm{O}$. Malynovskyi as a Ukrainian scientist. His diaries show that he favourably evaluated the Bolsheviks' national politics, having seen a certain form of Ukrainian sovereignty among its consequences: "Ukraine is not the same as before: it is not "an inseparable part of United Russia", but an independent, free state - "the Ukrainian Soviet Republic" ". Such ideas were not unusual in the period of Ukrainization. A number of Ukrainian figures also took a rose-coloured view of the Bolsheviks' national reform, perceiving the USSR as Piemonte of the national rebirth. Let us remind at least the textbook fact about the emigration of 70,000 Galician Ukrainians to Soviet Ukraine in the 1920s .

From this perspective, a partial transformation of Malynovskyi's conceptual representations about the Eastern Slavic history is understandable. The last significant scientific text of the scientist was destined to become a synthesis "Starodavnii derzhavnyi lad skhidnikh slovian i yoho piznishi zminy: "Narysy z istorii prava" (The Ancient Government System of the Eastern Slavs and its Later Changes. Sketches on the History of Law). The book can be seen as an original "swan song", the result of Malynovskyi's historical and law studies. To some extent, this generalization interprets his previous texts in a new way. O. Malynovskyi suggested a new vision of the development of the state institutions of the Eastern Slavs from the pre-Kyivan period till the end of the 16 century. On the one hand, the historian repeated the old idea of the school of "Western-Russian" law about the triarch structure of the state system of Kyivan Rus and kept track of the development of this structure in the lands-principalities, which appeared after its disintegration. As in his earlier texts, in this one O. Malynovskyi argues that this genesis happened as follows: in Volhynia and Galicia, later Galicia-Volhynia principalities; in the Grand Duchy of Lithuania, the priority of the aristocratic element of power was established; in Novgorod the Great - at first the combination of aristocratic and democratic elements, where the latter gradually transformed into "fiction" as a result of social differences and the increase of the role of the boyardom, the aristocratic element gained the upper hand; in Muscovy, the monarchic order, which evolved from the monarchy, the limited Boyar Duma and zemsky sobors to absolutism, which firmly established itself at the beginning of the 18 century, won.

\footnotetext{
${ }^{41}$ Ibid.
} 
As we know, only one highly critical review of the academician's generalized work appeared ${ }^{42}$. Its author, the legal historian Viktor Novytskyi made a number of both appropriate and doubtful comments (for example, about the author's complete disregard for the Ukrainian historiography (when O. Malynovskyi cited "Istoria Ukrainy-Rusy" (The History of Ukraine-Rus) by M. Hrushevskyi several times, argued with the views of V. Antonovych on the Council of Lords in the Grand Duchy of Lithuania $^{43}$ ), the exaggeration of the democracy in Novgorod (when O. Malynovskyi stated that the Novgorod democracy started falling from the 13 century, and the factual power was given to duma ${ }^{44}$ ), disregard for the role of the boyardom in Suzdal (instead, the scientist noted that Moscow rulers "had to put up with the organized participation of the boyardom in the governance in the form of the Boyar Duma" till the beginning of the 13 century $^{45}$ ). At the same time, the reviewer did not notice a very important statement of Malynovskyi's last book. The point at issue here is that in it O. Malynovskyi, in fact, supported the views of M. Hrushevskyi on the question of the origins of the Russian people and the Russian state. According to O. Malynovskyi, the Great Russian nation "emerged from the combination of the Slavic and Finnish elements" after the emigration of "the Rus people" to the east and north in the times of crisis of Kyiv and southern Rus in the second half of the 12 century. The academician of the All-Ukrainian Academy of Science started the genesis of Muscovy from the Suzdal (Rostov-Suzdal) land, which he called the colony of Novgorod the Great and which, according to him, became an independent principality at the beginning of the 12 century. "The Suzdal land was the seed that produced Muscovy", stated O. Malynovskyi ${ }^{46}$. Thus, we see that O. Malynovskyi accepted the main thesis of Hrushevskyi's scheme regarding the necessity to differentiate the history of the Ukrainian people and forms of their governmental organization from the history of other Eastern-Slavic people and states. It is obvious that apart from the above-mentioned factors, the important role in it was also played by the general readiness of the Ukrainian historians of the 1920s for the criticism of the traditional great-power view on the history of the Eastern Slavs, which, with some modifications, the Russian historians of the postrevolutionary epoch, including the new generation of the historiansMarxists, continued to support. It is known that despite a difficult,

\footnotetext{
${ }^{42}$ Новицький В. [рец. на:] Малиновський О. Стародавній державний лад східніх слов'ян і його пізніші зміни: Нариси з історії права. Київ, 1929. Україна. 1930. № 40. С. 143-151.

${ }^{43}$ Малиновський О. Стародавній державний лад східніх слов'ян і його пізніші зміни. С. 71.

${ }^{44}$ Ibid. C. $114-116$.

${ }^{45}$ Ibid. C. 151.

${ }^{46}$ Ibid. C. 126-127.
} 
sometimes hostile, attitude towards M. Hrushevskyi, his fierce critics from the camp of the Ukrainian historians-Marxists headed by Matvii Yavorskyi recognized the accuracy of Hrushevskyi's scheme regarding the EasternSlavic past.

It is noteworthy that during his days at the All-Ukrainian Academy of Science, O. Malynovskyi emphasized the necessity of the early development of the complete course of the history of the Ukrainian law as an independent academic discipline to the scientific community on several occasions. In the 1920s, thanks to the researches of Mykola Vasylenko, Mykhailo Slabchenko, Mykola Chubatyi, Rostyslav Lashchenko, etc., the establishment of this branch of the historical and legal science was taking place. O. Malynovskyi not only supported the very idea of separation of the history of the Ukrainian law as an independent academic discipline but also joined the discussion about its subject. Unlike M. Chubatyi, O. Malynovskyi (as well as his work colleague in the All-Ukrainian Academy of Science Lev Okynshevych) demanded that the course of the history of the Ukrainian law included also the "foreign", nationally nonUkrainian law, adopted or imposed upon the Ukrainian people, and that the name of the discussed discipline was "the history of the law of the Ukrainian people" and not "the history of the Ukrainian law" $"$. Therefore, in this discussion, he revealed himself as a Ukrainian scientist and a legal historian, who, considering the frequent presence of Ukrainians on the territory of non-Ukrainian ethnic groups and states, looked at the Ukrainian history and the history of the Ukrainian law from both territorial and narrow national perspectives.

\section{CONCLUSIONS}

Thus, at the end of his life, in the conditions of socio-political and intellectual changes of the period of revolutions at the territory of the Romanov state and "red Renaissance" in the 1920s, which resulted in the birth of Ukraine as a national and political reality, a typical "little Russian" historian, which took an imperial historical stance (it did not see any differences in the historical destiny of different "branches" of "Russian" people and was "supranational" in this context) gradually "grew into" the Ukrainian cultural context. The example of O. Malynovskyi is unique in some way. The majority of the pre-revolutionary historians, who started to serve Ukraine in the relatively liberal 1920s, produced "the golden age" in the Ukrainian historical science in the Bolsheviks' USSR, marked their

47 Малиновський О. Курс історії права українського народу (з приводу «Лекцій по історії українського права» Р. Лащенка, професора Українського Університету в Празі). Пращі комісї для виучування історії західньо-руського та вкраїнського права. Київ, 1927. Вип. 3. С. 12-13. 
belonging to the Ukrainian intellectual process and the national movement back in the pre-revolutionary period. Among the most famous ones is Dmytro Bahlii, the transformation of whom from the official imperial cultural figure into the leading Ukrainian historian was rapid and painless. He was like that even before 1917. However, due to his conformism, he was thoroughly hiding his Ukrainian self-awareness.

\section{SUMMARY}

The article attempts to explain the reasons and demonstrations of the historical thought of the researcher of the legal history of the Grand Duchy of Lithuania Onykii Malynovskyi (1868-1932). The author reaches the conclusion regarding the gradual migration of the scientist from the supranational Russian imperial historiographic culture to the national Ukrainian one. The reasons for such changes lie in the integration of the scientist into the context of the scientific and public life of the Soviet Ukraine of the period of Bolsheviks' Ukrainization, possible growth of his Ukrainian ethnonational fealty. The national reform in Ukraine led to the national and cultural uprise ("the red Renaissance") and the spread of the national self-awareness among the intellectuals. These common processes touched O. Malynovskyi as well.

\section{REFERENCES}

1. Бондарук Т. Західноруське право: дослідники і дослідження (Київська історико-юридична школа). Київ, 2000. 160 с.

2. Василенко М. Передмова. Праці комісії для виучування історії західньо-руського та вкраӥнського права. Київ, 1925. Вип. 1. С. III-IX.

3. Владимирський-Буданов М. Рада Великого Князівства Литовського. Записки соціально-економічного відділу [УАН]. Київ, 1926. T. IV. C. 204-237.

4. Грушевський М. С. Звичайна схема “русскої” історії й справа раціонального укладу історії східного слов'янства. Український історичний журнал. 2014. № 5. С. 203-208.

5. Малиновский И.А. Лекции по истории русского права. Москва, $2015.696 \mathrm{c}$.

6. Малиновский И.А. Памяти учителя (Опыт характеристики ученой и преподавательской деятельности профессора М.Ф. Владимирского-Буданова). Острог, 2013. 58 с.

7. Малиновский И. Лекции по истории русского права. Ростов-наДону, 1918. 497 с. 
8. Малиновский И. Рада Великого княжества Литовского в связи с боярской думой древней России. Томск, 1903. Ч. I: Боярская дума древней России. IV, 201 с.

9. Малиновский И. Рада Великого княжества Литовского в связи с боярской думой древней России. Томск, 1904. Ч. II: Рада Великого княжества Литовского. Вып. 1. IV, 132 с.

10. Малиновский И. Рада Великого княжества Литовского в связи с боярской думой древней России. Томск, 1912. Ч. ІІ: Рада Великого княжества Литовского. Вып. 2. (1492-1569). 492 с.

11. Малиновский И. Учение о преступлении по Литовскому статуту. Киев, 1894. 232 с.

12. Малиновський О. Курс історії права українського народу (з приводу “Лекцій по історії українського права" Р. Лащенка, професора Українського Університету в Празі). Праці комісії для виучування історї західньо-руського та вкраїнського права. Київ, 1927. Вип. 3. С. 1-13 [окрема відбитка].

13. Малиновський О.О. Радянські поправчо-трудові установи порівнюючи з буржуазними тюрмами. Київ, 1928. 227 с.

14. Малиновський О.О. Революційне радянське звичаєве право. Праці комісії для виучування звичаєвого права Украӥни. Київ, 1928. Вип. 3. С. 114-212.

15. Малиновський О. Стародавній державний лад східніх слов'ян і його пізніші зміни: Нариси з історії права. Київ, 1929. 186 с.

16. Михальченко С.И. Киевская школа в российской историографии (Школа западно-русского права). Москва; Брянск, 1996. 186 с.

17. Морозова О.М. Нарратив профессора И.А. Малиновского. Матеріали II Міжнародної науково-практичної конференції “Малиновські читання”, м. Острог, 15-16 листопада 2013 року. Острог, 2013. С. 17-32.

18. Новицький В. [рец. на:] Малиновський О. Стародавній державний лад східніх слов'ян і його пізніші зміни: Нариси 3 історії права. Київ, 1929. Україна. 1930. № 40. С. 143-151.

19. Сборник материалов, относящихся к истории панов-рады Великого княжества Литовского. Томск, 1901. 693 с.

20. Сборник материалов, относящихся к истории панов-рады Великого княжества Литовского. Добавление. Томск, 1912. 139 с.

21. Фоминых С.Ф., Некрылов С.А., Афанасенков В.О. Несколько дней из жизни академика И. А. Малиновского (по материалам Ейского дневника 1928 г.). Матеріали III Міжнародної науковопрактичної конференції "Малиновські читання", м. Острог, 14-15 листопада 2014 року. Острог, 2014. С. 26-35. 
22. Яремчук В. Призабуті постаті української історіографії: біоісторіографічні нариси. Острог, 2002. 165 с.

23. Kappeler A. Russland und die Ukraine: verflochtene Biographien und Geschichten. Wien; Köln; Weimar, 2012. 395 s.

\section{Information about the author:} Yaremchuk V. P.

Ph D hab. (History), Professor, Professor at the Department of History, National University of Ostroh Academy 2, Seminarska str., Ostroh, Rivne region, 35800, Ukraine 
NOTES 
NOTES 
Publishing house "Liha-Pres"

9 Kastelivka str., Lviv, 79012, Ukraine

44 Lubicka str., Toruń, 87-100, Poland

Printed by the publishing house "Liha-Pres"

Passed for printing: September 17, 2019.

A run of 150 copies. 